Prisoners' Rights and Media Wrongs:

\title{
A Critical Discourse Analysis of the Media Representation \\ of Private Prisons in New Zealand
}

By

Otis Lynch Boyle

\begin{abstract}
A thesis
submitted to Victoria University of Wellington

in fulfilment of the requirements for the Degree of

Master of Arts in Criminology
\end{abstract}

Victoria University of Wellington

December 2016 
For those imprisoned, not least my friend Alex. 


\begin{abstract}
In 2009, the Corrections (Contract Management of Prisons) Amendment Bill was passed, implementing the New Zealand (NZ) Government's policy of prison privatisation. Subsequently, 'Mt Eden', a public prison previously managed by the state, was contracted to British conglomerate Serco and a second private prison, 'Wiri', was built under contract to the same company. However, in July 2015, a cell-phone video capturing Mt Eden prisoners engaged in fights, in full view of prison officers and CCTV, was uploaded to YouTube. It captured the attention of the media, politicians and the public. An unprecedented stream of media revelations about prisoner mistreatment, corruption and various human rights violations followed, prompting the Department of Corrections to seize control of the prison. In the wake of this 'crisis', this thesis explores the changing nature of legitimacy for private prisons in NZ. Where previously, legitimacy of the penal system was largely staked on security and maintaining sufficiently austere prison conditions, the revelations of serious rights violations at Mt Eden prison highlights one of the 'moments' in which the legitimacy of the prison system was fractured for being too severe.
\end{abstract}

To examine the changing nature of legitimacy, the study investigates the treatment of private prisons by three media sources - the New Zealand Herald, Stuff and Radio New Zealand. It uses framing, critical discourse and source analysis, with the aim of exploring how dominant penological discourses operate to protect and sustain the prison system in the face of a human rights scandal. The thesis separates analysis into two critical periods: after the introduction of private prisons in 2009; and after the release of the YouTube videos. A managerial frame is consistently found across the news outlets alongside a source bias towards mainstream politics and corporate interests. Before the human rights scandals, the focus on how to deliver punishment, rather than the state's obligations to those it incarcerates or wider social goals, established the legitimacy of private prisons under the banal everyday discourses of managerialism. While humanitarian framing increased substantially after the human rights scandals, these were subsumed under the frames of managerialism, security and less eligibility. These frames acted to depict the prison crisis as an unfortunate individual aberration of security that could be managed through a government response. In short, the legitimacy of the prison remained intact and was, ultimately, strengthened. 


\section{ACKNOWLEDGEMENTS}

First, I owe my greatest debt of gratitude to my supervisor, Lizzy Stanley. There is no way I could have completed this thesis without your patience and guidance over the past year, not to mention the generous scholarship as part of the Rutherford Discovery Fellowship. The timely and exhaustive feedback on the numerous less-than-lucid drafts proved invaluable.

I was fortunate enough to receive substantial financial support this year. Victoria University's Master's Scholarship allowed me to comfortably study full-time towards my MA. More generally, I owe thanks to the Trustees of the Terry Boyle Memorial Trust, whose assistance over the last six years has been essential to my academic success.

The School of Social and Cultural Studies at Victoria have been instrumental during my undergraduate and postgraduate study. I was lucky to have been given an early opportunity to undertake bona fide peer-reviewed research with Fiona Hutton and Trevor Bradley provided early guidance and fostered my enthusiasm during my Honours year.

Finally, Dad thanks for the roasts and Mum thanks for the lunches. 


\section{LIST OF TABLES AND FIGURES}

Figure 1: Total sample of articles in Stuff, New Zealand Herald and Radio New Zealand from 01 March 2009 to 01 March 2016 37

Figure 2: Total Sources by category in Stuff, New Zealand Herald and Radio New Zealand from 01 March 012009 to 30 June 2015. .47

Figure 3: Total Party Political representation in Stuff, New Zealand Herald and Radio New Zealand combined from 01 March 2009 to 30 June 2015 .48

Figure 4: Total Sources by category in Stuff, New Zealand Herald and Radio New Zealand from 01 July 2015 to 01 March 2016. .66

Figure 5: Total Party Political representation in Stuff, New Zealand Herald and Radio New Zealand combined from 01 July to 01 March 2016. 67

Table 1: News source categories.

Table 2: Primary Frame Categories. .44

Table 3: Primary News Frames in Stuff, New Zealand herald and Radio New Zealand from 01 March 2009 to 30 June 2015. .51

Table 3: Primary Frames in Stuff, New Zealand herald and Radio New Zealand from 01 July 2015 to 01 March 2016. .69 


\section{CONTENTS}

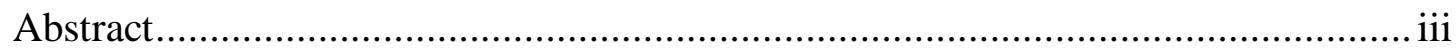

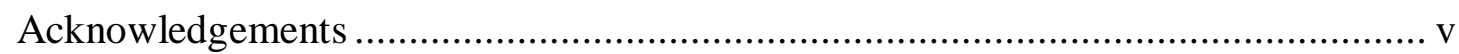

List Of Tables And Figures ................................................................................ vi

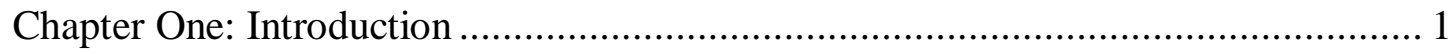

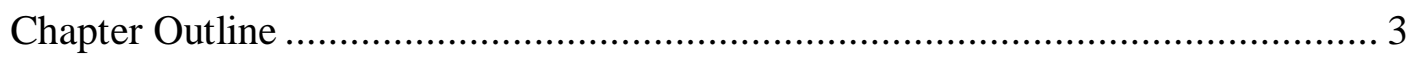

Chapter Two: The Legitimacy Problem .............................................................. 6

Penal Legitimacy: A Dialogic Approach....................................................... 7

The Power Of Scandal .................................................................................. 10

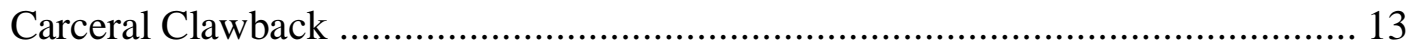

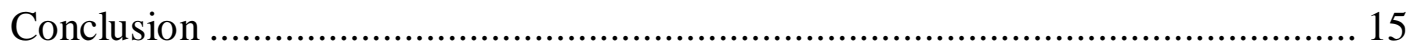

Chapter Three: Competing Discourses............................................................ 17

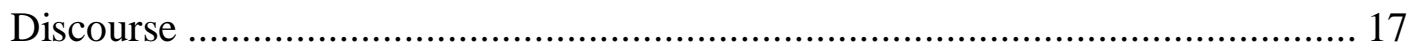

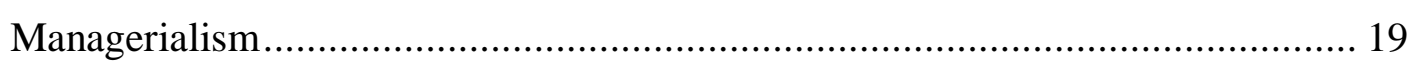

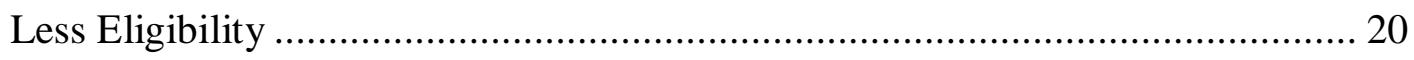

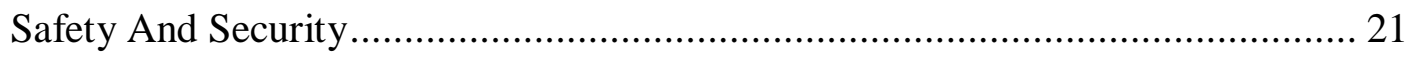

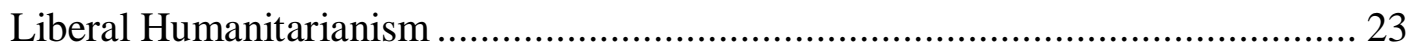

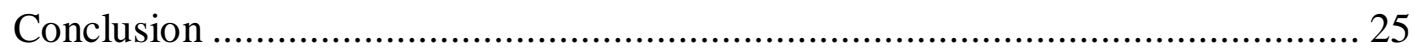

Chapter Four: Media And The Production Of 'Truth' ......................................... 27

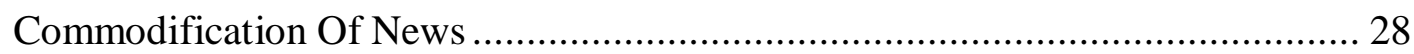

The Role Of 'Experts' ................................................................................ 30

Prisons And The Politics Of Pity .................................................................. 32

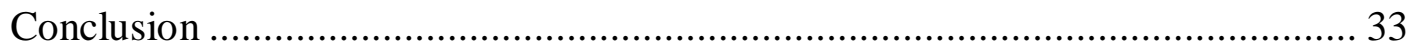

Chapter Five: Methodology And Methods ........................................................ 36

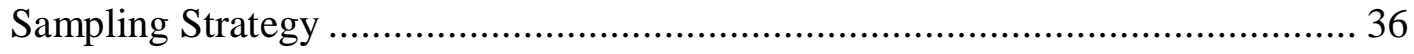

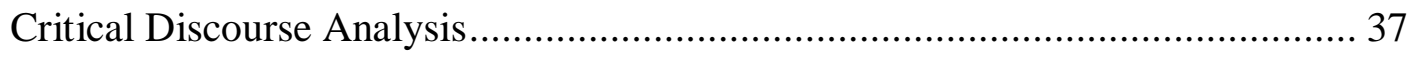

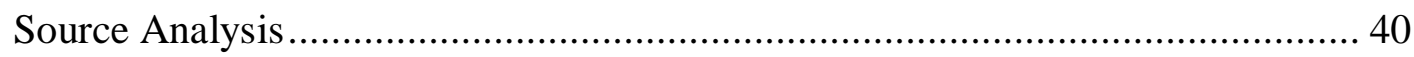

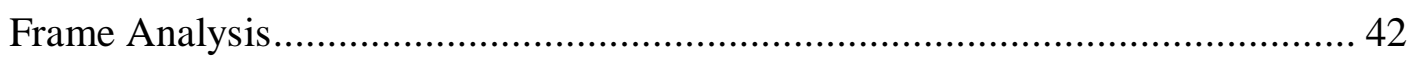

Summary And Conclusion................................................................... 45

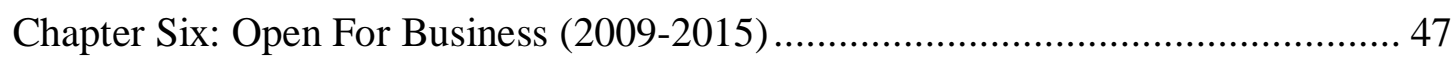

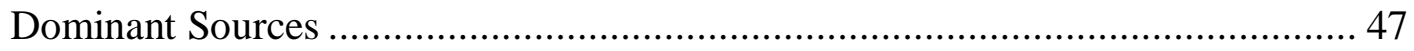

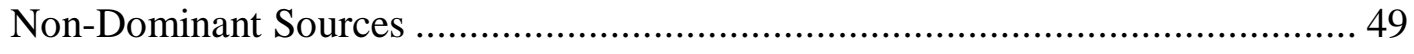

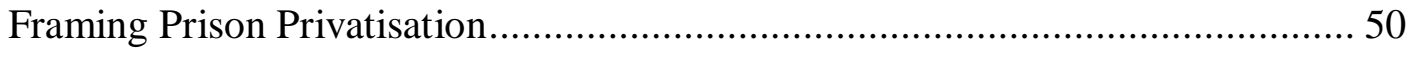

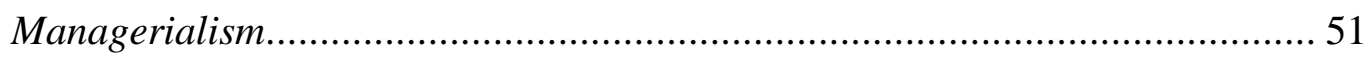

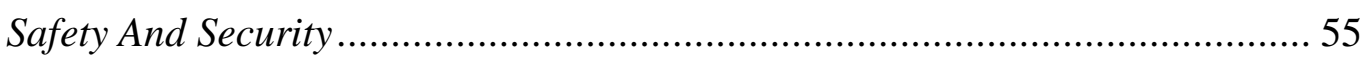

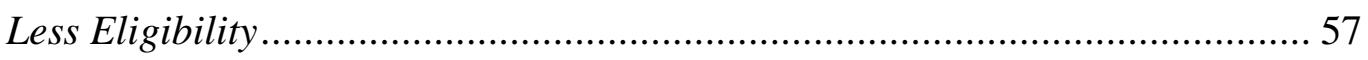


Politics 59

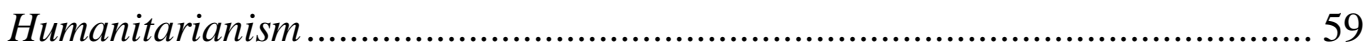

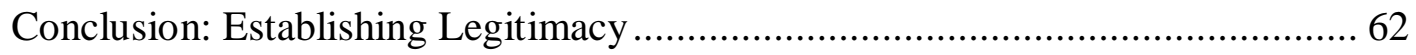

Chapter Seven: It's A Jungle, And Inside Are Animals (2015-2016) ....................... 65

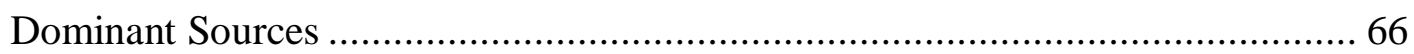

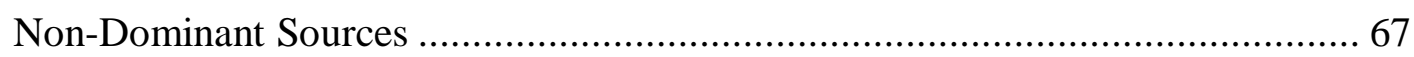

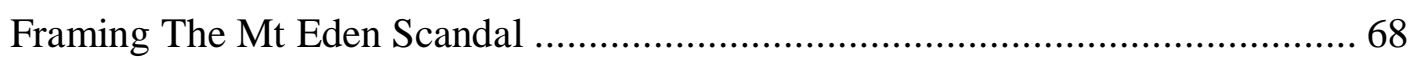

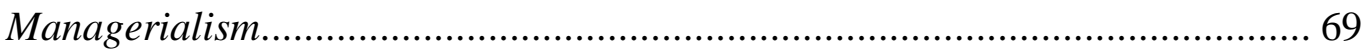

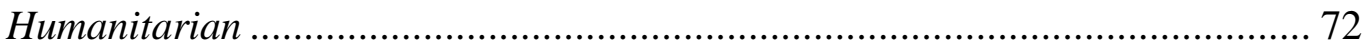

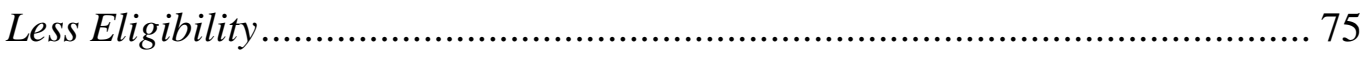

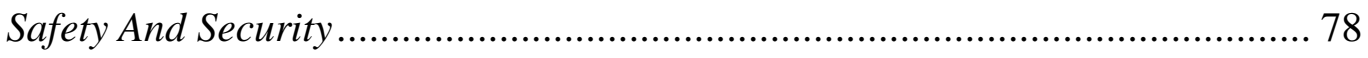

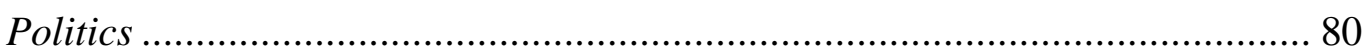

Conclusion: Re-Establishing Legitimacy ................................................. 81

Chapter Eight: Discussion And Conclusion ...................................................... 84

Journalism And The Power Of The Image ........................................................ 87

Official Investigation Of The Chief Inspector .................................................. 88

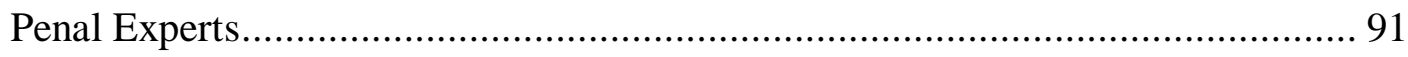

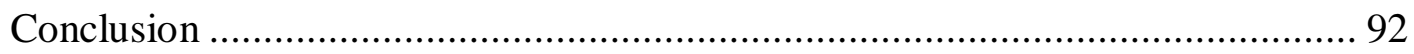

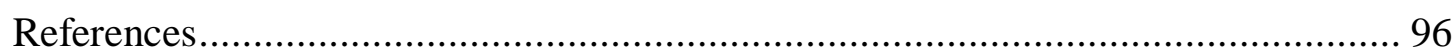




\section{CHAPTER ONE: INTRODUCTION}

Historically, incarceration in New Zealand (NZ) has been the sole responsibility of the government. Although the modern state engaged private sector involvement in community service provisions, it still came as a surprise that privatisation took hold in the penal sector. Upon re-election in 2008 the National government revived their private prison policy and in March 2009 tabled the Corrections (Contract Management of Prisons) Amendment Bill. An overwhelming number of submissions to the Law and Order Committee opposed privatisation, citing concerns with human rights, corruption of justice, and the proper function of the state (Amnesty International Aotearoa NZ, 2009; Corrections Association of NZ, 2009; Howard League for Penal Reform, 2009; Human Rights Commission, 2009; Justice Action, 2009; Kelsey, 2009; Leadbeater, 2009; Movement for Alternatives to Prison, 2009). Jim Gladwin (2009, p. 1), for example wrote that, because privatisation was not acknowledged during the election, he regarded "the legitimacy of mandate as suspect and the electoral process is degraded as a consequence." Some critics argued that imprisonment is an intrinsic state function that cannot be delegated without undermining the legitimacy of the state. For example, the Human Rights Commission (2009, p. 2) wrote:

When the state deprives a person of his or her liberty it assumes a solemn duty to ensure the safety of that person, given that they have been deprived of the means of doing so for themselves. This is a responsibility that rests with the state and is one by its very nature that cannot be "contracted out".

For other critics, profiting from imprisonment corrupts the idea of justice and increases the potential for human rights violations. Amnesty International Aotearoa NZ (2009, p. 4) cited human rights obligations under international and domestic law, arguing that "privatising prisons will necessarily remove elements of accountability in this core public function and as such have potential to constitute a fundamental breach of these obligations".

The four submissions that supported the Bill (G4S Australia Pty Ltd, 2009; GEO Group Australia Pty Ltd, 2009; Ngā Whetü Rererangi, 2009; Trewavas, 2009) relied on three distinct arguments. G4S Australia Pty Ltd (2009, p. 3), a company that manages private 
prisons in Australia, wrote that the motive of privatisation could "reform and improve an ageing and increasingly discredited prison system through competition and efficiency gains" and cited the "substantial savings" that privatisation offers governments. Peter Trewavas (2009, p. 1) emphasised the deterrent prospects of austere prisons, writing: "hopefully privately run prisons, in the interest of returning a profit, will return prison life to the good old days of a Spartan cell (bunk, washbasin, toilet) and 3 square meals a day of bread and water". In stark contrast, Ngā Whetü Rererangi (2009, p. 2), while recommending amendments to the original Bill, hoped that contracting prisons would provide opportunities for "Māori to provide solutions to Māori issues of reoffending".

Reflecting the managerial rhetoric of cost efficiency and service delivery, the Corrections (Contract Management of Prisons) Amendment Bill was passed in December 2009 and the tender for Auckland Central Remand Prison was subsequently granted to the British conglomerate Serco. Over the following five years, and with the construction of an additional private prison, the success of private prisons were lauded by the government for "outperforming most public prisons in league tables" (Davison, 2013, March 27) and offering innovative rehabilitation, employment, and education programmes (S. Collins, 2015, May 06).

However, in 2015, a video was uploaded to YouTube showing organised prisoner 'fight clubs' in full view of prison officers and CCTV of the privately managed Mt Eden prison (Tait, 2015, July 18; Walters, 2015, July 16). The following months involved a number of revelations on the mistreatment of prisoners and Serco's subsequent attempts to avoid reporting violent incidents to the government: Labour minister Kelvin Davis alleged that a prisoner, Alex Littleton, had died after he was subject to an initiation called "dropping", in which prisoners are thrown from balconies (Moir, 2015, July 24); an unnamed prisoner claimed he was transferred after an assault in Mt Eden prison, so his injury would not be linked to the Serco prison (Fisher, 2015, August 28); Corrections Associated President Bevan Hanlon accused Serco of under-reporting assaults at Mt Eden prison (Christian, 2015, September 03); two prisoners committed suicide after being subject to violent bullying (Loren \& Wall, 2015, July 26); Mt Eden prisoners were among ten Head Hunter gang members arrested for involvement in smuggling contraband into the prison (Leask, 2015, July 29); staff were dismissed after 
they gave 'sparring advice' to prisoners (N. Jones, 2015, August 26); a French national who had been incarcerated in Mt Eden prison was admitted to intensive care after he was beaten with a pool cue (Cowlishaw, 2015, August 30); and, it was discovered teenage remand prisoners were being locked in their cells for 23 hours of the day (RNZ, 2015, December 03).

The general public largely rely on the mass media for information related to the prison and those incarcerated (M. Brown, 2013; Cheliotis, 2010; Mason, 2006; Riches, 2014). The media has an important role in circulating narratives that lead to a sense of 'scandal' (J. B. Thompson, 2000). The Mt Eden scandals had strong audience appeal: immediacy, drama, personalisation and continuing novelty. Further, the video evidence, Stuff wrote, invited "the public into a major prison" (N.A., 2015, July 22), and gave authenticity to what might otherwise not have been acknowledged. The atypical prominence of prisoner treatment in the media carried the threat for renewed public controversy over the legitimacy of prison privatisation and prisoners' human rights. This 'critical discourse moment" (Chilton, 1987, p. 12) provides a unique opportunity to study the limits of penal severity, the techniques and strategies of legitimacy management by the prison system, and the popular construction of prisoners' rights in NZ.

Against this backdrop, the two main purposes of this thesis are: (1) to analyse the prominent discourses of prisoners' human rights in NZ, and (2) to examine the changing nature of penal legitimacy for private prisons. This will be examined by conducting a framing, source, and critical discourse analysis of three national news outlets coverage of prison privatisation between 2009 and 2016. While analysing the discourse following the Mt Eden scandal is the main focus, it is also important to examine how private prisons and prisoners' rights are discussed in the absence of a scandal, and how usually banal penological discourses shape and restrict the boundaries within which any scandal is later discussed.

\section{Chapter Outline}

The following chapter two begins with a justification of the use of legitimacy as a lens for the current research. Legitimacy, the "perception or assumption that the actions of an entity are desirable, proper, or appropriate within some socially constructed system of norms, values, beliefs and definitions" (Suchman, 1995, p. 574), is central to 
people's acceptance of institutions and authorities (Beetham, 1991; Weber, 1978). Despite the many scandals that have plagued the prison system, (Carlen, 2002a, p. 115) has noted the uncanny ability of the prison to evolve, defend and neutralise critique through, what she calls, "carceral clawback". This chapter outlines the dialogical approach to legitimacy, followed by factors that create, sustain and undermine the legitimacy of the prison.

Borrowing largely from David D. G. Scott (2009), chapter three examines the main penologies of prisoners' rights in NZ. Locating the discussion within Foucault's notion of discourse, the chapter outlines the main principles of managerialism, lesser eligibility, safety and security, and humanitarianism. These four penologies provide the template for understanding how the media conceptualise and legitimise the experience of imprisonment and prison privatisation.

Despite extensive research on the media and imprisonment, there remains considerable scope for the development of a critical analysis on the media's role in legitimacy management. Chapter four considers the literature on the "mediation of suffering" (Boltanski, 1999; Chouliaraki, 2006; Frosh \& Pinchevski, 2009; Kitch \& Hume, 2008; Sontag, 2003), which provides insights into the media coverage of suffering at a distance. I take this literature as a point of departure, emphasising the social and cultural distance between the NZ prison and the NZ public.

Before the results, chapter five outlines the methodological approach for this research analysis of media discourses. Before briefly outlining the sampling strategy and coding procedure, the chapter details source analysis, framing analysis and critical discourse analysis.

Building on previous discussions, the findings chapters (six and seven) discuss the content and significance of the different media frames around prison privatisation before and after the Mt Eden scandals. By relying on sources deemed authoritative, media coverage tended to "systematically echo the judgments and perspectives of the power elite" (Schiller, 1981, p. 123). Before the scandals in Mt Eden the three news outlets shared a common set of penological logics. The heavy dependence on a managerial frame manifested in a broadly positive evaluation of prison privatisation. While humanitarian framing increased substantially after the human rights scandals, 
these were subsumed under the frames of managerialism, safety and security and less eligibility, depicting the prison crisis as an unfortunate individual aberration of security that could be managed through a government response.

The final chapter eight, the discussion and conclusion, considers how the strategies of resistance were met and neutralised. The deeply embedded assumptions about prisoners facilitated the shift from literal denial of prisoner suffering to implicatory denial, in which the significance was dismissed. The report of the investigation Chief Inspector provides extra insight in to the link between power and discourse and the strategies of othering adopted by the state. Despite the resilience of the prison to critique and scandal, the media proves to be one of the most crucial institutions for holding prison authorities to account. 


\section{CHAPTER TWO: THE LEGITIMACY PROBLEM}

With the growth of the prison in NZ, the question of legitimacy has become increasingly central to discussions of criminal justice. Under certain conditions, Zimring and Hawkins (1994, p. 83) wrote, prison populations appear to have an "openended capacity for change". New Zealand most exemplifies the "social and legal deformities" (Simon, 2014, p. 24) that engender mass incarceration. John Pratt has traced the cultural values that provide the foundation for exclusion and intolerance (2006); the political and economic changes that provoked a sense of anxiety and insecurity (2005); the changing media landscape that contributed to the democratisation of penal expertise (2005); and the increasing centrality of risk management in crime control and punishment $(2016 ; 2015)$. The bipartisan deference to incarceration led to an unprecedented increase in the imprisonment rate after the 1980's. According to the most recent statistics from the Department of Corrections, the rate of imprisonment in NZ reached 260 per $100,000^{1}$ in 2015 , more than a $400 \%$ increase from the 60 per 100,000 in 1950; the daily average prison population increased from around 2700 in 1985 to 11,977 in 2015 (not including a daily 8,848 remand population); and the average length of imprisonment increased from 8 months to 18 months (Department of Corrections, 2016c).

Apart from the sheer scale of incarceration, the continuing failure of the prison to serve its purported aims sharpens the need for investigating the legitimacy of prisons (Dolovich, 2004). Indeed, for Sparks (1994, p. 26), the notion of legitimacy "delimits in large measure the very arena within which penological debate must take place." Scholars have shown that legitimacy is crucial to the maintenance of compliance with legal authorities, through what has been described as procedural justice (Tyler, 2006). A sense of legitimacy is vital to how communities and individuals engage with, and accept the power of, the police, courts and the prison (Liebling, 2004; Tyler, 2003). Given the inherently coercive nature of incarceration, legitimacy can be particularly difficult to foster with prisoners (Sparks, Bottoms, \& Hay, 1996).

Legitimating the prison is also challenging, given that prison authorities need to consider more than one audience (Bottoms \& Tankebe, 2012). Prisoners and the public

\footnotetext{
${ }^{1}$ Based on a population estimate of 4.6 million
} 
have distinct views about how prisons ought to be managed. The introduction of a private company to the relationship acts to further complicate the arrangement (Andrew, 2007; Cavise, 1998; Shichor, 1995, 1998). Bottom and Tankebe's (2012, p. 102) "dialogic approach" provides a framework to explore the establishment and management of the legitimacy of prisons in relation to different audiences. Assisted by the literature on organizational and institutional legitimacy (Suchman, 1995), the concept of legitimacy can reveal clues about the character of the prison in NZ, as well as the implications for the prospects of prisoners' rights. Previous work (Burkhardt, 2014; Crewe, Liebling, \& Hulley, 2014; Liebling, 2011; Pratt, 2008a) has identified several factors that undermines the legitimacy of the prison, even if not using the explicit language of legitimacy. Research has tended to emphasise the indignation directed at indulgence or insecurity rather than cruelty to prisoners (Pratt, 2008a; Sparks, 2000b; Sparks et al., 1996), and there is a considerable dearth of research into the moments that threaten the legitimacy of the prison for being too severe. The aim of this chapter is to provide a foundation for exploring the ascent and descent of private prison legitimacy and the moments in which prisoners' rights threaten the legitimate character of the prison.

\section{Penal Legitimacy: A Dialogic Approach}

The concept of legitimacy offers a unique approach to study the relationship between the prison system and the general public. Its power, Sparks (1994) argues, lies in the connections it can illuminate between the interior life of the prison and the external relationships which give authority to their conditions. A good deal of research indicates that the general public hold extremely punitive attitudes (see Pratt, 2008a). The most potent demonstration of public support for longer and harsher prison sentences, the Citizens Initiated Referendum in 1999, received 92 per cent support on the question: "Should there be a reform of the criminal justice system placing greater emphasis on the needs of victims, providing restitution and compensation for them and imposing minimum sentences and hard labour for all serious violent offences?" 2 However, research that explores public opinion beyond questionnaires indicates public perception

\footnotetext{
${ }^{2}$ It has been noted that the referendum question, designed by shopkeeper Norm Withers, involved an amalgamation of concerns for which voters could decide only yes or no (Pratt \& Clark, 2005). The overwhelming support likely captured a number of different concerns above simple punitive attitudes, such as distrust of the courts, the growing anxieties around crime, concerns for crime victims, and disenchantment with the existing democratic processes (Indermaur, 2008).
} 
of crime and appropriate responses are more nuanced than opinion polls or referendums indicate (Bradley, Rowe, \& Sedgwick, 2011). In NZ, research revealed that while crime was perceived to be a major national problem, the majority of people do not regard crime as a major problem in their local area, regardless of where they live (Bradley et al., 2011). Follow up interviews found that this was largely a result of the source of information about local and national issues. While people rely on personal experiences or relationships with neighbours, colleagues, friends or family for local crime trends, they tended to have no other source for national crime problems than the mass media.

This focus on public opinion or public mood speaks to Weber's (1978) approach to legitimacy, which emphasised the importance of gaining and maintaining public support. Criticizing the Weberian-inspired approaches to legitimacy, Beetham (1991, p. 8), asserted that a "given power relationship is not legitimate because people believe in its legitimacy, but because it can be justified in terms of their beliefs" (p. 11). Beetham outlined a three-dimensional framework of legitimate power. The first dimension, legality, refers to the exercise of power within the established rules of society, usually the law. The second dimension, relating to the core values of society, was the central point of contention with the Weberian approach. Not simply about the belief in the legitimacy of an authority, Beetham (1991, p. 17) argued that a system of power is legitimate "to the extent that the rules of power can be justified in terms of beliefs shared by both dominant and subordinate". Finally, an authority is legitimate only when gained and exercised under consent.

Beetham's (1991) tripartite framework provides half of the foundation for Bottom and Tankebe's (2012, p. 132) "dialogic approach" to legitimacy. The other half, "powerholder legitimacy" (p. 149), emphasises the importance of those in power actively maintaining legitimacy. Legitimacy is not simply conferred, it is partly a product of strategy and negotiation (Suchman, 1995). Drawing on Herbert's (2006) work on police legitimacy, Bottoms and Tankebe (2012, p. 149) argue that power-holder legitimacy is the result of authorities embracing the elements of: subservience to public needs; separation from the public; and being proactive in their duties, rather than only reactive. By drawing on the perspectives of audiences and power-holders, Bottoms and Tankebe emphasise the importance not just of the public's acceptance of authority, but of those 
in power believing they are servant to, and acting in accordance with, a larger collective goal.

At the everyday-level, prison staff and management behave with legitimacy in mind, striving to achieve balance between acting in a legitimate way and achieving control (Sparks, 1994; Sparks \& McNeill, 2009). As mentioned in the introduction, Liebling (2011) points to the importance of procedural justice for how prisoners engage with, and accept the power of prison authorities. However, prisons are uniquely coercive institutions and legitimacy in the prison is rarely a uniquely procedural issue (Sparks \& McNeill, 2009). Drawing on insights from the English prison system, Carrabine (2004) argues that, rather than resting on internalised acceptance of the legitimacy of prisons, it is the mundane routinisation and dull compulsion of the prison that stabilises order in the prison. A similar argument can be made for the penal system in NZ. Prisoners perceive the current order as inevitable and beyond their powers of influence. Under the "unrelenting imposition of authority" (Scraton, Sim, \& Skidmore, 1991, p. 63), prisoners become fatalistic, and the experience of incarceration is simply endured rather than consented to with any reference to legitimacy.

Thus, for Carrabine $(2004,2005)$, prisons are not, and make no attempt to be, legitimate. Nevertheless, introducing a novel mode of punishment, such as private prisons, necessitates active legitimation (Burkhardt, 2014). According to Suchman (1995, p. 587), to establish legitimacy, new institutions need to: make their institution conform to the wishes of the audience; pursue only a section of the audience that already supports them; or manipulate the environment to create a new audience. Although research is scarce, there is evidence that private prison authorities engage in methods of legitimation distinct from public prisons. Despite the unwavering faith in 'heavy' forms of prison management, characterised by greater staff presence, more concrete regulation and staff who quickly utilise coercion, private prisons have developed an ethos typified by 'light' policies, characterised by younger, less experienced staff who have less presence in the prison (Crewe et al., 2014). From a legitimation perspective, this can be viewed as an attempt by prison authorities to foster legitimacy by conforming to the wishes of the prisoners.

Beyond prisoners, advocates of private prison need to secure large-scale consent of the general public (Bottoms \& Tankebe, 2012). Early advocates of privatization have faced 
the challenges outlined in the introduction, including the commonly held belief that punitive confinement is a responsibility exclusively handled by the state, or that private prisons pose a threat to basic human rights (Burkhardt, 2014). Burkhardt (2014) found that advocates of successful private prisons tend to promote instrumental benefits to society, ignoring moral considerations altogether. While this points to specific targeting of audiences, there has not been research investigating the discursive strategies that private prison companies and governments employ or what specifically these instrumental benefits are. The period of media coverage before the Mt Eden scandal provides the opportunity to examine the legitimation strategies employed by Serco, who they pursue, and, importantly, how they attract new supporters.

Literature on institutional and organisational legitimacy indicates that, once legitimacy is established, maintaining it becomes "increasingly perfunctory if not mindless" (Ashforth \& Fried, 1988, p. 183). Of course, incarceration is a unique type of institution; prisons can be dangerous places and prisoners are often the victim of mistreatment and negligence. Prisoners are also subject to the mundane regime of minute regulation. In this regard, Sparks and McNeill (2009) argue that even the most banal prison regimes manage concern related to access to legal representation, adequate health care, accountability mechanisms, nutrition, and work and remuneration among others. Of course, prisons are not always under scrutiny or in the throes of controversy. Having judged an institution legitimate, people tend to relax their vigilance until an event is brought to their attention (Suchman, 1995). Indeed, Burkhardt (2014) argues that the most successful private prison regimes evade issues of legitimacy altogether. They can go years without public attention. Yet, as Sparks and McNeill (2009, p. 5) note, prisons never cease to have "political energy", and penal scandals can disrupt the most stable institutions.

\section{The Power of Scandal}

The threats to the legitimacy of the prison in NZ have consistently risen from scandal (Pratt, 2008a, 2008b). J. B. Thompson (2000) lists five characteristics of a political scandal that illuminate why they so often threaten the legitimacy of the state. First, the event transgresses certain values or moral codes. However, "scandals occupy a sort of middle ground for impropriety” (King, 1986, p. 175). Although small transgressions do not constitute a scandal, larger events such as genocide, would also be considered 
outside the purview of a scandal. The second characteristic, Thompson states, is the involvement of an element of secrecy. Of course, the secret eventually needs to be disclosed to people outside of the parties involved. The third element is the arousal of offence and indignation. Because society is pluralistic, the transgression must offend the moral consciousness of the majority of society. The fourth element involves public disproval; it is not sufficient that the act is considered wrong, some people must publicly express or denounce the actions, usually in the media. The final aspect, for Thompson, is that the scandal must result in damage to the reputation of individuals or parties involved.

In NZ, the subject of penal scandals has been dominated by concerns of insecurity and "failures to protect the community" (Pratt, 2008a; Pratt \& Anderson, 2015, p. 14). The media, as has been noted across different disciplines, focuses on "newsworthy" events. Hence, crime reporting, while sensationalising details, tends to over-emphasise violent and sexual crime (Cheliotis, 2010; Coxhead, 2005; Jewkes, 2013). In this climate, prison scandals tend to galvanise punitive attitudes. In 2006, for example, 17-year old remand prisoner Liam Ashley was beaten to death by another prisoner in the back of a prison van. The media emphasised the failure of the prison to protect the 17 year-old from other 'dangerous' prisoners (Bartlett, 2009). Another prominent scandal involved the case of Graeme Burton, who was serving a life sentence for murder. Released on parole in 2006, Burton went on to murder a man in 2007, before being captured by police. Following sensational reporting during the scandal, blame fell on the parole board for releasing Burton, despite no evidence of wrong-doing (Bartlett, 2009). More recently, Stewart Murray Wilson was granted parole from Whanganui Prison in 2012 after serving an 18.5 year sentence for rape, attempted rape, indecent assault, illtreatment of a child and bestiality (Pratt \& Anderson, 2015). Local outrage at his release, led to the city council petitioning to have him kept in prison. Conditions attached to his parole were far reaching. He was fitted with the first GPS tracking devise in $\mathrm{NZ}$ and he could not leave his house on prison grounds unless accompanied by two guards. He was prohibited from numerous associations and activities, including: having female visitors without prison approval; being in contact with anyone under 16; attending AA meetings; keeping pets; using the internet; attending church; or visiting the library (Pratt \& Anderson, 2015). After Wilson phoned a woman without 
permission, to express gratitude for a Christmas present, he was re-imprisoned (Pratt \& Anderson, 2015).

These scandals, representing a sensationalised, but potent, image of imprisonment, typify the nature and characteristics of the legitimacy problems faced by prison service in NZ and how an environment that facilitates populist posturing can enflame and define prison scandals. One of the most pervasive constructions that is constantly bolstered in penal scandals is the dichotomy of 'us', the law abiding responsible citizen, and 'them', the dangerous undeserving poor (Garland, 2001; Scraton \& McCulloch, 2009). Bauman (1997) argues that all societies have a need to set "the others" apart those individuals who do not fit in. The 'victim' and 'criminal' labels are engendered with connotations that restrict who is recognised as a victim and who garners sympathy (McGarry \& Walklate, 2011; Walklate, 2007). The 'criminal' and its surrogates are described with distaste as a group of individuals distinctly different from "us". As Scraton and Chadwick (1986, pp. 94-95) note:

The continua related to this process - rough/respectable, dangerous/conforming, undeserving/deserving - are employed to construct identities which then justify harsh and differential responses in the enforcement and application of the rule of law.

Strategies for cultivating acknowledgement of rights violations often draw on playing on people's emotions (Cohen, 2013). These strategies may be successful for certain populations, but encounter problems when dealing with prisoners, who are the antithesis of the "ideal victim" (Höijer, 2004, p. 516). The recognition of victimhood depends on the proper performance of a victim identity and requires victims of human rights violations or crime to perform social and political identities that fit into larger moral narratives (Wilke, 2007). Thus, Carrabine (2004, p. 117) speaks of a "hierarchy of victimization". The closer a person is to the archetypal construction of a victim the more likely their rights infringements will be viewed sympathetically (Carrabine, 2004).

The construction of the "ideal victim" (Christie, 1986, p. 17) based on specific lines of class, race and gender provide a cultural image of 'goodness' in which those who are victimised are judged against (Newburn \& Stanko, 1994; Wood, 2005). Vulnerable, 
virtuous and dependent sufferers are afforded sympathy not because the problem of harm itself is unacceptable, but because they personally do not deserve to suffer (Carrabine, 2004). This view simplifies victimization, overlooking the complex relationship between experiencing offending and victimization (Walklate, 2007). As the above scandals indicate, there are many instances where the roles of crime victim and offender coincide. Indeed, offenders are more likely than non-offenders to be victims, and victims are more likely than non-victims to be offenders (Jennings, Piquero, \& Reingle, 2012).

Despite the numerous threats to its legitimacy, Carlen (2002b) has highlighted the uncanny ability of the prison to defend and neutralise critique, and how responses to these threats contribute to the carceral clawback. The narrow construction of the prisoner as dangerous restricts how scandals come to be understood. Inevitably, responses to scandals reflect the way in which they are defined.

\section{Carceral Clawback}

Although it would seem, in the face of scandals, that critical discourses would pose a threat to the legitimacy of prisons, Carlen (2013, p. 220), argues that the prison system neutralises critique by incorporating critical discourses and transforming humanitarian penal reforms in line with correctional interests. This speaks to the way in which some scholars have questioned the liberating effect of human rights, arguing that they have been co-opted as the "ideological gloss of an emerging Empire" (Douzinas, 2007, p. 7).

In order to deflect focus on the flaws of the prison service, the language of critique has been incorporated into official penal discourses (D. G. Scott, 2009). Here it is useful to draw on the concept of discursive legitimacy (Hardy \& Phillips, 1998). Discursive legitimacy refers to the ability of an organisation to represent a discourse. For Vander Laenen and Persac (2014), criminal justice organisations are able to exercise discursive legitimacy as they draw on the strongly held value of the protection of the society against offending. With this discursive legitimacy, the punitive function of the prison is veiled by claims that prisons are for something other than punishment - be that psychological readjustment, training in parenting, drug rehabilitation, or education (Carlen, 2002a). Penal authorities, in adopting some of the language of critique, set the interpretive boundaries of rights language and exclude certain ways of thinking about 
prisoners' rights and their connections with socio-economic contexts as well as the actual, punitive, function of imprisonment (Carlen, 2002a; D. G. Scott, 2009). The suffering of prisoners is obfuscated, as the "truth" of imprisonment is monopolised by penal authorities and the voices of those in prison, experiencing the reality of incarceration, become subjugated knowledges, and denied any authority or value (D. G. Scott, 2009).

At the same time, Carlen (2013) argues that humanitarian penal reforms are undermined by the ascendancy of managerialism and the privileging of security. Positive penal reforms, such as the promotion of rehabilitation are only adopted when they can be channelled to provide greater legitimacy to penal institutions (Mathiesen, 1974). More often, in the wake of public disgrace, politicians fall back to the punitive rhetoric of law and order and introduce symbolic reforms that increase securitisation (Carlen, 2002a) The result, Pratt (2008a) notes, is that episodic scandals are frequently responded to by strengthening repressive and punitive policies. After the death of Liam Ashley, rather than focusing on prison reform or reducing the prison population, the scandal spurred calls for a United States style "Three Strikes law" and waist restraints were added to prison vans (Bartlett, 2009). Similarly, in the case of Graeme Burton, although investigations found no wrongdoing by the parole board, parole eligibility was made more restrictive and recall conditions widened under amendments to the Parole Act 2002 (Pratt, 2006). Finally, in the case of Stewart Murray Wilson, after being reimprisoned for an unauthorised phone call, the government introduced the Public Safety (Public Protection Orders) Act, granting the courts the power to indefinitely detain those who they considered "a high level of imminent risk of serious sexual or violent offending" (Pratt \& Anderson, 2015, p. 2).

Prison legitimation reforms, on the other hand, are responses to long term official criticism (Carlen, 2002b). In an attempt to reassert legitimacy, the prison will frequently pay lip service to change but provide no substantive improvement to life in prison (D. G. Scott, 2009). For instance, the social costs from the prolonged era of mass incarceration, the threat to New Zealand's international reputation, the perceived failure to provide security or decrease recidivism, and the increasing economic costs of the prison system led to Bill English, the Deputy Prime Minister and Finance Minister, to claim that prisons were "a moral and fiscal failure" (Rudman, 2015). In response, the 
government announced the reintroduction of private prisons with the promise of costefficiency and a $20 \%$ reduction of recidivism (Rudman, 2012, March 21). While promoted as a principled reform, the superficiality of these claims is the focus of chapter six.

\section{Conclusion}

Increasingly, the protection of human rights is the benchmark for the legitimate measure of the prison (Sparks \& McNeill, 2009). However, despite the rise of formal legal protections and the permeation of a language of 'rights', prisoners' rights talk in $\mathrm{NZ}$ too often degenerates into mere rhetoric, subsumed under the logic of security and managerialism (Carlen, 2002a). NZ has been notoriously reluctant to incorporate international human rights into domestic law and has continuously struggled with the process of reconciling international legal standards and obligations with domestic cultural values and policy concerns (United Nations Human Rights Council, 2009). The seduction of populist punitive discourse has been so great, that it is assumed all talk about prisons must operate within these self-evident truths and it is not rare that the defence of prisoners' rights is met with disdain (Pratt \& Clark, 2005).

More often than not, the subject of penal scandals involve unease about risk and insecurity, the responses to which bolster the underlying punitive rhetoric of law and order (Pratt, 2008b, 2016; Pratt \& Anderson, 2015). Beyond episodic scandals, the moral indifference to known prisoner suffering is largely the result of excluding prisoners from our moral universe (Cohen, 2013). The responses to human rights violations are in large part mediated by the construction of prisoners as unworthy or less eligible of rights. By placing the prisoner outside the moral community, relegitimation of the prison becomes increasingly easier, perfunctory and superficial.

Nevertheless, the trend of legitimation claims based on indignation with the 'leniency' of the prison system is not inevitable; legitimacy can be staked, and lost, on human rights claims (Sparks \& McNeill, 2009). Toleration of mistreatment is not fixed. As this thesis demonstrates below, the way in which people learn of injustices can play a significant role in expressions of sympathy towards prisoners. With an issue such as prisoner mistreatment, where the public are virtually dependent on the media for information, a number of authors emphasise the importance of photographic or video 
evidence of suffering (Boltanski, 1999; Joye, 2009, 2015). Without visual evidence, public understandings of ill-treatment may be narrowed by the dominant discourses promoted by the government (Bruhn, Nylander, \& Lindberg, 2016; Burton \& Carlen, 1979; D. G. Scott, 2009).Before exploring the nature of the media in NZ and the consequences for how penological issues are discussed, the following chapter outlines the main penological discourses in the public sphere. 


\section{CHAPTER THREE: COMPETING DISCOURSES}

The meaning of prisoners' rights is created in a complex discursive process of competing discourses in judicial decisions, parliamentary reports, the media, and academic research (D. G. Scott, 2009). The legitimacy of each discourse "depends on the formation of opinion and political will in the periphery" (Wessler, 2008, p. 25). In contemporary NZ, neither of the main political parties has been prepared to contest populist punitive notions of the necessity of the prison (Pratt \& Clark, 2005). Opposition has come from long-term campaigning organizations, although, in the populist climate, these discourses struggle for dominance (Grey \& de Roo, 2010).

There have been several different international configurations of penological discourses. For example, H. Mills and Roberts $(2011,2012)$ identified three discourses adopted by penal reform campaigners: crime fighting, humanitarianism and managerialism. Rutherford (1993, p. 26) suggests criminal justice is characterised by three competing penal "credos": humanity, punitiveness and expedient managerialism. In his study of prison officers, D. G. Scott (2009) distinguished six penologies: less eligibility, managerialism, actuarialism, welfare through punishment, liberal humanitarianism, and penal abolitionism. Together, these works foreground the distinctiveness of prisons from other organizations and how the public thinks about them.

The aim of this chapter is to understand the "grids of specification" (Foucault, 1972, p. 42) for talking about prisoners' rights; that is to say what is sayable about prisoners' rights in NZ. First, I briefly outline Michel Foucault's theory of discourse, before detailing the penological discourses of managerialism, safety and security, less eligibility, and humanitarianism. Amalgamating these various frameworks, and drawing from literature on crime and punishment in NZ, these four penologies provide the template for understanding how the NZ media conceptualise the lives of prisoners and their human rights.

\section{Discourse}

Michel Foucault's conceptualisation of the relationship between discourse, knowledge and power are particularly useful for exploring constructions of prisoners' rights. For Foucault (1980a, p. 133), 'truth' is not an objective report of reality, but a "system of 
ordered procedures for the production, regulation, distribution, circulation, and operation of statements". These statements come from bodies of social knowledges, what he calls discourses. The term discourse refers to the way in which language and social practice shapes our understanding and interpretation of reality (Foucault, 1972). Discourse does more than describe a topic, it gives meaning and provides a way of understanding the world (Foucault, 1977). In the case of prisoners' rights, discourse is not only concerned with simply defining rights, it involves the way we think about prisoners', the way we talk about crime, and the way it influences our conduct.

Rather than locating the exact origin of a discourse, Foucault (1991, p. 59) sought to interrogate the rules that allowed certain ways of understanding to be preferred over others. Although there are multiple discourses of prisoners' rights, some discourses are more likely to be accepted as common sense. Common sense discourses, those deemed 'natural', are not defended by the validity of their ontological or epistemological assumptions. Rather, rejecting the notion that knowledge flourishes in the absence of power, Foucault (1977) argued that common sense discourses, are intrinsically connected to power, as he summarised:

We should admit ... that power produces knowledge ... that power and knowledge directly imply one another; that there is no power relation without the correlative constitution of a field of knowledge, nor any knowledge that does not presuppose and constitute at the same time power relations (Foucault, 1977, p. 27).

Thus, 'truth' as commonly accepted, is the result of a discourse reinforced by institutions of power. Each society has a "regime of truth" made up of the political, economic and institutional structures that provide the 'truth' (Foucault, 1980b, p. 133). Equally important to the power/knowledge nexus of discourse, is the silencing of competing discourses (Burton \& Carlen, 1979). In the case of 'penal truths', D. G. Scott (2009) has noted that 'truth' is most often the product of sanitised official discourses, with "subjugated knowledges" of prisoners dismissed or neglected as irrelevant. Even those accounts that include unofficial discourse favour accounts from prison officers, who work within the boundaries predetermined by the legitimated knowledge base of the prison system (Sim, 2008). 


\section{Managerialism}

Given the ongoing criticism faced by the prison system over the last thirty years, the institutional discourse of punishment has increasingly focused on the issue of how to punish, rather than why to punish (Bottoms, 1995). Rather than wider social purposes, the management of the prison has become a central objective of the prison in itself (Feeley \& Simon, 1992). The Department of Corrections is inherently distinct from other service providers, involving the infliction of pain, yet this fact is hidden under managerial rhetoric (D. G. Scott, 2009). Borrowing from the private sector, developments are articulated through a technical discourse that concerns formal criteria that can be measured and compared to competitors (Osbome \& Gaebler, 1993).

Managerialism prioritises the management of current resources and budget allocations to meet performance targets, rather than wider social problems (Bottoms, 1995). The business rationalisation also limits the scope of the prison by prioritising the central activities to be evaluated and compared. 'Inessential,' non-core activities are abandoned in the name of efficiency and cost-saving, and unless an activity is explicitly defined as a core business activity and measured through performance indicators it remains irrelevant (D. G. Scott, 2009). Underscoring the managerialist logic of the NZ prison system, the 'success' of NZ prisons are primarily illustrated through the publication of comparative performance tables of explicit Key Performance Target Indicators (Department of Corrections, 2016a).

Closely aligning with neoliberal logic of giving the public greater choice and individual freedoms, managerial reforms are the catalyst to shrinking the public sector (Mayr, 2008). The promise of "autonomy, entrepreneurship and innovation" (D. G. Scott, 2009, p. 50), while guaranteeing quality and cost effectiveness embraces already established ideas of the consumer, making it a particularly attractive discourse (Peters, 1992). The introduction of private prisons is the quintessential initiative driven by a managerialist ethos cloaked in rhetoric of rehabilitation and humanitarian reform. Dolovich (2009, p. 129) highlights that the debate over prison privatisation primarily plays out within the "comparative efficiency" framework. The insistence on comparison, and only comparison, promotes the disregard of important features of imprisonment. Dolovich (2009) uses the example of levels of violence between public and private prisons. The obscene levels of violence in both public and private prisons 
are largely ignored in the discussion over prison privatisation because they reveal nothing over which is the better choice. Instead of prompting a system wide examination of prisoner mistreatment, the comparative efficiency framework restricts debate to the differences, which often deteriorates to considerations of cost minimization (Dolovich, 2009).

The logic of managerialism has also permeated the relationship between the prisoners' rights lobby and the government. Grey and Sedgwick (2013) argue that the replacement of the social contract with the competitive contract as the focal point for relations between the voluntary sector and the state has contributed to an environment which generates fear and redirects attention to surviving at the expense of public debate. Funding is allocated according to ideas of contestability and efficiency. In addition, the state's desire to deal with preferred providers exacerbates the monopolistic behaviour of the contract environment. Consequently, A. Mills (2015, p. 123) described NGO's as "little fingers of the state", whose independence and ability to respond to the needs of prisoners comes under threat.

What does this mean for prisoners' rights? Clarke and Newman (1997) argue that managerialism, at best, can only provide the illusion of rights. Accountability and transparency become superficial rituals, providing an account of the prison service but not holding anyone to account (D. G. Scott, 2009). The logic underscoring this discourse that compartmentalises activities of the prison, leads to the compartmentalisation of the needs of the prisoner. If certain rights are not explicitly included in the performance measures of the prison system, any claims to them will be met with indifference.

\section{Less Eligibility}

One of the most enduring notions related to the treatment of prisoners, what is known as the principle of less eligibility, is that they should not be treated as well as those outside of prison (De Giorgi, 2006). A remnant of the poor laws in the United Kingdom, the principle of less eligibility assumes that in order for the penal system to function as a deterrent it must impose on those it punishes a standard of living that is worse than those available to the most marginalised outside the penal system (Sparks, 1996). Resentment towards 'soft' penal measures is cultivated with continued comparison 
between 'extravagant' prison conditions and the hardships of worthy law-abiding poor citizens (D. G. Scott, 2009).

Prisons are inevitably measured by appropriate austerity; that is concern that they might "not be dreaded enough" (Forsythe, 1987, p. 145). Under the logic of less eligibility, debates about prisoners' rights often descend into a zero-sum game where victims' rights can be won only at the expense of the rights of prisoners (Drake \& Henley, 2014). Positioning prisoners versus victims is a powerful ideological tool, which has the result of delineating who is deserving of legal protections and who is not (D. G. Scott, 2009).

Parliamentary debate clearly reflects the dichotomy between victims and offenders. National MP Georgina Te Heuheu attacked the proposal of the Prisoners' and Victims' Claims Bill 2004, on the grounds that prisoners were undeserving of any compensation:

Members will recall that this legislation came about because of some huge payouts made to some of our worst criminals. The public rightly got up in arms and said: "What about the victims?", and now we have a bill before us that deals with compensation paid to some of our worst criminals for supposed hurts they suffered while they were under the care of the Department of Corrections... It is interesting that there are more provisions for - and, I would say, barriers to victims getting hold of any compensation than there are for the crims... That is what this Government thinks of victims. It absolutely does not care about victims. Shame on it! (Grey \& de Roo, 2010, p. 42)

And while victims have been successful at winning the attention of politicians, this strength has not been converted into personal benefits (Simon, 2007). Instead, in the logic of modern penology, victims benefit only by the increase of overall security through the punishment of the person responsible (Zimring, 2004).

\section{Safety and Security}

Prison authorities have increasingly become concerned with "techniques for identifying, classifying and managing groups assorted by levels of dangerousness" (Feeley \& Simon, 1994, p. 173; Garland, 2001). D. G. Scott (2009) argues that the current punitive climate is the result of a gradual trajectory from risk management to risk control. Where previously these controls were seen as undermining the core values 
of Western criminal justice, and reserved only for extreme cases, Pratt (2016, p. 2) argues that the range and extent of these measures of control and management has increased substantially, representing the emergence of a "security state". Not only concerned with managing the risk of future crimes, criminalisation has become linked to eliminating risk entirely by "categorical suspicion" (Hudson, 2003, p. 61) of certain offenders. Thus, D. G. Scott (2009) argues, rather than a temporary suspension of rights, incarceration now represents the permanent exclusion of offenders.

Risk-based policy has since become far more prevalent throughout most Anglophone countries (Hudson, 2001; Pratt, 2016; Whitty, 2010). Occluding the punitive function of the prison, the public is promised insurance against the risk of crime through the logic of security, public protection and crime prevention (Pratt, 2016). In both name and rhetoric, the discourse of public protection was clear when NZ introduced the Public Safety Bill, under the premise that, "people must ask themselves whether they would place someone who has a very high risk of imminent and serious sexual or violent offending in any community in NZ, let alone their own" (NZH, 3023, p. 13441, as cited in Pratt \& Anderson, 2015, p. 4). A crime is no longer punished on the basis of a person's responsibility for the crime committed, but through the clumsy 'scientific' analysis of their background and personal characteristics and the correlation with such factors in the population as a whole (Hudson, 2003).

While the prison remains the dominant tool against crime risk, risk control has moved beyond the walls of the prison, controlling a much larger population, some of whom may not have committed any crime at all, but whose status (e.g. beggar) is an indicator that they are potentially dangerous (Pratt, 2016). In practical terms, the discourse of risk and security is best exemplified in the unprecedented increase in the use of 'preventive detention', handed down to individuals convicted of violent or sexual crimes who are judged likely to reoffend if released. Such individuals will only receive parole if they can demonstrate they no longer pose a threat to the community. From the 1980s, previous barriers restricting the use of preventive detention were steadily dismantled, and compared to the 11 preventive detention prisoners in 1981, there were 260 in 2014 (Department of Corrections, 2014). The distinctive function of the prison today is "a social waste management facility' (Simon, 2007, p. 142) - where adults 
distinctive only for their dangerousness to society are concentrated for purposes of protecting the wider community.

\section{Liberal Humanitarianism}

Captured in the Paterson dictum, that "individuals are to be sent to prison as punishment not for punishment" (G. Richardson, 1984, p. 4), humanitarian discourses share a commitment to decent prison conditions, acknowledgement of human rights and consider prison as only a suspension of offenders' liberties (D. G. Scott, 2009). Although the 'humanitarian' label constitutes a broad field of positions, broadly, those who adopt a liberal humanitarian ethos argue for as much restriction on the use of prison as possible, limited only for the most serious crimes (D. G. Scott, 2009).

In many ways, humanitarian approaches require legal engagement. For example, G. Richardson (1985a, 1985b) provides an argument for expanding the legal discourse on prisoners' rights. He argues that while it is legitimate for the state to suspend certain legal rights, prisoners not only retain all remaining general rights of citizenship, but that the prisoners' involuntary dependence on the state entitles them to additional "special rights". These special positive rights guarantee adequate food, clothes, living conditions, medical and recreational facilities, and provide optional therapeutic treatment, employment, educations and vocational training. To ensure that prisoners have an avenue to hold prison authorities accountable, these positive rights would need to be legally enforceable (G. Richardson, 1984).

The most significant legal recognition of human rights domestically was the enactment of the New Zealand Bill of Rights Act 1990 (NZBORA). Although the NZBORA has been charged as nugatory (Geddis, 2009; McLean, 2013), both judicial intervention in NZ prison life and the recognition of prisoners' rights by the legislator has made significant progress since human rights became a salient political issue (Stanley, 2011). Palmer (2013) concludes that the NZBORA has had an important effect in securing adherence to the principles that it contains and ensuring that parliament, the courts and public authorities respect the human rights it contains better than before it was enacted. The NZBORA has been followed by further human rights legislation including the Human Rights Act (1993), which sets out the role of the Human Rights Commission. For the prison in particular, the Corrections Act (2004) and the Corrections Regulations 
(2005) establish the legal boundaries within which the prison service operates. To protect these rights and enforce legal boundaries, a Corrections Inspectorate was established under the Corrections Act and external oversight of prisoners is provided by the Ombudsmen's Office.

New Zealanders have a strong sense that human rights have been especially important in the history of the country, celebrating women's suffrage, opposition to apartheid and nuclear weapons, as well as the improvement of indigenous rights. On the international stage, NZ was at the forefront of developing the United Nations international covenants on human rights, and successive NZ governments have given a commitment to creating an environment in which "human rights considerations are at the heart of public and international policy development" (Ministry of Justice, 2000, p. 16). In NZ, humanitarian concerns for prisoners have been primarily promoted by pressure groups such as the 'Howard League for Penal Reform', 'PARS' (formerly 'Prisoners Aid and Rehabilitation Society'), or 'Just Speak'. These NGO's call for greater accountability, reform of the criminal justice system, and provide rehabilitation and education programmes (Gilbert \& Elley, 2013; JustSpeak, 2014; PARS, 2014; Taylor, 2011).

Captured under the banner of humanitarian discourse, and similar to Scott's (2009, p. 51) notion of "welfare through punishment", rehabilitation is consistently touted as one of the primary ends of imprisonment (e.g., Department of Corrections, 2016b). While the trust in rehabilitation weakened significantly with the decline of the welfare state, rehabilitation reflects the historical mission to "save" the underclass from a life of crime (Faulkner, 2006, p. 103). Originating from a political vision prioritising self-discipline and individual responsibility, the prison is presented as an opportunity to reduce reoffending (D. G. Scott, 2009). Under the discourse of rehabilitation, prisoners should be responsibilised, trained and disciplined so that they can be integrated back in to the community. However, D. G. Scott (2007) argues, this takes on new significance in the context of increasing securitization and the declining commitment to social insurance. The individualisation of responsibility for rehabilitation and reintegration fails to account for the extreme constraints of the penal environment and obfuscates the social context that contribute to criminal offending (D. G. Scott, 2009). 


\section{Conclusion}

This chapter has outlined the rules and structures of the four main penologies on prisoner human rights in NZ. Given various levels of exposure, these frameworks shape discussion about prisoners' rights. The peculiar politics of modern punishment, characterized by a hybridisation of a pre-occupation with the administration of punishment and the populist tendencies of politicians and moral entrepreneurs has engendered a social, economic and political context that fuels a penology that largely denies prisoners' rights (Sparks, 2000b). Although these discourses appear disparate, the pattern of emergence at any one time is "dynamic and recursive" (Sparks, 2000b, p. 133). Due to the enduring belief that human rights are conditional, available only to the respectable and worthy, humanitarian discourses continue to be undermined by competing, and stronger, discourses of managerialism, less eligibility and security.

The major focus of this thesis is to ascertain how these discourses act to legitimise or delegitimise private prisons. For Foucault (1972, p. 41) a discourse of prisoners' rights will emerge across a number of "institutional sites". While Foucault did not specifically deal with the mass print media, it is certainly one of the most important as journalists direct public attention to certain issues and set the 'agenda' of public discourse (McCombs, 2004). Indeed, the public's knowledge about the prison and those who inhabit it is often based entirely from these accounts (Wilson \& O'Sullivan, 2004).

There is a body of research conducted over decades that has found that the mass media has consistently expressed punitive attitudes in relation to crime and punishment (Barak, 1994, 1995; Jewkes, 2015; Mason, 2009). However, hegemonic discourses are not fixed. The media holds the same potential for emancipation as it does for repression (Fuchs, 2009a). Foucault (1972, p. 200) notes that within any discursive formation, there will a diversity of positions that can be occupied: "[It is] possible for men [sic], within the same discursive practice, to speak of different objects, to have contrary opinions and to make contradictory choices". It is anticipated that the media construction of prisoners' rights will uncover competing lenses as well as frameworks that overlap and complement each other. The following chapter examines literature on the role of the media and the political economy of the media in NZ, investigating what contributes to the creation and limitation of news content. 


\section{CHAPTER FOUR: MEDIA AND THE PRODUCTION OF 'TRUTH'}

So far this project has investigated issues of penal legitimacy, and the construction of discourses around prisoners' rights. Before examining how prisoners' rights and the legitimacy of private prisons have been presented by the news media, it is important to consider the role of the news media within the political economic system of NZ. The mass media, while not the only aspect of constructing and propagating cultural ideas and images, is certainly one of the most important (Barak, 1995; Ericson, Baranek, \& Chan, 1987). Although the link between media coverage and public perception is not completely understood, the connection is more than tenuous. Research has consistently shown that the public overwhelmingly relies on the media for information about nonlocal crime and punishment (Altheide, 2006; Bradley et al., 2011).

It is often touted that the media acts as the "fourth estate", holding the government to account. Indeed, Apodaca (2007) found that higher levels of communication access, to any mode of media, is associated with reduced human rights violations. Journalism has a number of normative "news-values" that describe what the profession itself believes the ideal role of journalism and the media should have. The "occupational ideology" (Davis, 2007, p. 36) of professional journalism, or their "journalistic role conception" (Hellmueller \& Mellado, 2015, p. 1), maintains that if the professional value of balance is upheld then the various points of views will be represented in the media (O'Neill, 1990). The journalist ideology described by Deuze (2005, p. 447), including public service, objectivity, autonomy, immediacy and ethics, is an ideal model for an emancipatory role of news media. For those who are so often bereft of human rights, the media, as a purveyor of public information and education, may be their only tool for protection. Unfortunately, as Hellmueller and Mellado (2015) points out, there is a stark tension between a journalist's role conception and their role performance. Despite efforts to remain neutral, unbiased and honest, the theory of a detached, objective provider of information does not reflect the various interests and influences on the framing of the news (Morrison, 2002).

While recognising the importance of the media for emancipation, the majority of news organisations are for-profit institutions, primarily concerned with selling a product. 
Thus specific questions of "which human rights, whose human rights, from whose perspective and on the basis of what criteria" (ICHRP, 2002, p. 17) instruct news coverage. Thus, a holistic view of the media is central to any study of how penal issues are reported in the mass media. In reality, the nature of the media system is messy. The media can hold the state accountable on one day and favour state interests on the next (Fuchs, 2011). Fuchs (2009a) argues that the mass media is antagonistic, posing the same potential for emancipation and repression, reflecting the tensions within capitalism. Given the distribution of capital and model of political power in NZ, the emancipatory potential of the media is largely subsumed under the existing dominant structures. While, on media freedom, NZ rates as one of the most free in the world, ultimately, news events are framed in order to satisfy corporate requirements (Murdock \& Golding, 1973). This chapter outlines the corporate influences on news outlets in more detail, drawing on literature from the political economy of the media (Fuchs, 2009a; Mosco, 1996) and mediated suffering (Boltanski, 1999; Chouliaraki, 2006; Kitch \& Hume, 2008).

\section{Commodification of News}

The mass media are first and foremost commercial organisations that produce commodities (Murdock \& Golding, 1973). As a commodity, news content is transformed from information into uniform and simple marketable products, inevitably distorting the content (Horkheimer \& Adorno, 2006). Media representations consist of the perspective that captures the attention of the public to entice them into consumption. There is little argument that crime, especially violent and interpersonal crime, is a staple of news (Chibnall, 1977; Chiricos, Eschholz, \& Gertz, 1997; Ericson et al., 1987; F. Harris, 1932; Marsh, 1991). Indeed, in one of the first studies of crime in the media, Ericson et al. (1987, p. 4) found that "social deviance" was "the defining characteristic of what journalists regard as newsworthy”. In a NZ content analysis of three online news websites, Burgess (2014) found that, across all three sites, crime news was: the most frequent topic of lead stories; the most popular topic with readers; and, had the most coverage compared with 22 other topics. Given this exaggerated coverage, it is not surprising that a 2013 survey commissioned by the Ministry of Justice found that, despite reported crime being at the lowest point in 33 years, more than half the population thought crime was on the rise (Colmar Brunton, 2013). 
Due to the deregulation of the NZ media and tendency towards privatisation, ownership of the media is highly concentrated among a handful of private funds and investment banks (Myllylahti, 2016). The market model means there is little regulatory encouragement of diversity. As such, in May 2016, with a near duopoly on newspapers and magazines ${ }^{3}$, NZME and Fairfax NZ announced merger talks, pending Commerce Commission approval. While numerous blogs, podcasts, radio shows, and YouTube series offer alternative perspectives, the traditional media of television, radio and newspapers not only continue to dominate the overall media sphere, they also have significant resources to invest in new communication networks. Thus, not only are the broadsheet newspapers of Fairfax the most widely read in NZ, but Stuff, the aggregate website of these newspapers is the most visited news website in NZ and the seventh most visited of any website (Alexa, 2016). It would be naïve to assume that the power of the mass media can be undone through the transformative power of blogs, social networking and other user-generated content (Chakravartty \& Schiller, 2010).

While a corporation or shareholder may not necessarily interfere directly with news content, they can still influence news production. Ownership can indirectly influence what journalists choose to cover. Journalists will pre-emptively self-censor what they write in order to protect their job and future career job prospects (McChesney, 2004). As Curran (2002, p. 149) noted:

The media are increasingly big businesses. They have a material interest in promoting market friendly policies. Their principal shareholders and top executives are wealthy people, with a stake in the status quo. They influence the ethos, direction and goals of these organisations through the setting of policy, the hiring and firing of key staff, and the allocation of rewards.

One NZ state broadcaster has provided a source of integrity against the nature of commodified news - Radio New Zealand (RNZ) is the only public service broadcaster in the country. There is no longer a state broadcasting authority in television performing

\footnotetext{
${ }^{3}$ In 2008, NZME (a trans-Tasman media corporation with Irish media corporation INM and Irish telecom billionaire Denis O'Brien as its substantial shareholder) owned $42.4 \%$ of the daily newspaper circulation, $27.7 \%$ of which is the New Zealand Herald, the largest daily newspaper in the country in 2008 (Rosenberg, 2008). Fairfax Media, an Australian headquartered media corporation with Australian mining billionaire Gina Rinehart as its largest shareholder, owned almost half (48.6\%) of all newspapers in New Zealand in the same year.
} 
the role as purveyor of public information or education through which the veracity and authority of other commercial outlets can be judged. Although TVNZ is owned by the state, it has no public service obligation and 95 per cent of its operations are funded by advertising. Similarly, while Māori Television is funded by the government and $\mathrm{Te}$ Mangai Paho, it has a specific interest in revitalising Māori language, with an objective to be "an independent Māori television service that is relevant, effective and widely accessible" (Māori TV, 2014, p. 18).

Smythe (1977) identified the role of advertising in the commodification process and argued, somewhat metaphorically, that the audience is the primary commodity of the media. As well as creating ideologically saturated products, the media industry increases profit through the "advertising-circulation spiral" (Fuchs, 2009b, p. 21). The 'true' commodity buyer of the mass media is not the consumer of media content, but the advertiser who is sold the audience (Murdock \& Golding, 1973). Those corporations that attain revenue through advertising are likely to increase circulation, which will increase their audience, and thus be more attractive to advertisers, ad nauseam. Broadcasters and publishers are increasingly able to identify more specific demographics about audiences. This has resulted in what Castells (2013, p. 60) calls "narrowcasting", in which news outlets have fragmented into hundreds of minor stations targeted at specific audiences. Similarly, websites like Facebook and YouTube record the browsing habits of consumers, which can then be used to target specific audiences (Mosco, 1996). For example, Acxiom, a data broker company has a database that contains the information of 500 million active consumers, with an average of 1,500 data points for each user (Singer). With pressure to maximise profits, media institutions, with this information, tend towards ideological homogenization and "audience pleasing dramatization" (Benson, 2004, p. 282). On this view, we might expect to find radically different views depending on the target audience of news outlets.

\section{The Role of 'Experts'}

The key to understanding how journalists locate the prisoner within the social and moral universe relates to who they get their information from. The journalistic field is defined by its relative position to the "world at large" and its dialectical relationship with other fields (Hirst, 2012). A discourse on private prisons and prisoners' rights requires "authorities of delimitation" (Foucault, 1972, p. 41), such as politicians, senior civil 
servants, or in some cases, the corporate professionals in charge of private prisons. Journalists, as "quotidian intellectuals" (Hirst, 2012, p. 48), rely heavily on expert sources to provide meaning to events, what it is to be a prisoner, and the appropriate scope of human rights application.

Although journalists have relative autonomy, that is to say they have their "own law of functioning, without being completely independent of external laws" (Bourdieu, 2005, p. 33), they direct the public discourse about punishment and human rights within a subordinate relationship to social actors from other professional fields (Bourdieu, 2005). A key element of source power is the ability for privileged sources to frame a debate or discussion (Herman \& Chomsky, 1994). Journalists will typically seek out sources that are perceived as competent and credible, in order to maintain the image of their own credibility. Hall et al. (1978, p. 71) use the term "primary definers" to describe these privileged sources, often approached first to understand a news event or issue. Additionally, the intense expansion of public relations in the political sphere has seen the consolidation of media access to political and corporate elites (Davis, 2000; Moloney, Jackson, \& McQueen, 2013). According to research from Lewis et al. (2008) business and PR stories were three times more likely to make it into the news compared to NGOs, charities, and other civic groups. Hallin's (1989) three-sphere model posits that it is primarily internal variation in elite consensus and disagreement between elites which defines the range of viewpoints expressed in the media. Consequently, scandals or controversial issues are largely restricted into safe areas of "legitimate controversy" (Hallin, 1984, p. 21).

In crime news, the police have been consistently found to be the primary source for journalists (Ericson et al., 1987; Jewkes, 2015; Sherizen, 1978; Surette, 2015). Police accommodate the press and are valued for their inside information. Chibnall (1977, p. 155) described the relationship between the news media and police as asymmetrical, "because the journalist is always in an inferior negotiating position - the reporter who cannot get information is out of a job". For prison events, Surette (2015) found that correctional personnel are the least likely criminal justice personnel to be quoted in news stories, reflected in the limited coverage about the internal life of prison compared to other crime stories. 
Despite the reluctance of corrections workers to provide information to the media, "voices from below", in this case prisoners, receive far less attention or visibility in the media (D. Brown, 2008). The accounts of prisoners are often discounted, not due to an impartial judgement of the content of their claims, but by a blanket disregard based on the moral label of 'prisoner' or 'offender' and the associated connotations (D. Brown, 2008; Pratt, 2002). Previous research in NZ has found that law and order lobby groups, such as the Sensible Sentencing Trust, have been granted a privileged position by the media (Bartlett, 2009). An examination of news sources for prison privatisation is important for further exploring who has the power to define public knowledge of the prison.

It is important to offer a qualifier on the power of news sources. The relationship between journalists and sources, however consolidated, is symbiotic (Comrie, 2012; Davis, 2009). On the one hand, journalists need quick access to information from insider sources to understand the complex machinations behind political actions. On the other hand, politicians also need access to the mass media to maintain their profile and support. Davis (2007) contends that media research must frame the relationship between the media and sources beyond a stimulus-response or simple agenda-setting model.

\section{Prisons and the Politics of Pity}

It is through the mass media that we learn about the prison (M. Brown, 2009). Although obvious, this points to the fact that not all events in the prison receive the same amount of attention and that different types of events are framed in different ways. While all victims deserve recognition, this is hard to reconcile with the uncomfortable fact that some categories of victims generate greater levels of compassion in media audiences (Höijer, 2004). Those who are themselves suspected of serious wrongdoings, and fall outside the category of the ideal victim, may therefore find it hard to be positioned in media discourses as worthy of rights protection (Gies, 2015).

It is useful here to draw on literature on "distant suffering" and the interventions required to tackle public indifference to the suffering of those geographically removed from audiences (Boltanski, 1999). The literature detailing the "politics of pity" (Boltanski, 1999) has traditionally focused on the Global North media's coverage of 
tragedies in the Global South, however it provides a valuable entry point for considering the mediation of prisoners' suffering, given that this group is distanced from media audiences. Indeed, the exclusive notion of citizenship, outlined in the previous chapter, has fostered this cultural distance (Bell \& Scott, 2016). For example, in an analyses of newspaper coverage of human rights in the UK and US, Mooney (2012, p. 175) found that discourses associated with criminals revealed:

...a particular construction of human rights as transactional and only available to the worthy. That is, some individuals are said to be undeserving of human rights, specifically of legal human rights, because they have broken the law in particularly egregious ways. The logic underlying this position is that human rights are earned, that they are 'payback' for good citizens and hence can be taken away from bad citizens. (2012, p. 175)

The concentration of violent and sexual crime and the tendency to exclude broader structural processes constructs the prison and prisoners within a narrow discourse of fear and dangerousness (Mason, 2006). The rhetoric of evil, often conjured to describe crime (Silverstone, 2007), has the purpose of separating the rights-worthy from the unworthy. To be labelled as evil is to be expelled from the realm of rights protection. Although this pattern of crime news is not some conspiratorial organized attempt to create fear, distorting these issues casts doubt on the legitimacy of prisoners' rights. By placing the prisoner outside the moral community, mistreatment and suffering becomes increasingly easy to minimise (D. G. Scott, 2009).

\section{Conclusion}

The world is increasingly shaped by and centred on the 24-hour-cycle of information and entertainment that characterises the modern media landscape. In many ways the media define political life, sets the boundaries of public discussion, mobilizes or subjugates social movements, and constructs the meaning of punishment and crime control.

Regardless of the way in which media discourse is received by audiences, the media is undeniably one of the most powerful cultural institutions (Murdock \& Golding, 1973). The regulatory limits to media expansion have been removed in NZ, with market liberalization in the late 1980s and 1990s producing one of the world's most 
deregulated media sectors (Kemp, 2000). Hence, media capital is highly concentrated among a handful of private funds and investment banks and their need for profit profoundly influences news content and the overall nature of media products. For Mosco (1996, p. 55), the concentration of "cultural power," seen in the mass media leads to the perpetuation and defence of ideological hegemony by those who own and control the means of communication, and journalists and editors struggle to take a stand that subverts corporate or political interest.

Additionally, the discourse of prison privatisation in the media cannot be separated from the relationships of power and political agenda. While neither prisoners' accounts nor official discourses offer 'the account' of the experience of prison, they are both partial accounts that can elucidate aspects the other overlooks. However, due to the dominant images of dangerous and immoral criminal offenders, and associated processes of Othering, journalists rely heavily on official sources and are thus likely to restrict discussion to the boundaries provided by corporate and political sources. Without prisoners' accounts, we are left with what D. Brown (2008) calls "the sanitised prison of official discourse".

This may help to explain why Cheliotis (2010) concluded that the mediated visibility of the prison has not invited much sympathy for prisoners. As Jewkes (2013, p. 151) outlined, "For so long have the press and television media ... constructed [them] as stigmatised "others", that the possibilities for empathy have closed down to all but those who have experienced incarceration, or have some other relevant experience on which to draw".

It is important to point out that speaking of "the media", referring to a coherent and homogenous whole, is a gross oversimplification of the various discourses not only between news outlets but also within them. Despite horizontal integration of various modes of news media, there will be relevant differences within mainstream media. Although media analysis involves searching for patterns of similarity, there are some established points of departure that should be explicitly considered, such as the differences between corporatized media and state-funded media companies. Thus, Radio NZ, the only state-funded media with an explicit agenda of education, will be considered beside two commoditised media outlets. The following chapter outlines the method and methodology most appropriate for investigating the discourses around 
prison privatisation and prisoners' rights, namely utilising critical discourse analysis (Fairclough, 1992, 2013; Fairclough \& Wodak, 1997). 


\section{CHAPTER FIVE: METHODOLOGY AND METHODS}

With a focus on the Mt Eden Prison scandal, this thesis analyses mass media representations over a seven-year period (2009-2016). The research design relies on the idea that mass media representations simultaneously reflect and influence society's ideas about punishment and human rights. My method considers 648 news articles retrieved from one print newspaper (New Zealand Herald) and two online news outlets (Radio NZ and Stuff). In order to analyse legitimation strategies and techniques, it was important to investigate the qualitative nature of media discourse. While methods of quantitative content analysis provide a raw count of the sources and primary frames, qualitative critical discourse analysis enabled me to identify the strategies of legitimation and the discursive practices behind them. After briefly outlining the sampling strategy, this chapter outlines these methodologies under the overarching concepts of social constructionism and discourse.

\section{Sampling Strategy}

As it is not possible to survey all newspaper coverage of private prisons, it is necessary to conduct a sample. Articles were selected from March 2009, when the legislation allowing private prisons was tabled in parliament, until March 2016, when this research began. This time period, while being recent also provided two distinct periods to compare the news coverage of prisoner rights - in the absence and presence of a human rights scandal. The key research word "prison" in combination with either "privatisation" (or the alternative spelling), "private" or "Serco" was used to find articles from the NZ Herald, Stuff and Radio NZ from the Newztext database. After irrelevant articles were manually removed, there were 648 articles. Radio NZ gave the most attention to prison privatisation, with 326 articles followed by NZ Herald and Stuff, with 214 and 110 articles respectively. As can be seen by Figure 1, the coverage across all outlets followed a similar trend with moderate coverage from 2009 to 2014 and considerable increase after the scandal in Mt Eden Prison in 2015. 


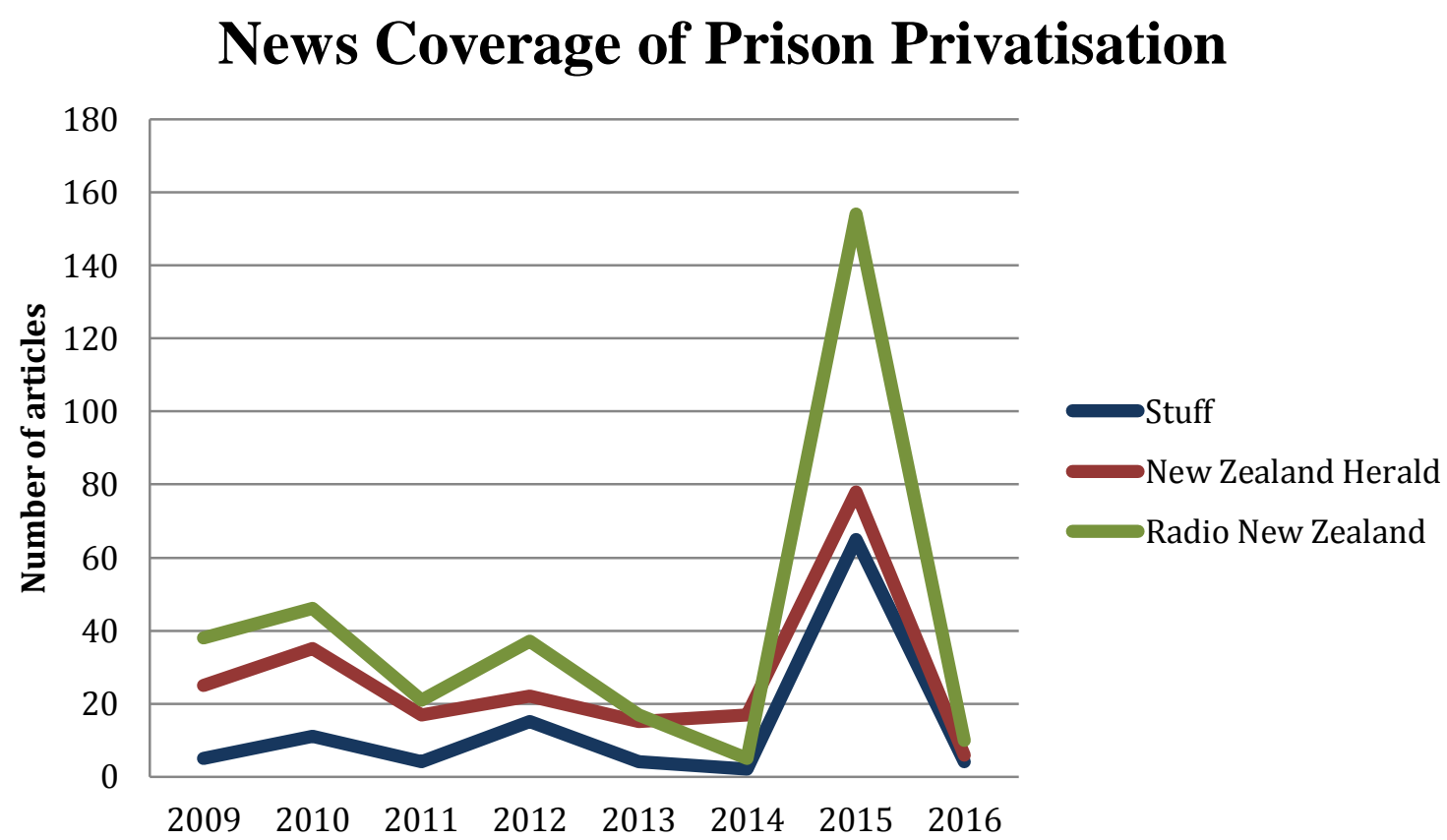

Figure 1. Total Articles on prison privatisation

These three outlets allowed for a broad impression of the NZ mass media. The NZ Herald is owned by APN, a trans-Tasman media corporation that owns $42.4 \%$ of the daily newspaper circulation, $27.7 \%$ of which is the NZ Herald, the most widely read newspaper in the country. Similarly, Stuff is the most read online news source in NZ and is owned by Fairfax Media, an Australian headquartered media corporation that owns almost half (48.6\%) of all newspapers in NZ. On the other hand, Radio NZ is the only public service broadcaster in the country that has an explicit aim to educate and inform.

\section{Critical Discourse Analysis}

Critical discourse analysis (CDA) provides a useful framework for examining the legitimation of private prisons. CDA is a methodology that examines the role of language in the construction of power relationships (Fairclough, 2013). This is particularly important in analysis of the news media as 'the selection of information' is a 'core activity of journalism' and '[t] he apparently passive act of selection is...an act of active construction, a form of giving meaning, a form of guided interpretation' (Poerksen, 2008, p. 297). This offers a methodology to study the "politics of meaning" (Ferrell, 2013, p. 257) in how issues, social groups or individuals are represented in the media. 
Media text is understood as a reconstruction of reality determined by a combination of factors conditioning the journalist's perception of the world, including the news sources, journalistic routines and practices, organisational pressures, broader political and economic processes and ideological and hegemonic factors (Gamson, Croteau, Hoynes, \& Sasson, 1992). The theory of social constructionism captures a broad range of methodologies, however, there are some guiding elements to consider: (1) Develop a critical approach to taken-for-granted knowledge; (2) Embrace historical and cultural specificity; (3) Understand that knowledge is sustained by social processes; and (4) Reflect the links between knowledge and social action (Burr, 2015, p. 2-5). Through this perspective, various qualitative and quantitative methods can be employed to deconstruct media texts and uncover the political, institutional, economic and ideological influences.

From this perspective, it is the discourses that determine the legitimacy of private prisons. Hurrelmann et al. (2009) propose a discourse analysis approach to legitimacy research, which focuses on ways in which legitimacy claims are developed and affirmed in the public sphere. The core idea of this approach is that beliefs and claims are to a large extent the product of public discourse within a given polity. A focus on legitimation discourses reveals what may be said in debates on private prisons, what has a chance of being taken seriously, which positions and justifications are hegemonic and ultimately, which rules there are for the formulation of acceptable legitimacy evaluations.

Critical discourse analysis (CDA) evolved from the critical linguistics tradition (e.g. Fowler, Hodge, Kress, \& Trew, 1979), and proposes that language is a form of social practice (Machin \& Mayr, 2012) that is linked with power and ideology (Fairclough, 1992). As such, a natural development was a method and theory that captured the interrelationship and describe the practices and conventions behind texts that reveal political and ideological investment (Fairclough \& Wodak, 1997). There are a number of different approaches to CDA, all which take existing social problems as a point of departure. This focus on the role of discourse in the production, reproduction and challenge of dominant relationships (Van Dijk, 2015), is particularly appropriate for Fuchs (2011) integrative typology of the media's role in domination. 
Although there is not one single homogeneous version of CDA, it has been primarily associated with the ideas of Norman Fairclough, Ruth Wodak and Teun van Dijk. Each build on the work of the Frankfurt school, adopting a cultural-Marxist stance grounded in an understanding of power, ideology and discourse as a social practice transmitted and constituted in part by language: language both shapes and is shaped by society (Machin \& Mayr, 2012). The 'critical' aspect of CDA refers to a departure from description to consider why and how these features are produced and what ideological goals they serve (Fairclough, 2013). Machin and Mayr (2012, p. 5) refer to this process of revealing absences and taken-for-granted assumptions in text as "denaturalising" the language.

Three main models of CDA have been developed: (i) the socio-cognitive model emphasises the cognitive aspect of discourse (Van Dijk, 1998); (ii) the discoursehistorical approach revolves around immanent critique, socio-diagnostic critique, and prognostic critique, each oriented around prejudicial discourses (Wodak, 2009); and, (iii) the order of discourse model refers to the discursive constitution of a social domain and the relationship between different discourses within it (Fairclough, 1998). While the cognitive aspect of discourse, such as personal prejudices, are not denied, this project is not equipped to measure these individual outcomes. For this project, Fairclough's model of CDA is most useful, for revealing examining how media discourse on private prisons is shaped by relations of power and ideology. A key feature of this method is what Fairclough calls intertextuality: "how in the production and interpretation of a text people draw upon other texts and text types which are culturally available to them" (Fairclough, 1998, p. 143). A benefit of this approach is that Fairclough's model leaves open the possibility for the adoption of further methodological frameworks, which is the focus of the rest of the chapter. This lends this research a degree of flexibility to explore the emergent discourse around human rights in Mt Eden prison.

CDA is an infamously difficult methodology to report all the rereading and reinterpretation steps involved. Retrospectively, I can distinguish two broad stages. First, a source analysis of the news texts was undertaken. This step was important for revealing the power relations that manifest in media discourse. The second step involved a framing analysis. Through a thematic inductive grounded theory analysis, 
primary news frames were identified. Within these frames, the discursive strategies used to advocate or challenge the legitimacy of private prisons were identified.

\section{Source Analysis}

The legitimation of private prisons not only deal with the issue of privatisation, but the power position of the actors involved. Power is enacted in discourse by placing certain individuals in the position to constitute the boundaries of discussion (Van Dijk, 1993). A source analysis was crucial for exploring who has the power to define the issue of prison privatisation. By measuring the sources of news articles early inferences can be made about commoditised and ideological biases within the discourse (Wimmer \& Dominick, 1994). The analytical source categories were developed inductively, using a pilot study, which allowed categories to emerge from a preliminary count of the sources. Sources were coded in ten categories as outline in Table One, with further specification of the party political sourcing under the political category. 
Table 1 Source Categories

\begin{tabular}{ll} 
Source & Description \\
\hline Political/Government & $\begin{array}{l}\text { Individuals speaking on behalf of the state/political } \\
\text { party or in their role as a politician including civil } \\
\text { servants }\end{array}$ \\
Corporate & $\begin{array}{l}\text { Individual speaking on behalf of a corporate entity } \\
\text { Unions }\end{array}$ \\
Penal Lobby Groups & $\begin{array}{l}\text { Law and order lobby groups. E.g. the Sensible } \\
\text { Sentencing Trust }\end{array}$ \\
Prison Reform Groups & NGO's that advocate for prison reform. E.g. The \\
& Howard League for Penal Reform \\
Local Representatives & Politicians or representatives of local councils \\
Māori Representatives & Those identified as primarily speaking as a Māori/Iwi \\
& representative \\
Human Rights groups & NGO's that specifically promote human rights \\
Academic & Individuals speaking as an academic 'expert' \\
Prisoners & Individuals identified as in prison or primarily denoted \\
& as a 'former prisoner' \\
Miscellaneous & Sources that do not fit into above categories \\
\hline
\end{tabular}

The miscellaneous category included any non-official sources that could not be coded into one of the other seven non-official categories, and because of irrelevance, did not warrant a special category. Thus, the "protester" is a clear example of this category but it also included, for example, religious figures.

It can be instructive, due to the inductive nature of the coding classification, to compare the schedule above to the seminal study of news sources by Sigal (1999), who asserted nine source categories: 1) Government elected, (2) Government official, (3) NGO representative, (4) NGO affiliated, (5) Unaffiliated citizen, (6) Victim, (7) Observer/Unofficial Commentator, (8) Celebrity Personality, (9) Central participant. Mapping the current study over Sigal's, we can see that there are remarkable 
similarities. Given the unique nature of prisoners' rights coverage, certain categories require further inflexion, such as separating NGO representative into Human Rights groups, Penal Reform groups and Penal Lobby groups, while others, such as celebrity, can be excluded.

Finally, determining when a citation was indeed a source was guided by the description used to describe the action of the person. For example, an individual was a source when they said something, confirmed something, or revealed something. However they were not a source if they were described in third person as performing an action.

\section{Frame Analysis}

The second stage involved a frame analysis. After identifying the main sources of media discourses, it is important to investigate how news sources instil their values, beliefs and ideas. For Mosco (1996, p. 147), “communication is taken to be a special and particularly powerful commodity because...it contains symbols and images whose meaning helps to shape consciousness". The media form the main source of socialised communication (Castells (2013, p. 157), as media has the potential to reach society at large, and to frame the public mind. Journalists limit and define the meaning of an event by selecting what is presented and what is absent in a communication, thereby shaping interpretation (Hallahan, 1999; Iyengar \& Kinder, 2010; Pan \& Kosicki, 1993). By focusing on certain concepts, frameworks or discourses, these become naturalized ways of making sense of the issue (Vaara, 2013).

For Reese (2001, p. 11), frames act as "organizing principles" which are socially constructed and negotiated over time. However, this definition is not without criticism. Entman (1993, p. 52) remarked that "framing is often defined casually, with much left to an assumed tacit understanding". Due to its acquiescence for understanding both bottom-up as well as top-down communication processes, 'framing' as a concept has become somewhat unclear, with Scheufele (1999) commenting that frame analyses is neither a full-fledged theoretical framework or a coherent methodological approach, but a number of related methods for analysing discourse. However given the various disagreements, Entman (1993, p. 51) concluded that:

...the concept of framing consistently offers a way to describe the power of a communicating text. Analysis of frames illuminates the precise way in which 
influence over a human consciousness is exerted by the transfer of information from one location - such as a speech, utterance, news report, or novel - to that consciousness.

There are many different approaches to identifying frames in the news. Entman (1993, p. 52), for example, suggests that frames can be identified by "the presence or absence of certain keywords, stock phrases, stereotyped images, sources of information and sentences that provide thematically reinforcing clusters of facts or judgments". On the other hand, Tankard (2008) offers a list of eleven framing mechanisms for identifying news frames, including headlines, quotes and conclusions.

There are two methods for identifying frames: inductive and deductive (Semetko \& Valkenburg, 2000). In the inductive approach, frames are identified in a bottom-up process from the empirical data. The advantage of this is the possibility of identifying frames previously unidentified. Deductive framing identification, on the other hand, consists of predefining certain frames and verifying the extent to which the frames occur in the sample. While this approach offers transparency, there is an inability to identify new unidentified frames. In a meta-analysis of framing studies in leading communication journals, Matthes (2007) found that $68 \%$ of framing studies used an inductive approach.

In some studies of framing the unit of analysis is the whole news article, while others identify a frame per paragraph or proposition. H. Harris (2001) argues that the unit of analysis should be chosen to be congruent with the nature of the research questions. Given the large data population and relative homogeneity of themes within individual articles, news article were utilised as the unit of analysis, determining the dominant frame in each article.

Due to the gap in the literature dealing specifically with media representations of private prisons, I was unable to begin coding with a pre-established set of codes. A preliminary analysis coding each article for the five generic news frames provided by Neuman, Just, and Crigler (1992) ${ }^{4}$, found that, although all five frames were present, they did not capture all of the articles of private prisons.

\footnotetext{
${ }^{4}$ In their exploratory study they identified 'human impact', 'powerlessness', 'economics', 'moral values', and 'conflict' as common frames used by the media and the audience.
} 
Articles were then coded for primary frames using a thematic inductive grounded theory analysis (Glaser \& Strauss, 2009). I began with open coding, a stage in which data is examined to establish tentative categories (Berg, 2001). Informed by the analysis of the dominant penological discourses in chapter three, I identified five primary frames (Table 2): 'managerial', 'less eligibility', 'safety and security', 'humanitarianism', and 'politics'. Once this working coding list of frames was established through multiple readings, each article was coded for its primary frame.

Table 2 Primary Frame Categories

\begin{tabular}{ll} 
Frame & Description \\
\hline Managerialism & A preoccupation with the management of \\
Less Eligibility & $\begin{array}{l}\text { Discussions in terms of prisoners perceived social and } \\
\text { symbolic position }\end{array}$ \\
Safety and Security & $\begin{array}{l}\text { Security and its surrogates } \\
\text { Humanitarianism }\end{array}$ \\
Focus on effect on prisoners, social prescriptions and \\
morality
\end{tabular}

Finally, for the last step, I investigated the discursive strategies used to promote or challenge private prisons. It is through discursive processes that the experience of incarceration is given meaning to the majority of the public. Legitimating strategies involve active attempts to construct a positive and convincing narrative (Golant \& Sillince, 2007). It is important to move beyond simply identifying established legitimacy "to the processes of legitimation by examining the concrete discursive practices and strategies used" (Vaara, Tienari, \& Laurila, 2006, p. 793). Borrowing from Hardy and Phillips (1999), discursive strategies are understood as the use of specific discursive tactics and the mobilization of specific discursive resources to construct private prisons.

It is also important to be wary of the ideological character of media discourse on private prisons. Prior studies have noted the neoliberal characteristics of penological discourse (O'Malley, 2008; Wacquant, 2010) and media discourse in general (Phelan, 2014; 
Preston \& Silke, 2011). Preston and Silke (2011) developed a conceptual framework for considering neo-liberal discourses in the news media based around four discursive and interconnected areas of individualism, competition, the neo-liberal state and significant silences. Individualism refers to the neoliberal concept of free choice, equality of opportunity, as opposed to equality of outcome, and subsequently, a discourse that emphasises individual responsibility. The area of competition is a moralisation of the discourse of economy. The market oriented frame, often invoked in neo-liberal discourse, relates everything to the market and assumes the liberal ideology that self-interest of individuals will produce the best outcome for society. These two areas are closely connected to the neo-liberal discourse of the state. Although neoliberal discourse explicitly opposes Keynesian interventionism on the one hand, it often promotes an interventionist state to defend the market and preserve the laws of competition (Amable, 2010). However, overall, state enterprise, minus repressive state apparatus such as the police and military, is problematized and private enterprise is promoted. Neoliberal discourses often lack concepts such as social structures, like class, race and gender, as well as potential issues that fall outside the boundaries of legitimacy set by neoliberal theory, what Preston and Silke (2011, p. 56) refer to as "significant silences." Central to these silences is the concept of "fragmented imagination" (Preston $\&$ Silke, 2011, p. 56), where issues are reported isolated from the context and in a disconnected manner.

\section{Summary and Conclusion}

In this chapter, I have outlined the methodology and methods adopted for this thesis. Rather than representing a reflection of reality, the mass media are understood to play an active role in its construction. Although journalists construct the articles, the boundaries of discussion and the use of specific legitimation strategies is likely to be heavily influenced by the discourses provided by dominant sources. The thesis uses qualitative discourse and framing analyses alongside a quantitative sourcing analysis to discuss the treatment of private prisons by newspapers. A count of the articles' sources reveals who has the power to define the private prison discussion. Textual critical discourse (Fairclough, 2013) and framing (Entman, 1993, 2004) analyses are used to qualitatively investigate the construction and legitimation of private prisons. The broad breakdown of a source count provides a useful supplementary method to the qualitative 
methods of discourse and framing analysis facilitating a comprehensive study of trends in the media treatment of private prisons, the results of which are the focus of the remaining chapters. 


\section{CHAPTER SIX: OPEN FOR BUSINESS (2009-2015)}

The routine discourse around the emergence of NZ's private prisons, in the five years before the scandal at Mt Eden prison, offers a unique opportunity for understanding the techniques of legitimation and the poverty of human rights discourses in everyday constructions of private prisons and prisoners. The major questions for this chapter are: How was the private prison debate framed, and by whom? How is the penal economy framed? Are there any critiques of the penal system either at a practical, ethical or conceptual level? How is the role of the state framed? And importantly, what significant silences are evident? To investigate these questions, this chapter will analyse the media coverage of private prisons in NZ, looking at the coverage from the tabling of the Corrections (Contract Management of Prisons) Amendment Bill on 12 March 2009 until the scandal in Mt Eden prison in July 2015.

\section{Dominant Sources}

\section{Total Sources}

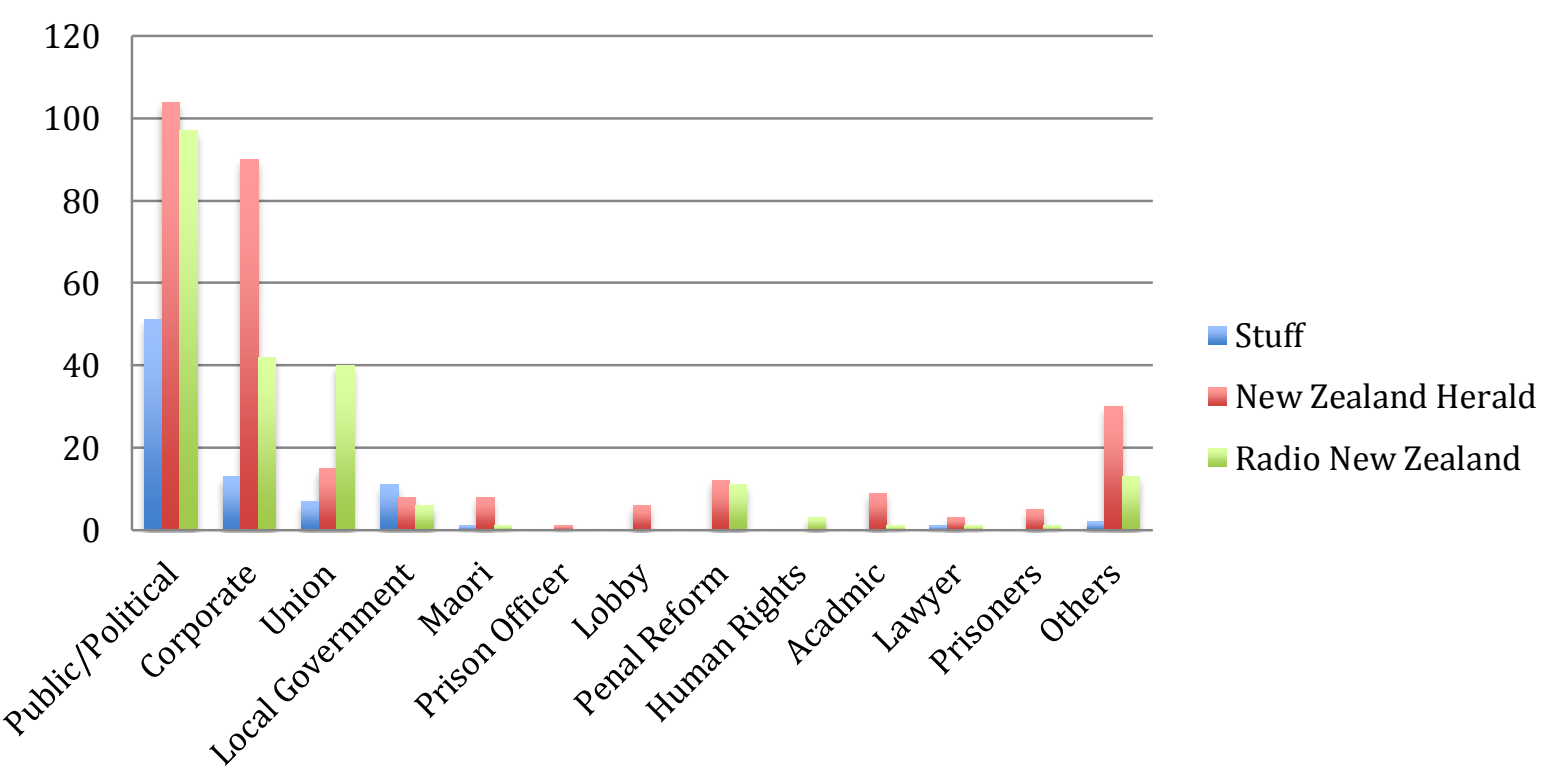

Figure 2. Total Sources by category

The use of sources on prison privatisation (Figure 2) shows that the NZ press follows the well-charted pattern of privileging authoritative voices in the news (Fishman, 1988; Gans, 1999; Sigal, 1999; Tunstall, 1970). The generally positive treatment of private prisons can at least be partly explained by the narrow selection of sources. All news 
outlets had a near monopoly of official and mainstream voices from the world of politics, finance and infrastructure, while very few sources from non-business civil society were counted.

All three news outlets were heavily dependent on political sources when discussing prison privatisation, accounting for $42.5 \%$ of total sources with $38 \%$ of articles having at least one political source. The uniformity of political representative sources across news outlets shows how easily formal power "translates into discursive power in the media, which can further strengthen the political power of an actor and ultimately lead to a self-perpetrating cycle of political influence and media coverage" (Tresch, 2009, p. 71). A further bias appears when party political representation is examined. The three news outlets had similar results: the ruling National Party comprised $60 \%$ of political sources, while opposition Labour representatives made up 25\% (see Figure 3). Interestingly, the Greens and Act party are sourced almost identically while the Māori and Conservative party are all but invisible.

\section{Total Stuff, New Zealand Herald and Radio New Zealand Political Sources Combined}

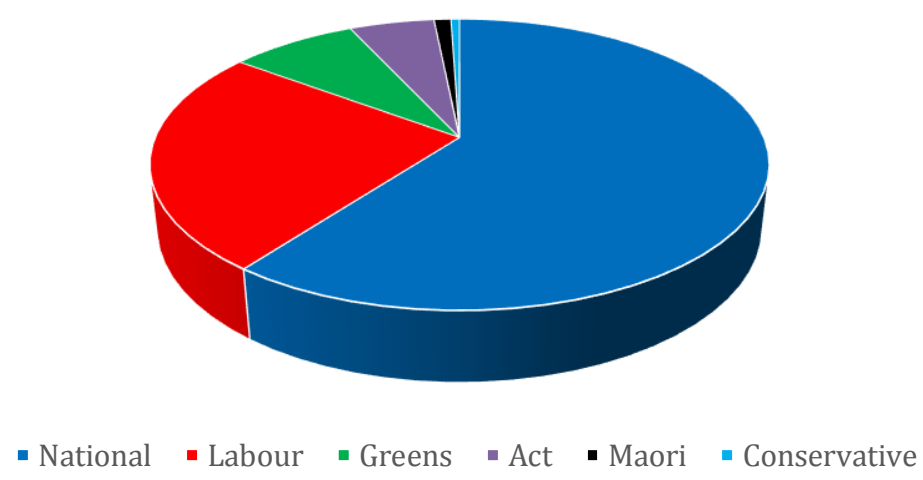

Figure 3. Total Party Political representation Stuff, NZ Herald and Radio NZ combined

The second most common sources were corporate sources, who made up $22 \%$ of the total while $25 \%$ articles had at least one corporate source. However, the NZ Herald (29\%) cited considerably more corporate sources than RNZ (17\%) or Stuff (15\%). A key observation from this research, detailed further below, is that statements about the penal system from sources in private industry tend to be reported as fact. The absence 
of critique and critical sources in response to patently partisan sources as well as a scarcity of investigative journalism reflects what Stiglitz (2011) calls the "capturing" of the press by elite sources, in which journalists internalise the values of the industry who they are supposed to be holding to scrutiny.

\section{Non-dominant Sources}

Journalistic sourcing routines, which are largely predicted on judgements regarding "reliability" and "trustworthiness" (Gans, 1999), can place particular groups of nonofficials at a disadvantage. This was pronounced in the coverage of prisoners - a powerless group who are often met with scepticism - who made up less than $1 \%$ of sources. The journalistic marginalization of prisoners may be partly explained by the difficulty in gaining access to prisoners and the pressure to meet strict deadlines, but also reflects what Foucault terms "subjugated knowledges":

... a whole set of knowledges that have been disqualified as inadequate to their task or insufficiently elaborated: naïve knowledges, located low down on the hierarchy, beneath the required level of cognition or scientificity (Foucault, 1980c, p. 82).

Against the official uncriticised popular discourse, effective criticism arises from the emergence of these local, disqualified, illegitimate knowledges (Carlen, 2008; Foucault, 1980c). The absence of this unofficial perspective in the discourse around prison privatisation acts to further camouflage the lived reality of prison under the official rhetoric of performance measures and statistical reports.

Trade unions, including the Corrections Association and Public Services Association, as well as local government representatives were less dominant but their presence indicated that the debate was primarily framed in terms of industry, economics and employment. Unions made up $10 \%$ of total sources, while local government representatives accounted for $4.5 \%$. This foreshadows that the "problem" of prison privatisation was constructed, not with prisoners in mind, but concern for the general public. While there was sporadic sourcing of NGO's and academics, these were less frequent and tended to be used as supplementary sources to established stories. Greg Newbold, for example, a Canterbury University criminologist was sourced three times 
by Radio NZ as an "advisor" to the multinational form Kalyx in their bid for the contract of Mt Eden prison. (RNZ, 2010, August 24a; 2010, August 24b, 2010, June 03)

\section{Framing Prison Privatisation}

Although reports of mistreatment at Mt Eden Prison emerged as early as 2011, it was not until July 2015 that prisoners' rights were covered in any of the three news outlets. This period of silence is significant in that "textual or journalistic meaning is communicated as much by absence as by presence; as much by what is 'missing' or excluded as by what is remembered and present" (J. E. Richardson, 2006, p. 93). The marginalisation of legitimate concern about prisoners' rights reveals an important aspect about prisoners' suffering - that it is largely invisible. While not all articles were explicit in their evaluation of privatisation, certain discursive patterns were associated with a positive or negative normative evaluation of prison privatisation and could be used as a placeholder for an explicit position. The dominant frames, as outlined in Table 2 , should be understood as a shorthand for broad regularities across news discourses. While diverging around specific positions, the frames emerge from the same set of media values, professional values, institutional pressures and political economy outlined in the previous chapter. Thus, while the following analysis stresses the difference between positive and negative evaluations of private prisons, it is important to emphasize that they share substantive common structures.

This research found only minor variations in the overall distributions of frames and themes across all three news outlets, suggesting extant and robust ideological agreement regarding the publicly understood contours of the private prison debate. The greatest proportion of articles $(62.2 \%)$ were framed in managerial terms, which is a discourse around the benefits or disadvantages of prison privatisation compared to current public prisons. The next most common frame (13.2\%) evoked strong emotive terms about public insecurity and safety. The humanitarian frame $(9.9 \%)$ was used most commonly in the negative narrative of private prisons, which chronicled clear incongruities between profit and criminal justice and rehabilitation. The political $(8.3 \%)$ discourse followed the traditional 'politics as strategy' narrative. Surprisingly, the framing of private prisons using less eligibility $(6.3 \%)$ was the least utilised frame. 
Table 3 Primary news frames 2009-2015

\begin{tabular}{lcccc} 
Frame & \multicolumn{1}{l}{ Stuff } & NZ Herald & Radio NZ & \multicolumn{1}{l}{ Total } \\
\hline Managerialism & $60.8 \%(28)$ & $68.3 \%(97)$ & $57.7 \%(101)$ & $62.2 \%$ \\
Safety and Security & $21.7 \%(10)$ & $13.4 \%(19)$ & $10.9 \%(19)$ & $13.2 \%(48)$ \\
Politics & $8.7 \%(4)$ & $4.9 \%(7)$ & $10.9 \%(19)$ & $8.3 \%(30)$ \\
Humanitarianism & $4.3 \%(2)$ & $9.2 \%(13)$ & $12 \%(21)$ & $9.9 \%(36)$ \\
Less Eligibility & $4.3 \%(2)$ & $4.2 \%(6)$ & $8.6 \%(15)$ & $6.3 \%(23)$ \\
\hline Total & 46 & 142 & 175 & 363 \\
\hline
\end{tabular}

\section{Managerialism}

Across all three news outlets, managerial frames were overwhelmingly the most ubiquitous. Managerialism has rapidly become the "new liberal discourse on crime" (Sasson, 2000, p. 250). Through core business rationalisations and managerial rhetoric, debates across all three outlets developed primarily within the "comparative efficiency" framework (Dolovich, 2009). The introduction of private prisons was not considered a question of the inherent role of the state or the criminal justice system, but "a way of delivering cost effective services with less capital" (Skellern, 2010, April 07). The initial media coverage was a celebration of rendering the penal field available for capital accumulation and the concomitant curtailment of the public-sector workforce, as a NZ Herald article titled "PPPs 'only way' to get things done," began, "New Zealand's change of government has been a signal in certain circles that we are open for business" (Slade, 2009, July 14). Although managerialism often disguises arguments of comparison as absent of ideological assumptions, this discourse was characterised by the neoclassical macroeconomic ideology of the government Roper (2011), with a focus on short term fiscal stimulus to create a fast growing, more efficient and competitive economy, as Hosking (2015, July 02) stressed, "The efficiency, the cost, the return and what we get as a result of what we want or need. Who provides that surely doesn't really matter".

Simultaneously, the NZ Herald reported that the building sector was "on its knees", surviving only through government investment in infrastructure (Gibson, 2010, August 
11a, 2010, August 11b, 2012, April 21). The introduction of PPP's, including private prisons, was later credited as rescuing the construction industry (Gibson, 2014, September 27; G. Hall, 2014, September 11). After its construction, Wiri prison was featured in Fletcher Constructions "record \$2 billion order book," with the CEO concluding:

This is good news for the construction industry, building back to the levels before the global financial crisis and it's good for the New Zealand economy (Gibson, 2014, September 27).

Revealing the mundanity with which private prisons were considered, the following exerts show how they were positioned beside roading and water infrastructure as “suitable projects" to experiment with PPP's:

Roads, water and wastewater, and prisons - three sectors of economic infrastructure where, internationally, public private partnerships (or PPPs) have proven to deliver value...PPPs have shown their worth (Weatherall, 2009, August 11).

... we need to start with a project well-suited to the PPP model, for which an international capability pool exists, and a competitive market can be created in New Zealand. We need to invest in making sure we have an informed purchaser - the Government. A tall order, but roading, prisons and social infrastructure all present opportunities for suitable projects (Callow, 2009, August 11).

This speaks to the argument, from Bourdieu (1998), that the media 'banalizes' issues, legitimating controversial issues. The coverage in the NZ Herald in particular reflected the newspaper's role as a conduit of market information, uncritically providing corporate actors a platform. Prison privatisation was an opportunity for "mum and dad investors" (Skellern, 2010, April 07), with regular articles about investment opportunities in the NZ Social Infrastructure Fund (NZSIF), based on unopposed sources from the finance and investment sector (A. Bennett, 2010, April 15; Gregor, 2010, May 04; Hunt, 2010, August 11a; O'Sullivan, 2010, May 27, 2011, August 09; Parker, 2010, March 17; Skellern, 2010, April 07). Several articles in the NZ Herald read like advertisements: 
A new avenue for investment has opened up for mum and dad investors - they can put their money into government-backed essential services for a return of about 14 per cent (Skellern, 2009, November 11).

A school or the proposed Wiri prison could be the first potential investments for a fund launched to retail investors this week (Parker, 2010, March 17).

Wellington investment banker Lloyd Morrison's Public Infrastructure Partnership (PIP) Fund yesterday welcomed news the Government will investigate the merits of a PPP model for the new prison (A. Bennett, 2010, April 15).

The non-critical nature of this reporting best reflects the media's role as a conduit of market information, in which the audience is the commodity, rather than the news article (Smythe, 1977). While some sources may be interrogated and critiqued, there appeared to be a culture of deference to private economic sources. Beyond basic information provided by the sources, these articles made no attempt to critically inform the public on economic or non-economic issues of prison privatisation.

The discourse around the effect of prison privatisation for Māori also centred on economic issues. Despite discrimination and the over-criminalisation of Māori, noted by the government and the United Nations (Te Puni Kökiri, 2011; UNHRC, 2009), prison privatisation was framed as an investment opportunity for Iwi (Hart, 2010, May 27; Hunt, 2010, August 11b). For example, in one of the few articles focusing on Māori, titled, “Iwi-state enterprises - the new vogue?" Hunt (2010, August 11b) wrote:

Maori economic leaders will target infrastructure, health, telecommunications, housing and prisons as the Government prepares to expand public-private partnerships (PPPS) in its second term. But the level of investment from the Maori sector, which has assets of more than \$16.5 billion, will depend on the ability of $i$ wi to generate cash for acquisitions from their predominantly illiquid balance sheets.

Reflecting the activity of the Corrections Association of NZ, numerous articles framed privatisation in terms of its effect on the employment of correctional officers. For example, the NZ Herald reported: 
Union leader Bevan Hanlon, from the Corrections Association, believes National's long-term goal is to privatise all of the country's prisons. He fears this will lead to a drastic loss of jobs for his members (Blackstock, 2014, April $06)$.

Individual anecdotes of the previous attempt at privatisation were used to illustrate the potential threat the development posed to prison staff, including a Corrections Officer citing a salary difference of $\$ 32,000$ in private prisons and $\$ 45,000$ in public prisons (Cheng, 2010, February 10). Closure of public prisons and associated job losses was also framed as the result of prison privatisation, such a profile of "one of Corrections Department's longest-serving and loyal managers, Peter Madsen" who lost his job after the closure of the state-run New Plymouth prison (Humphreys, 2012, November 26).

However, this narrative was soon acknowledged and rearticulated as a benefit of prison privatisation. Jay Boreham (2013, May 21), in Stuff, reported that:

Construction of the men's prison at Wiri is boosting South Auckland's economy, Serco says. So far businesses involved in building the prison have been paid around $\$ 10$ million. Around 200 people are working at the site with more being inducted daily.

The closure of state-run prisons and associated job losses was also framed as an appropriate cutback on public spending and ode to the success of the prison system. For example, in an opinion article for Stuff, John Sargeant (2015, April 18) criticised Labour MP Kelvin Davis for opposing the closure of state-run prisons in favour of new private prisons, writing: "Labour's Kelvin Davis is complaining that because of the improvements in the rehabilitation of prisoners, the prison officers will be losing jobs". This is a strong example of what Freudenburg and Alario (2007) call diversionary reframing, in which the character of the critic is attacked and their argument misrepresented. Davis had previously attacked the immorality of prison privatisation but his position was rearticulated and responded to on different terms, with Sargeant concluding, "It's not about job creation Mr Davis. It's about making a better society based on providing opportunity". In the process of attacking his character, the current 
penal system was hailed as a rehabilitative failure and private prisons were reframed as benefiting prisoner welfare.

\section{Safety and Security}

Capitalising on the fear of crime - one of the clearest forms of moral deviancy - the positive evaluation of privatisation often drew on frameworks of crime prevention, rehabilitation and security. The discourse of risk management and security, promising the protection of "us" from the threat created and represented by the external "them," paints the public as the "real" consumer of criminal justice. The focus on prisoners tended to follow the hierarchisation of newsworthiness. Celebrity prisoners, such as Kim Dotcom ${ }^{5}$ (Courtney, 2014, January 18) and Rod Petricevic ${ }^{6}$ (Leask, 2012, April 07) met the threshold for coverage in the NZ Herald as did the prisoner, Aaron Forden, dubbed "Houdini" after his escape from Mt Eden prison (Dinsdale, 2011, October 11; Edge, 2011, October 20; RNZ, 2011, October 10). The discourse was characterised by a risk management rhetoric in which the prison had failed to protect the public:

The escape has raised serious questions, with prison operator Serco and the Department of Corrections saying they were commissioning a joint review of the escape to find out what happened and what steps were needed to ensure security at the jail (Dinsdale, 2011, October 11).

Without rejecting the goals of deterrence and incapacitation, prison privatisation was also framed as a tool for rehabilitation. For example, in an article in the NZ Herald titled, "Helping prisoners to come out of the mist," Simon Collins (2015, May 06)reported that "the prison is empowering prisoners" by adopting "the responsible prisoner model":

We are encouraging prisoners to be responsible for themselves, responsible for their families, responsible for their victims, and empowering prisoners to that level of responsibility.

\footnotetext{
${ }^{5} \mathrm{Kim}$ Dotcom is a German-Finnish Internet entrepreneur who was arrested for copyright infringement in relation to his file-sharing website Megaupload.

6 Rod Petricevic is a New Zealand businessman who was found guilty of misleading investors after the collapse of his finance company Bridgecorp.
} 
By promoting new technology, 'innovative' programmes, risk assessment and, importantly, reducing recidivism the private prison was endorsed as the only way to achieve the twin goals of public protection and recidivism:

From the moment the first prisoner walks into New Zealand's newest jail at Wiri this month, prison staff will start planning for his release ... It aims to get there by helping prisoners develop positive relationships, skills and work experience both within the prison and after their release ... Kohuora includes a "cultural centre" just outside the gate providing services for prisoners' families. Parenting programmes will be offered to both the men and their families ... Controversially, the prison is empowering prisoners by giving them each a computer on which they can study and manage their appointments and even their meal menus. They will not have internet access ... At Kohuora, Open Polytechnic tutors will run classes and encourage prisoners to keep studying on their in-cell computers (S. Collins, 2015, May 06).

Confirming the primary role of the prison as a place for reducing crime, this discourse erases the prisoner as an agent with rights. Not for serving the needs of the prisoner, the private prison is considered the saviour of a failing penal regime, reducing the burden of the tax payer and protecting them from dangerous offenders.

The news coverage around prison privatisation also sporadically focused on the effect a new private prison would have on the local region. Initially, the discourse framed the local community as powerless victims to the government making decisions without consultation. For example, the construction of Wiri prison was framed in the NZ Herald (S. Collins, 2011, August 02) and Stuff (Morgan, 2012, March 13) as imposed on the local community, "which was already one of the most deprived in the country" (S. Collins, 2011, August 02). The NZ Herald reported that:

Manurewa Local Board member Colleen Brown, who chairs the Vision Manukau coalition formed to oppose the jail, said the decision was "gutting'" for a community which was already one of the most deprived in the country. "It's just one of those facts of life living in Manurewa, which means that if things happen in our community, done by people from outside the community, we get stigmatised," she said (S. Collins, 2011, August 02). 
However, this discourse evolved to frame prison privatisation as a benefit for the community, providing economic stimulation (Boreham, 2013, May 21) and employment opportunities for the region (S. Collins, 2013, August 07; Gibson, 2014, March 11; Loren, 2014, September 04). The same journalist as the previous excerpt now reported that:

Manurewa politicians have dropped their campaign against the new Wiri prison and are now trying to get as many jobs out of it as possible for unemployed South Aucklanders. The construction of the new $\$ 270$ million jail is now well under way, with 300 to 350 people working daily on the site which is next to the existing women's prison (S. Collins, 2013, August 07)

Highly consistent with certain aspects of the less eligibility doctrine, the ascendancy of concerns for the public over those in prison, and the false dichotomy which pairs them as inseparably dichotmous, highlights the understanding that prisoners forfeit their rights for the rights of the community, as Meng-Yee (2012, July 15) reported in the NZ Herald, "Burns said that ensuring public safety was the department's priority and incidents of prisoner disorder and disruption were contained and managed within the prison". This discourse taps into the neoliberal understanding of active conditional citizenship, in which those who commit a crime are excluded from equal rights and equal concern as those outside prison.

\section{Less Eligibility}

Within the discourse on privatisation, framing in terms of the impact on prisoners was rare and coverage was sporadic. Most discussions of social and symbolic hierarchy tended to be implicit rather than explicit, however, status concerns were readily apparent. This is captured by the notion that prisons are supposed to be unpleasant places, bereft of any indulgence. For example, "accusations" that prisoners in Mt Eden prison were receiving dessert every night warranted media attention because this was considered a special privilege:

The main prison guards union, the Corrections Association, says in addition to larger meals, the jail's operator, Serco, is also turning on dessert every night which is unheard of in the public prison system (RNZ, 2011, August 10). 
If prisons are not sufficiently austere, even symbolically, the state is perceived to be favouring prisoners over victims. In 2014 it was announced that Wiri prison had been given the informal name "Kohuora", translated as "coming out of the mist into the new world of the living", a name recommended by Mana Whenua iwi, Te Akitai Waiohua. In the NZ Herald, Russell Blackstock (2014, June 15) sourced a spokeswoman of the Sensible Sentencing Trust, who said: "We would like inmates to be reminded they are serving their sentences in a prison, not some kind of spiritual retreat". Reflecting the power that victims hold, the article also sourced Brian Brown, "whose 24-year-old daughter Natasha Hayden was strangled by double killer Michael Curran in 2005". Brown argued that it was "disgusting" and prisoners would be able to hide that they had spent time in prison by referring to their time in Kohuora, rather than prison.

In sympathy with these media discourses is the long standing fable of the 'folk devil' (Cohen, 2002). A "negative reputation" (Scraton \& Chadwick, 1986, p. 95) distances those in prison from deserving and respectable people and serves to discredit any appeals to sympathy. Cheliotis (2010, p. 176) found that the media restrict coverage of prisoners to the "occasional televised snapshots or single-column bulletins tucked away in the inside pages of a 'lefty' newspaper'. In line with this, the misfortune of the prisoners affected by prison privatisation was rendered benign and ordinary, predominantly by not paying any substantive attention to them. The primarily descriptive news texts were laden with facts and figures, with maximal emotional distance placed between the audience and the prisoner as their suffering failed to fulfil the criteria of relevance.

The lack of both representation and sourcing of prisoners denotes the strength of the established construction of criminality. As Jenkins (1994, p. 220) has shown, crime news construction "is a cumulative or incremental process, in which each issue is to some extent built upon its predecessors, in the context of a steadily developing fund of socially available knowledge". The mass reality of crime has evolved to the point where assumptions about crime and the response to crime are no longer questionable (Barak, 1994). The media no longer need to justify or contextualise crime news. Particular images of crime and criminals have become firmly entrenched in the mass consciousness as typifying "normal" criminality. 


\section{Politics}

When issues are framed using a political frame, they are marginalised as tools within a struggle for political legitimacy or political disagreements. Semetko and Valkenburg (2000) found that the political conflict frame tended to be more common in newspapers with a more serious reputation, which may reflect the tendency for "serious" outlets to rely on a "he-said-she-said" style of reporting in the name of balance. The political frame was utilised more so in articles from Radio NZ, comprising 10.8\%, compared to $8.8 \%$ in Stuff and $4.9 \%$ in the NZ Herald. For example, a typical (RNZ, 2012, March 08) article read:

The Labour Party says there is no evidence to support the Government's claim that the private sector can build and run prisons more efficiently than the state.

The Corrections Minster, Anne Tolley, today announced that the new Wiri prison in South Auckland will be built, maintained and operated by a consortium of private companies.

She says the prison operator will be required to out-perform public prisons by 10-per cent, with better rehabilitation and lower rates of re-offending.

But Labour's Corrections spokesperson, Charles Chauvel, says overseas experience shows that over time it is never cheaper to use private prisons.

Prison privatisation was often framed as a political conflict between the "left" and "right," with National favouring privatisation on one hand, and opposition parties, namely Labour, opposing it. The commentary in these articles often focused on the strategies of each side in realising their policies and the political repercussions that privatising prisons would have for the major political parties. Although the story of "the race" of politics is important, when strategy stories dominate the news, discussions more relevant to issues of punishment, such as human rights, are crowded out.

\section{Humanitarianism}

Although it is often touted that we live in a "golden era of human rights" (Mutua, 2016, p. 450) human rights were explicitly mentioned in only four articles during this five year period. The NZ Herald featured a brief article about prisoners being denied 
medication (Johnson, 2012, February 12); Radio NZ reported on the opposition to prison privatisation by the Human Rights Commission (RNZ, 2009, July 01b) and Amnesty International (RNZ, 2010, May 28); and Stuff briefly reported on prisoners held longer than their sentence ${ }^{7}$, referring to a source as a "human rights lawyer" (Sharpe, 2012, May 08). The article quoted human rights lawyer Tony Ellis who also provided information about the discouraging effect of the Prisoners' and Victims' Claims $\mathrm{Act}^{8}$, arguing, "Logically the situation will be getting worse because there are more prisoners. If the systems aren't improving, and they're probably not with private prisons, the likelihood of mistakes is greater."

With no explicit reference to human rights in most articles, moral criticism of prison privatisation tended to be used primarily in editorials and opinion articles. However, the moral framing of prison privatisation was also sparingly adopted in everyday news articles through quotations from the Prisoners Aid and Rehabilitation Society (RNZ, 2009, November 26b), Justice Action (RNZ, 2009, May 04), Caritas (RNZ, 2009, July 01a), Human Rights Commission (RNZ, 2009, July 01b), the Howard League for Penal Reform (RNZ, 2009, November 26a) and the Green Party (RNZ, 2010, June 08).

The foremost of these concerns relates to the inherent nature of the coercive power of the state. Delegating carceral power to private companies represents a stark break from the traditional assumptions about the state's monopoly on violence (Weber, 1946). For example, in the NZ Herald, Matthew McCarten (2009, November 29), a left-leaning political organiser, argued:

Part of being a civilised society is that the police, courts and prison are under direct public control. It shouldn't be an opportunity for shareholders to improve their wealth.

\footnotetext{
${ }^{7}$ After a Supreme Court judgement in 2016, it was announced that approximately 500 people currently imprisoned, and an unknown number since 2003, had their release dates wrongly calculated by the Department of Corrections (Supreme Court of New Zealand, 2016, September 2016)

${ }^{8}$ Prisoners' access to compensation was significantly curtailed under the Prisoners' and Victims' Claims (Continuation and Reform) Amendment Bill. Prisoners only receive compensation for mistreatment after outstanding debt, legal aid and reparations to victims are withdrawn from the sum. Ellis, and others, argued that this would act to deter prisoners from reporting mistreatment.
} 
The second form captures the idea of injecting a profit motive in to punishment, as Misa (2009, March 16) argued in the NZ Herald:

There is a danger that if you build up an industrial vested interest into the penal system, and as part of that interest they are designed obviously to keep the prison population such that it satisfies those commercial interests ... there is a risk that that distorts the penal policy that otherwise you would introduce.

Alternatively, McCarten (2009, March 15), argued prison privatisation is a false panacea, "an ideology that believes, somehow, if our services were being run by private operators then all would be well'". Similarly Kelsey (2010, August 26) argued that:

The real policy impact of private finance initiatives is quite simple - they are creative accounting exercises that disguise a massive transfer of wealth to private consortia that receive guaranteed returns with minimal accountability.

Although emphasizing different points, this discourse centred on the "right thing to do" compared with instrumental framing of the expected or actual performance of private prisons (Burkhardt, 2014).

However, this discourse around the ethics of private prisons was met with a narrative in which the mechanisms of accountability was emphasized as well as the penalties for "performance failures". The accountability discourse in all three news outlets presented largely technical and procedural accounts of the "success" or "failure" of privatisation, based on statistical discussion of services at a certain quality measured against "key performance targets" (Chapman \& Johnston, 2012, July 06; Davison, 2012, December 06, 2012, July 06, 2013, March 27; Johnston, 2012, July 06; RNZ, 2012, April 27; 2012, July 05, 2012, July 06, 2012, October 31, 2012, September 18, 2013, March 26; Speirs, 2014, August 19). For example, described as "no different to any other contract", the NZ Herald reported that:

He [John Key] believes Serco has learned from teething troubles he encountered during his time at Mt Eden. By its second year in charge, Serco had vastly improved its performance and was meeting 95 per cent of the targets set for its six-year deal (Blackstock, 2014, April 06). 
Andrew (2007) argues that the increasing use of performance measures, financial reports and audit investigations excludes questions of morality, appropriateness, or risk to prisoners through technical processes. The regurgitation of this technical discourse in the media invites the audience to see "failed performance targets" rather than abuse of people.

\section{Conclusion: Establishing Legitimacy}

There was a clear bias in the use of sources and lack of critique in the narratives provided by them. By relying on sources deemed authoritative, whether intentional or not, reporters tended to "systematically echo the judgments and perspectives of the power elite" (Schiller, 1981, p. 123). The appearance of balance and objectivity was achieved through pairing soundbites from political parties in a 'he said she said' style of reporting, quoting left wing politician $\mathrm{A}$, and then quoting right-wing politician $\mathrm{B}$, about subject matter X (Cunningham, 2003). Of the critical voices that did appear, their character was often discredited and their support of prisoners was questioned. For example, external critics were framed as having "criminal class sympathies" (B. Jones, 2013, November 05), while self-interested "heavily unionised guards" refused to cooperate with the national interest (Gower, 2009, November 02, 2009, September 24). These "ideologically driven" (Holmes, 2009, March 15) critics stood in the way of economic progress and rehabilitation (Sargeant, 2015, April 18). Penal authorities were thus able to establish a "regime of truth" (Foucault, 1980b, p. 133). The absolute lack of prisoner's representation in the media reflects, what Wolfsfeld (1997, p. 24) calls, "the principle of cumulative inequality" - that those who most need news coverage find it the most difficult to obtain it.

As a result, the three news outlets shared a common set of penological logics, which manifested in a broadly positive evaluation of prison privatisation. Capturing the general sentiment of the discourse, Holmes (2009, March 15) asked:

As for private prisons, who knows? Does it really matter who owns them, any more than it matters who owns the telephone company? In the famous words of Deng Xiaoping, 'what does it matter the colour of the cat as long as it catches mice?' 
Dolovich (2009) argues that the narrative of comparative efficiency, the most common manifestation of the managerialism frame in the privatisation debate, is presupposed by the idea of privatisation itself. By steering debate past the point where the role of the state is questioned, critiques of privatisation on grounds other than efficiency have little success at influencing the debate (Dolovich, 2009).

Facing a certain level of critique on both political and moral grounds, in order to assert and establish legitimacy, Serco engaged with, what Carlen (2002b, p. 79) calls, "prisonlegitimating reform". In response to scepticism, the newly forged self-image of the private prison in NZ was a regime legitimated by its provision of programmes, treatments and therapies, the underlying justifications for which mesh well with common-sense rhetoric of those who oppose the private prison, about the need to devictimise and rehabilitate prisoners. Moreover, many of the new programmes received the blessing of the organizations which had previously put forward radical critiques of privatisation. For example, in an "official nod", Simon Collins (2011, August 02) reported that the local iwi, Ngati Te Ata, supported the new Wiri prison, quoting iwi member Tahuna Minhinnick:

"It's on our ancestral land. We've spent our life objecting to it,"” he said. "But in our first engagement with the Department of Corrections, they asked us under what conditions would we support it. Our response was the kaitiaki plan".

In accordance with the discourses that legitimated the prison, the media also participated in the social organization of silence and talk (Sutton and Norgaard (2013). Just as significant as the discourses that the media shine a light on, are the ones out of sight. Cultural practices (e.g., not asking questions, preferring not to be told information, using euphemistic speech) contribute to the disregard of certain elements, such as human rights violations. Hurrelmann et al. (2009, p. 21) found that referring to the protection of human rights was one of the most frequent techniques of legitimation in media discourses indicating that they were "gaining ground as core foundation of legitimacy". However, for Freudenburg and Alario (2007, p. 147), "legitimacy is not only constructed openly, but "may be achieved most efficiently by keeping public attention focused on other topics". It appears that this process of legitimacy

\footnotetext{
${ }^{9}$ The kaitiaki plan is a proposed programme to provide environmental training to Māori prisoners.
} 
management is easily malleable to the media, rendering the issue of legitimacy through human rights "less observable" (Freudenburg \& Alario, 2007, p. 154).

Thus, in terms of human rights reporting, this period can be characterised by what Joye (2010) calls "neglected news." In absolute and relative terms, there was very little coverage of prisoners' human rights across the three news outlets. Instead, by emphasising almost every other aspect and diverting attention towards mischaracterising critics, the legitimacy of private prisons was established. By focusing on the comparative efficiency of the public and private sector and remaining agnostic to the proper function of the state, the positive evaluation of private prisons developed the appearance of unbiased value neutrality (Dolovich, 2009). 


\section{CHAPTER SEVEN: IT'S A JUNGLE, AND INSIDE ARE ANIMALS (2015-2016)}

Once privatisation is affirmed as appropriate and legitimate, the view that prison officials, through the state, have particular obligations to those in prison is replaced by a view of prison officials as managers, are obliged only to carry out their assigned responsibility as efficiently as possible (Dolovich, 2009). As seen in the previous chapter, once this displacement has occurred, debate about whether privatisation is the best way to achieve the obligations to those we punish, or what those obligations are, becomes marginalised. The strength of the "thought style" (Douglas, 1986, p. 12) of comparative efficiency, subsumes alternative frames and dampens the discourse around human rights.

However, one of the most critical phenomenon of the modern polity is the remarkable prominence and potency of the politics of scandal (J. B. Thompson, 2000). Scandals thrive on wall-to-wall coverage in the media, and politicians devote extraordinary time to controversies about matters of moral and legal impropriety. Scandals often uncover systemic failures and norm violating behaviour (like the repeated breaching of human rights) and thereby help to define what behaviour is appropriate or legitimate (Klotz, 1995). As such, scandals are a unique type of discourse - a struggle about the legitimacy of ideas, norms, actors, institutions or whole political systems.

The Mt Eden scandal was a newsworthy story: immediacy, drama, personalisation and continuing novelty. As Matthews (2015, July 25) reported in Stuff, “The back-and-forth about Auckland houses and Labour racism was rapidly eclipsed by a genuine, meaty political scandal. What has been going on in the privately-run Mt Eden Prison?" This "critical discourse moment" (Chilton, 1987, p. 12) provides an opportunity to understand the culture of human rights, and how it relates to the legitimacy of private prisons. 


\section{Dominant Sources}

\section{Total Sources}

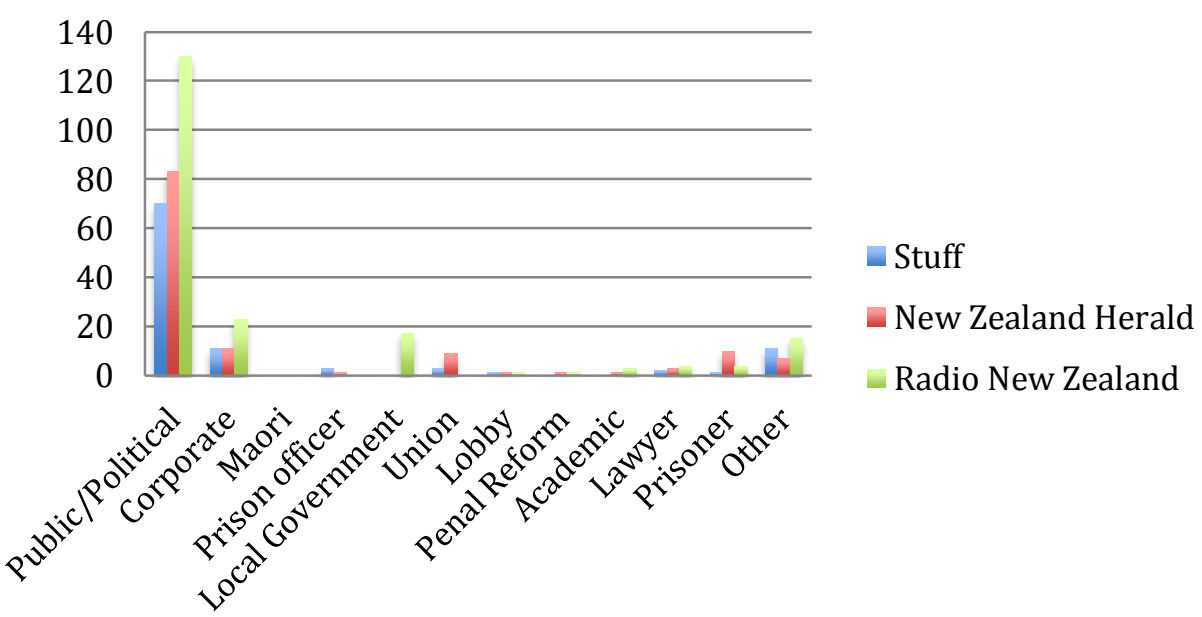

Figure 4. Total Sources by Category

Political sources remained the most frequently sourced group making up almost double the total sources compared to the previous period. Political/public sources comprised $68 \%$ of total sources in Stuff, $65 \%$ in the NZ Herald and 64\% in Radio NZ, while $65 \%$ of all articles had at least one political/public source (see Figure 4).

National Party members comprised 53\% of political sources, while Labour made up $37 \%$ (Figure 5). The change in ratio, in favour of Labour, reflects the involvement of Labour Party Minister Kelvin Davis who played a critical role in the revelations at Mt Eden prison. When compared, Stuff and the NZ Herald have a roughly similar ratio of party political representation, while Radio NZ had a more equitable ratio. While this appears to reflect a tendency towards balanced reporting, this reflects a concentration of sourcing to elites rather than wider sourcing (Hallin, 1994). As Schudson (2003, p. 150) argued, "there is little doubt that the centre of news generation is the link between reporter and the official". 


\section{Total Stuff, New Zealand Herald and Radio New Zealand Political Sources Combined}

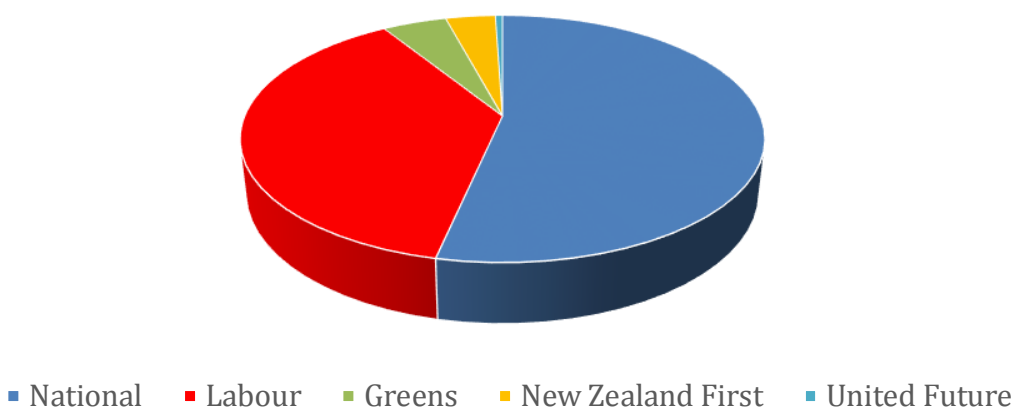

Figure 5. Total Party Political representation Stuff, NZ Herald and Radio NZ combined

\section{Non-dominant Sources}

Where previously, no segment of the prison population was judged as informed or credible enough to be granted news space, the prisoners now served to build on the definitions of the problem already identified and established by, more trustworthy, political sources. Although not a dominant source, prisoners were sought by journalists more so after the Mt Eden scandal, comprising 3.5\% of sources (15) compared to less than $1 \%$ (6) before the scandal. Gans $(1999$, p. 81) argues that "those who lack power are... generally not sought out until their activities produce social or moral disorder news" and W. L. Bennett (1990, p. 106) suggests that non-official sources are only included when they "express opinions already emerging in official circles". Furthermore, when they do appear, it is often in the context relating to illegal acts, undermining their credibility and legitimacy.

Judges, the police, and legal professionals were the major credible voices for prisoners, as Dastgheib (2015, July 24) reported in Stuff:

Lawyer Kelly Ellis said Mt Eden prisoners from Whangarei, some of whom were her clients, were scared to go back to the Serco-run facility for fear of being repeatedly beaten up. 
Although the scandal prompted journalists to recalibrate and broaden the range of sources for issues related to private prisons, they rarely directly contacted prisoners themselves, preferring surrogates with a more credible reputation. Of the other categories local government representatives made up 3.9\% of total sources followed by unions $(2.8 \%)$. No other category of sources made up more than $1 \%$ of total sources, indicating the concentration of media power.

\section{Framing the Mt Eden Scandal}

Although there had been several previous reports of violence in both privately and publicly managed prisons, it was the tangibility of visual evidence that served as the catalyst to break the silence around the treatment of prisoners. As Barthes (1981, p. 76) famously said, "in photography I can never deny that the thing has been there." The video evidence, Stuff (2015, July 22) argued, invited "the public into a major prison" and gave authenticity to incidents of violence, stabilizing what might otherwise not have been acknowledged. Radio NZ (2015, July 21) reported that while fighting in prison was "nothing new," it was "harder to dismiss because there is video footage". The importance of visual evidence was noted six months later in the NZ Herald, when Little (2015, December 06) reported, "Whether or not the fighting continues in real life, the record is still there on YouTube for anyone to see".

The NZ Herald described the footage as showing "jailed gang members fighting, and others apparently taking drugs, drinking homemade alcohol and using a prison guard's walkie-talkie" (Maas, 2015, July 19). This made potent material for the media and served as the basis for a series of news stories over the following six months. The continual supply of newsworthy revelations including reports of "droppings" (in which prisoners are dropped from a balcony), organised fighting involving staff, suicides, inaccurate reporting of incidents, and transferring injured prisoners to public prisons to satisfy performance requirements meant there was continuous coverage in the media and led to Stuff concluding that there was "a broad feeling that something is wrong here - and that even prisoners have a right to basic bodily safety" (N.A., 2015, July 22).

As shown in Table 4, the greatest number of articles were again framed in managerial terms $(41.4 \%)$. However, where previously the second most common frame was safety and security, the scandal provided space for coverage of the lived experience and 
mistreatment of prisoners and thus the humanitarian (36.9\%) frame was the second most common frame. The political discourse $(9.5 \%)$ was the third most common, followed by safety and security $(6.6 \%)$. Finally, the least utilised frame was less eligibility (5.6\%).

Table 4 Primary news frames 2015-2016

\begin{tabular}{lcccc} 
Frame & Stuff & NZ Herald & Radio NZ & \multicolumn{1}{l}{ Total } \\
\hline Managerialism & & & & $41.4 \%$ \\
& $37.1 \%(23)$ & $27.8 \%(20)$ & $49.7 \%(75)$ & $(118)$ \\
Safety and Security & $6.5 \%(4)$ & $6.9 \%(5)$ & $6.6 \%(10)$ & $6.6 \%(19)$ \\
Politics & $17.7 \%(11)$ & $12.5 \%(9)$ & $4.6 \%(7)$ & $9.5 \%(27)$ \\
Humanitarianism & & & & $36.9 \%$ \\
& $33.9 \%(21)$ & $38.9 \%(28)$ & $37.1 \%(56)$ & $(105)$ \\
Less Eligibility & $4.8 \%(3)$ & $13.9 \%(10)$ & $1.9 \%(3)$ & $5.6 \%(16)$ \\
\hline Total & 62 & 72 & 151 & 285 \\
\hline
\end{tabular}

\section{Managerialism}

The frame of managerialism remained dominant, however the rhetoric changed considerably. Initially, the response by the government to revelations of dropping ${ }^{10}$, was to deny they ever took place:

The allegation sparked an angry response from Corrections Minister Peseta Sam Lotu-Iiga who accused Davis of "making it up" and claimed he was using the young man's death for political gain (Watkins, 2015, July 21).

Mr Lotu-Iiga angrily accused Mr Davis of repeating hearsay, making false allegations, and defaming the minister with comments he had made earlier this week about violence at the Mt Eden prison (Davison, 2015, July 22).

\footnotetext{
10 "Dropping", refers to an initiation ritual where prisoners were thrown over a balcony to the concrete below.
} 
In a statement, Corrections Minister Peseta Sam Lotu-Iiga said neither he, Corrections nor Serco had heard of "dropping" (Fisher, 2015, July 22).

However, as Cohen (2013) notes, literal denial is often futile in the face of real evidence. Thus, following the cumulative and sustained coverage of the scandals, the violence, fighting, and corruption in Mt Eden were primarily framed using the technical language of "satisfying contracted performance requirements" and "contract breaches" punished by "fees" and "fines", as Stuff reported:

Serco will lose more than half a million dollars for failures to keep inmates safe inside Mt Eden Prison. Corrections chief executive Ray Smith said he had signed off "a number of performance notices to Serco for failings at Mt Eden Corrections Facility" on Monday, the first day Corrections was back in charge of the prison since "stepping in" (N.A., 2015, July 27).

This managerial-speak is not merely a stylistic effect. The dry and calculative discourse works to suppress the violent effects of the prison and of prison privatisation, re-frame human suffering as an organisational cost, and distance the state from the consequences of the event. This is embodied in the focus of the financial loss for human rights violations:

Failing to control prisoners to ensure a safe jail cost Serco $\$ 50,000$, unlawfully mixing inmates cost $\$ 100,000$, not meeting incident reporting targets and other contractual requirements cost $\$ 150,000$, according to the news agency. The biggest fine given to Serco was more than $\$ 315,000$ for failing to keep serious assaults down (N.A., 2015, September 09).

The NZ Herald continued to feature articles proclaiming the benefits of private-public partnerships, including for prisons. An article titled, "Golden age for infrastructure" is an apt example of the decontextualized nature of the reporting. Reading as an advertisement for Fletcher Construction, the NZ Herald reported:

Fletcher Construction chief executive Graham Darlow says the next five to 10 years are set to be the golden age of New Zealand infrastructure investment... Darlow says it isn't just roads and water. There are now a number of social 
infrastructure projects in the pipeline with fresh spending on schools, prisons and hospitals (B. Bennett, 2015, August 20).

This reflects what Preston and Silke (2011, p. 56) call "fragmented imagination", that is the separation of business and politics in press reportage. Despite the prominence of the scandals, arguably the most noteworthy event at the time, there were no mentions of the human rights scandals, in moral or managerial terms.

The quest for responsibility followed similar technical, measurable and procedural rhetoric. Discourses of accountability influence "our beliefs about who, what and how accounts of events are to be given and received" (Andrew, 2007, p. 5). Although the state is traditionally portrayed as the "operational instrument of savagery" in human rights violations (Mutua, 2001, p. 202), the involvement of private contractors significantly obfuscated state culpability (Jamieson \& McEvoy, 2005). Despite the ultimate authorization to contract out punishment coming from the NZ government, as the private operator of Mt Eden prison, Serco's role was primarily in question.

Where traditionally, accountability in the prison system was driven by public law values of political and legal accountability, under managerial discourses, accountability has come to be associated with market discipline and financial accountability (Lazarus, 2004), as the following excerpts show:

Smith said "substantial" financial penalties were also possible, and he would await the outcome of reviews under way before proceeding further. Other options available include issuing Serco with a final warning or early termination of the contract (Gulliver, 2015, July 25).

Mr Lotu-Iiga says he is holding the company to account over the incidents, but he will wait for an investigation before reviewing its contract (RNZ, 2015, July $17)$.

John Key says the Government could impose financial penalties on Serco for any breaches of its contract (RNZ, 2015, July 20).

These calls for financial accountability and market discipline were mirrored across all three outlets. At the root, Loughlin (1992, p. 260) argues, managerialism is "driven and 
fashioned almost entirely by political economic impetus and with virtually no legal or constitutional consciousness". When accountability relies on purely technical dimensions, denying ethical elements, the expectations of what can and should be done are limited to superficial fiscal and contractual sanctions.

\section{Humanitarian}

The largest difference in media coverage before and after the scandal was the increase in humanitarian framing with concern for prisoner welfare. Here, several discussions of the wider negative implications of privatisation emerged and, briefly, the unwavering recourse to incarceration was questioned. An editorial in Stuff, for example, highlighted the common-sense business-like accountability discourse: "Serco has flown in top brass and conducted cell searches... there is talk of penalties if the government can find the right clause in its contract". Questioning the "alarming" (N.A., 2015, July 22) rate of violence in Mt Eden prison, the editorial questioned the extent of deceit by Serco, calling for an investigation, independent of the government.

In the NZ Herald, Kerry McIvor, a radio talk-back host, wrote of what she called "Yet another shameful stain on this country":

This should not be happening. Being locked up is punishment enough. Inmates shouldn't have to live in daily fear of violence. Yet if you lock up hundreds of men and keep them in close proximity to one another, with little to do and inadequate supervision, violence is inevitable (McIvor, 2015, July 26).

Several journalists pointed to the scandals as evidence of the illegitimacy of private prisons. In an article titled, "Running our prisons like a Monty Python skit", Jane Bowron (2015, July 27) wrote that, "The Government has been constitutionally reckless in privatising prisons because only the state can take away the liberty of its citizens, not a private, profit run business, and an overseas one at that". Similarly, Oscar Kightley, a NZ actor, noted the problem of motivating incarceration economically:

The goal of most private companies is to make a profit. One of the ways to maximise profit is to minimise costs. That could involve cutbacks, and there are always consequences as a result of that, both good and bad. But applying that model to a prison seems crazy. Punishing and rehabilitating the members of 
our community who have fallen foul of the law is a serious and important task. One that should remain the preserve of the Government (Kightley, 2015, July 26).

Beyond questioning the legitimacy of private prisons, an article in the NZ Herald, highlighted the restrictive and exclusive nature of the comparative efficiency framework, writing:

But let's not get sidetracked by the present furore over Mt Eden Prison into a debate over who should be running our prisons. The more basic scandal we should concentrate on is our ongoing predilection to crowd more and more young men - about 50 per cent Maori - behind bars in the first place (Rudman, 2015, July 29).

Outside of editorials, substantive coverage utilising the humanitarian frame largely relied on those speaking on behalf of prisoners, rather than the prisoners themselves. For example, a lawyer representing prisoners, Kelly Ellis, provided an "authoritative" counter-voice to describe the conditions within the prison:

Ms Ellis said lawyers were regularly asked by "black-eyed prisoners" to delay their cases so they could stay in Northland's Ngawha Prison instead of being sent back to Mt Eden. She said every lawyer she had spoken to confirmed the repeated complaints from clients about violence, adding: "Serco is the most dangerous prison from a prisoner's perspective. It's the prison I feel most worried about visiting, particularly now" (Priestley, 2015, July 24).

Ms Ellis says she's often asked by clients to try for a short remand period so they'll be sent to Ngawha near Kaikohe, rather than Mt Eden, because they fear the violence there (RNZ, 2015, July 23).

Ellis said Serco did not have the staffing levels to manage the prison effectively and said she believed the level of corruption there was making things unsafe (Dastgheib, 2015, July 24).

The NZ Herald did use direct accounts from ex-prisoners in two articles to describe the reality of imprisonment. One unnamed ex-prisoner described: 
The inmate who served time on violence charges says the worst beating he received in prison was as he woke in his cell. He says it was far worse than the attacks which he had dished out resulting in his convictions and his time in prison. He could barely see out of pulped eyes, had a broken nose and a jaw which is still out of shape many months later (Fisher, 2015, July 25).

These direct accounts from prisoners were able to describe the brutal reality of prison and the ambivalence of prison officers:

He claims he was told by a senior prison official that "nothing is going to happen" so there was no point in complaining. "It was swept under the carpet" (Fisher, 2015, July 25).

Amidst the debate there were very few voices explicitly acknowledging the rights of prisoners. One article in Stuff was explicitly framed in terms of human rights. Chris Trotter wrote:

The problem with making prisons profitable in today's world, however, is that the State has an internationally mandated duty of care towards all incarcerated persons. Regardless of whether a prison is publicly or privately run, its inmates have rights that must be acknowledged and enforced by the people in charge. Unfortunately for profit-seekers, human rights cost lots of money (Trotter, 2015, July 28).

The article was an attempt to begin a conversation on private prisons and punishment explicitly using the language of human rights. Trotter (2015, July 28) outlined the historical context of the prison system in detail, concluding:

The unfolding scandal at the Serco-managed Mt Eden Corrections Facility, while shocking, is only one aspect of the under-resourcing crisis afflicting our entire prison system. Yes, the privately-run facility is chronically under-staffed. And yes, the State does appear to be covering up some of its deficiencies. But many of our state-run prisons are equally under-resourced. The State's duty of care is being called into question on a daily basis - in both the public and private sectors. As citizens of a civilised nation, we have a duty to care about what is being done, in our name, behind prison walls. 
Burkhardt (2014) argues that there are only a finite amount of frames that resonate with the public. Hence, although Trotter attempted to bring the discussion about private prisons within a human rights frame, outside of this article, the human rights frame remained marginalised by the dominance of alternative discourses.

It is interesting to note, and indicative of the potency of the discourse, that the notion of less eligibility often underpinned coverage in favour of the rights and safety of prisoners. An editorial in the NZ Herald, titled "If we can't show decency for jail inmates, do it for their kids" wrote:

Most of the inmates in our prisons aren't nice people, or good people. But the sentences we impose on them - sentences decided by the parliaments we elect and the judges we appoint - are of jail time. We do not sentence them to violence, brutality, inhumanity. To do that would be to disavow our own human decency... we must protect the rights of even the worst criminals in our prisons - if not for them, then at least to show our children the meaning of decency and humanity (Milne, 2015, July 26).

Because prisoners do not meet the criteria for sympathy, the partners and children of deceased prisoner Wayne Hotton were used to frame the event more sympathetically. In the "latest horror story to emerge from the Auckland central remand prison", Loren and Wall (2015, July 26) reported, Hotton's partner was now "raising the couple's 3year-old daughter, Eden, by herself". Not necessarily a critique of the article itself, it highlights that journalists are aware of how prisoners are commonly understood.

\section{Less Eligibility}

The discourse of less eligibility and the narrative of the 'other' was, again, not particularly prevalent, but the rhetoric was explicit. The use of this frame was the most obvious point of difference between news outlets, with Radio NZ (1.9\%) utilising this discourse far less than Stuff (4.8\%) and NZ Herald (13.9\%). The point in these stories is that because prisoners are dangerous and deviant they have forfeited their rights to humane treatment. Hudson (2006) used the metaphor of the "monster," to describe how the media construct the archetypal criminal. Almost a caricature of itself, the NZ Herald wrote of the Mt Eden prison, "It's a jungle, and inside are animals" (Fisher, 2015, July 
25). In one of the most explicit uses of this frame, Savage (2015) began an article in the NZ Herald:

The inmate found dead in his Mt Eden prison cell had admitted violence and sex charges against women and children spanning a period of four decades. The Herald can reveal the prisoner was Liberty Charles Baker, 63, who was due to be sentenced in the High Court at Whangarei this week after pleading guilty to nearly 80 charges including rape, sexual violation, assault, kidnapping, threatening to kill and grievous bodily harm.

The general impression conveyed by this reporting is that the violence, death and suffering were a necessary risk that prisoners knowingly take on when breaking the law. Consistent with the individualism that characterises the criminal justice doctrine, media accounts of the scandals tended to focus on the individual acts, locating the origins of them inside the traits of the perpetrator. Tracy Watkins, of Stuff, concluded an article, quoting the Corrections Minister that:

It should also be remembered, however, that prisons were a place for violent people. "We are dealing with some of the most dangerous, some of the most violent people in our community and that's why they're behind bars" (Watkins, 2015, July 21).

When the scandal initially broke, the NZ Herald began, "Fights in a prison are probably not unusual, and often worse than the "fight club" video from Mt Eden that has had a political chain-reaction" (N.A., 2015, July 29). An opinion article by Labour Minister Phil Goff, criticising the mistreatment of prisoners, included a reply by Corrections Minister Judith Collins, who said:

But serious, violent criminals are dangerous and unpredictable people. Managing adversarial groups of prisoners in a prison environment is extremely difficult, whether it's a public or privately managed prison. Their learned behaviour does not change simply because they have had a change in location from outside to inside. (J. Collins, 2015, July 26)

The "prisoner," who is rarely identified and personified, is constructed as a homogenous group of "violent people", which implicitly constructs as 'other' anyone 
who has contravened the law. In this sense, the prisoner is reduced to their criminal offending role. The definition of the prisoner was highly restrictive, referring largely to dangerous, drug using gang members. The NZ Herald and Stuff employed this frame with dramatic language, emphasizing rampant drug use and violence:

Welcome to the jungle -- the Mt Eden Correctional Facility. In this private universe violence is a part of daily life and drugs are freely available (Fisher, 2015, July 25).

New footage from inside a New Zealand prison has emerged online - this time seemingly of a murderer performing in music videos filmed in a jail cell. The revelation comes in the same week footage emerged showing jailed gang members fighting, and others apparently taking drugs, drinking homemade alcohol and using a prison guard's walkie-talkie. (Maas, 2015, July 19).

The footage also show prisoners drinking alcohol, taking drugs and playing with a guard's walkie talkie (Howe, 2015, July 22).

The 'prisoner' label and the associated processes of othering set up a dichotomy based on the idea that experience of victimisation and offending are incompatible (Drake \& Henley, 2014). Thus, the construction of the prisoner was punctuated by a discourse of good and respectable people who helped shape the contours and further solidify the "otherness" of the prisoner. A number of articles explicitly discussed the scandals in relation to the victims of crime unrelated to the incidents in prison, based on the idea of a criminal justice system that "favoured" offenders:

From the victim's perspective, it's absolutely distressing to think that would happen. From a public perspective it's even more alarming that our prison system has become so offender friendly that this type of stuff is able to go on (Maas, 2015, July 19).

Later contributions dismissed the idea of compensation for prisoners, on the basis of their previous offences. For example, in a NZ Herald article titled "Give compo for killer to kids: victim's family", Edge (2015, July 28) reported: 
Any compensation a Northland murderer gets for being left with brain damage after an assault in the Serco-run Mt Eden prison should go to his two children, their grandmother says. [...] "Why is this about money for him? It's his intentional actions that have cost us, the victim's family and tax payers. Then there is the cost of life of his children's mother and you can't put a price on that," she said.

Using the plight of victims within debates on the rights of prisoners is a troubling tactic, and highlights the zero-sum logic of victims' rights and prisoners' rights. Such strategies indicate a tendency to stifle any debate about human rights of those who are not "ideal victims" and indicate a more general apathy for the proper scrutiny of prisoners' issues.

\section{Safety and Security}

Given the emphasis on the unpredictability of prisons and the susceptibility to violence, it is not surprising that a discourse of risk and security was also emphasised. This coverage, while noting the relationship between the violence and increased prison population remained uncritical of the criminal justice policies that have led to the overcrowding. Rather than question the heavy reliance on incarceration, such representations typically problematized the apparent lack of control and security, as demonstrated by the activities that were revealed:

The picture painted by the unfolding Mt Eden debacle is of a prison that is badly understaffed and at crisis point (Watkins, 2015, July 25).

If prisoners can set up their own fights in their cells and even in full view in the exercise yard, then the staff are patently not doing their job and overseeing the inmates properly - that is if there are sufficient warders to carry out the duties properly (Burrows, 2015, July 22).

The Corrections chief executive, Ray Smith, visited Mt Eden today and says the biggest complaint is staff rosters not being properly filled, which means less ability to deal with any problems (RNZ, 2015, July 27) 
The NZ Herald reported that "Mobile phones are banned in prisons and it was unknown how the footage made its way online" (Tait, 2015, July 18). This set the scene for the following week, which focused on a review of "the adequacy of controls designed to address prisoner violence and access to cell phones in other New Zealand prisons" (Kirk, 2015, July 19). The revelations were as much a scandal for the access to a cellphone as the violence itself, as the following excerpts show:

Prisoners' phone usage should be closely vetted, and for good reason. That these prisoners were able to smuggle in cellphones means they could also use them to harass the public and, in particular, their victims (Howe, 2015, July 22).

The use of cell phones, which seem to have been used to make the videos, in prison is prohibited and those involved could face internal or police charges (Walters, 2015, July 16).

Taxpayers have forked out $\$ 17$ million on cellphone jamming technology for prisons - but inmates continue to be caught with increasing numbers of contraband mobile phones (Shadwell, 2015, July 23).

Because the government was able to rearticulate the problem as a lack of security, restoration framing became increasingly frequent, typically involving the control of contraband and articulating Mt Eden as an outlier event. By confiscating contraband cell phones, Serco were able to claim that they had "done something" about the problem:

A cellphone has been found in a search of Auckland's Mt Eden prison following allegations of fight clubs and prisoners being dropped off balconies. Serco, the private operator at Mt Eden, initiated a full search of the prison on Monday and managing director Scott McNairn told Radio NZ about 50 per cent of the search had been completed (Moir, 2015, July 22).

Similarly, attention to the problem of understaffing deflected attention from other, more pertinent, systemic-wide problems with the prison system in general. By framing the problem as a lack of staff, when the government introduced a "crack team" of staff, they were able to claim that they had squashed the problem: 
On Friday afternoon Corrections chief executive Ray Smith and Corrections Minister Sam Lotu-Iiga announced a "crack team" of up to 20 staff from around the country would oversee the day-to-day running of the jail for the immediate future. (Gulliver, 2015, July 25)

As noted in the second chapter, the retreat to securitization is a familiar response to penal scandal (Bartlett, 2009; Carlen, 2002a). Increased security is understandable from a legitimation strategy perspective. The scandals not only called into question the moral legitimacy of private prisons, but also kindled suspicion regarding the instrumental legitimacy of privatisation. The moral propriety of institutions are easily undercut (Suchman, 1995) and establishing moral legitimacy of private prisons, in particular, is difficult (Burkhardt, 2014). On the other hand, the quelling of feelings of anxiety through increased risk measures, however brief, has proved a reliable tool for securing legitimacy (Pratt, 2016).

\section{Politics}

The political conflict frame emerged towards the end of the coverage. One result of the scandal was an investigation undertaken by the Chief Inspector in to the fights at Mt Eden, as Stuff reported:

An investigation into organised inmate fighting at Auckland's Mt Eden prison has been extended due to the "volume" of issues raised. Corrections chief executive Ray Smith said on Thursday the frames of reference and the timeframe had been extended, with a final report on the first part of the investigation to be completed by October 30 (N.A., 2015, August 27).

Up to this point, the media had focused primarily on the contractual and fiscal threats that Serco faced as well as detailing the various scandals. However, on completion of the investigation, Serco challenged the final report in the High Court:

Private prison operator Serco has started its legal challenge... saying the investigation relied on anonymous allegations and went beyond its terms of reference (Sachdeva, 2016, Fenruary 15). 
As a result, the majority of coverage in the beginning of 2016 was framed as a conflict between the Department of Corrections and Serco. The allegation that "Corrections had breached natural justice by refusing to provide it with notes from interviews conducted during the course of the investigation" (Sachdeva, 2016, Fenruary 15) established the foundation on which the debate would take place. Within this 'political' frame, the coverage focused on the political consequences within NZ, rather than the incidents themselves or any effects on the prisoners.

\section{Conclusion: Re-establishing legitimacy}

Moyn (2010) notes that the recent triumph of human rights discourses has led to the discussion of various political issues and events under the banner of human rights. The point, Powers (2016, p. 323) writes, is that what constitutes "human rights news" is always up for negotiation. The scandals in Mt Eden offer an example of a moment in which counter-discourses can, however briefly, reframe a penal issue and fracture the legitimacy of the prison system. The perspectives that were previously suppressed, disqualified, or silenced due to their 'inferior' status were now granted new significance. The deployment of these discourses, particularly from prisoners, signified an expansion to the limits of what could be said about punishment, and by whom. While still concerned about upholding a "hierarchy of credibility" (H. S. Becker, 1967), the media included subversive and sceptical discourses, questioning the government's strategy of prison privatisation and the treatment of prisoners.

However, the ease with which legitimacy was established for private prisons provides a cue to the ease with which it could be re-established. This speaks to the strength of the common-sense ways in which punishment and crime are talked about and the heavy reliance on mainstream political and corporate sources in the mass media. The constructions of victimhood and criminality are tightly bound to power, as Lukes (1974, p. 123) notes, "for power is everywhere, precluding liberation and imposing regimes of truth". Even before the media filters discourses or whole events, the accounts of penal events that reach us do so only through a series of filters in the different levels of government, from the prison officers and managers to political ministers. Inevitably, politicians and criminal justice officials have an investment in maintaining a certain version of the world (Chermak, 1997). 
When we find that there is friction between different narratives, without explicit evidence for either, it is not surprising that journalists fall in to the temptation of preferring "authoritative" sources. Although there was a slight reconfiguration of the calculus of credibility, the public are socially predisposed to perceive prisoners as essentialized, “dangerous others", not like us (Drake, 2011, p. 367). When offenders themselves make claims of victimhood, the strength of dominant constructions constrains the possibilities for alternative representations or ways of talking about or identifying the 'problems' of prisons (Drake, 2011). Indeed, in their study of news coverage of corrections, Welch, Weber, and Edwards (2000, p. 260) concluded that the "media discourse on corrections provides opportunities for high-ranking government figures to institutionalise their authoritative position". In the Mt Eden case, although the YouTube videos provided somewhat of a direct window into the prison, government sources shifted from literal denial to implicatory denial (Cohen, 2013). The government, and by extension the media, marginalised the victims (Watkins, 2015, July 21) and attacked their critics (Fisher, 2015, July 22), "condemning the condemners" (Cohen, 2013, p. 61) using a discourse of necessity, trivialisation and less eligibility that trivialised the mistreatment. The various rights abuses was justified because prisoners are understood to forfeit their rights when imprisoned (J. Collins, 2015, July 26).

This speaks to the active nature of legitimacy management (Suchman, 1995). It is not a surprise that the re-establishment of legitimacy largely mirrored its formation, as Suchman (1995, p. 597) wrote, "the task of repairing legitimacy resembles the task of gaining legitimacy". In the wake of a scandal, although critical journalists were able to provide a counter-frame of humanitarian concern for the protection of prisoners, these were subsumed under managerial and security discourses provided by political sources. The immediate strategy to mend legitimacy involved a normalizing account that distanced actors from wrongdoing and reaffirmed the importance of the secure prison as an institution (Hearit, 1995).

After the perfunctory spectacle of literal denial, the state acted to separate the illegitimate parts of the organization from the legitimate. Political actors may be criticised and ultimately replaced with new ones without fundamentally altering, or even questioning, the legitimacy of higher political objects (Hurrelmann et al., 2009; 
Suchman, 1995). The Minister of Corrections Sam Lotu Iiga, who inherited the policy of privatisation from the previous Minister, absorbed the most amount of criticisms and acted as a scapegoat for the scandal. At the same time, while the Department of Corrections invoked the "step in" clause of the contract, taking over the prison's management, this was advanced as an individual aberrant case. In fact, despite the social and economic costs associated with the scandals, the fact that the government was able to take over management of Mt Eden prison was put forward as evidence for the superiority of the privatisation model, as Prime Minister John Key told Stuff:

In a funny kind of way it shows it works because we've got a contract and the contract allows us to do something you could never do with a Government department, and that is to say we're not going to renew the contract, certainly not under the conditions we negotiated (Sachdeva, 2015, December 09).

The government was able to confront challenges to the legitimacy of private prisons, isolate the legitimate from the illegitimate and discursively redeem them by denying the reality that generated the 'problem' in the first place. 


\section{CHAPTER EIGHT: DISCUSSION AND CONCLUSION}

This thesis investigated discursive legitimation processes through which politicians, journalists and other social actors negotiated the human rights scandals in Mt Eden prison. Bringing together insights from critical discourse analysis, it focused on the media as an important arena for public legitimation of controversial state activities. Overall, a managerial frame was consistently found across the three news outlets with a source bias towards mainstream political and corporate interests. Despite the substantial power of the scandals to undermine public confidence in the prison system and the mantra of private sector efficiency, it is evident that it can be difficult to recognise increased securitization as anything but a legitimate and necessary response to problems of the prison, no matter how the problem is defined. Thinking about crime and punishment has been significantly restricted by a dominant narrative that reduces responses to crime as a contest between tactics and techniques of prison management (Loader \& Sparks, 2016). In an era in which the government has reduced the social and economic insurances guaranteed to citizens, the introduction and increase of risk control measures offers one of the last remaining assurances that the state is in control (Pratt, 2016).

Legitimacy involves several dimensions. Suchman (1995) distinguishes between pragmatic legitimacy, involving calculations of self-interest; moral legitimacy, based on judgements of "the right thing to do"; and cognitive legitimacy, based on what is taken for granted. The veracity with which pragmatic legitimacy was pushed by the government speaks to the very contentious nature of prison privatisation in NZ. While the limited research on public opinion of prison privatisation from the United States has found an ambivalence in the general population (F. W. Becker \& Mackelprang, 1990; L. Thompson \& Elling, 2000), both the media discourse and submissions to the Law and Order Committee, discussed in the introduction, indicate considerable dispute. Targeting the general fiscal and safety anxieties, pragmatic legitimacy was emphasised through a discourse of cost-efficiency and crime-reduction capabilities of privatisation.

Suchman (1995, p. 582) also talks of a legitimacy based on cognition rather than on interest or evaluation. Legitimacy on this view stems from the most potent cultural models that furnish plausible explanations for private prisons in what is a "chaotic 
cognitive environment" (Suchman, 1995, p. 582). Thus, in addition to the deliberate strategies used to establish legitimacy, one of the most important aspects is the underlying assumptions in legitimating discourse - "the unsaid" (Vaara, 2013, p. 10). The privatisation debate was contextualised within "the moral and fiscal failure" of the state run penal system (Rudman, 2015, July 29). Although this may appear as a challenge to the legitimacy of the state, it provides a zero-sum logic: by pointing to the weaknesses of public institutions, the relative legitimacy of the private prison is enhanced (Dolovich, 2009). The absence of discussion about alternative solutions, reflects the taken-for-granted neoliberal suspicion of state provided welfare, particularly for prisoners (Bell \& Scott, 2016; Humpage, 2014; Vaughan, 2000).

One of the key reasons that the legitimacy of private prisons was so easily established initially, I suggest, is less to do with efforts to construct affirmative beliefs in the moral legitimacy of these practices but an active attempt to ignore or rearticulate them (Freudenburg \& Alario, 2007). The counterpoint to active strategies of legitimacy, silence, can fulfil a crucial legitimating role (Sutton \& Norgaard, 2013). In his study of the legitimacy of private prisons in the United States, Burkhardt (2014) found that privatisation was adopted more often in States where it was discussed in instrumental rather than moral terms. The overwhelming majority of discourses before the human rights scandals focused on everything but moral considerations, simply ignoring the critical moral discourses. As Pynchon (2012, p. 251) wrote, "If they can get you asking the wrong questions, they don't have to worry about the answers".

While expressing concern for prisoners, critical discourses were also shaped and defined by deeply embedded assumptions about the prison. One of the most potent frames that restricted critique was the notion of less eligibility. The process of othering, essential for engendering the principle of less eligibility, easily translates into support for punitiveness (Vasiljevic \& Viki, 2014). Othering acts not just to justify the privatisation of prisons, but defines the boundaries of the moral community and reinforces the "just world principle" - the belief that those in prison deserve to be there (Crelinsten \& Schmid, 1993). Placing prisoners outside the social and moral community "erodes ... responsibility for understanding and challenging the individual and social forces that have produced such an ... event" (Jackson, 1995, p. 4). 
Habitually divested from taking responsibility for prisoners, prisoners themselves are deemed responsible for their own safety and rehabilitation (Bell \& Scott, 2016). This was encapsulated in an article in Stuff, titled "Prisoners have a choice about their futures" (Howe, 2015, July 22). After documenting the violence, Howe (2015, July 22) wrote:

The 20 men who live in this unit have clearly done bad things to be put there in the first place. They have lost their freedom as a result but this is no excuse to wallow in self pity or slump into the anti social behaviour that got them there. Prisoners, like anyone else, can still make choices to improve their lives. [...] Such a disciplined regime will hopefully imbue them with the work ethic and sense of responsibility necessary to operate effectively in the outside world.

The focus on individual responsibilities provides a framework to ignore state or societal responsibility for prisoners' suffering. Because "the community" has been afforded a 'victim' status in and of itself, prisoners, understood as inseparably antagonistic to victims, are not viewed as deserving of sympathy (Carrabine, 2004). This moral disengagement, Waller (2008, p. 155) notes, "is not simply a matter of moral indifference or invisibility. Rather, it is an active, but gradual process of detachment by which some individuals or groups are placed outside the boundary within which values and rules of fairness apply".

Although the press expressed demands for reform, these were expressed in managerialspeak, such as fines and contract "step-in clauses". This discourse was highly coded, full of reference to performance indicators, contracts, risk, security, and the desire of the government to investigate the causes through "a 'robust and thorough' review over footage of inmates engaging in banned behaviour in New Zealand prisons" (NZME, 2015, July 19). It is no surprise that there was an absence of debate about radical alternatives to the proposed sanctions, such as criminal sanctions for the executives of Serco, retraction of the government's policy of privatisation, decarceration or abolitionism. In essence, the message was that the prison system was broken but there is no alternative. No transformation of the penal system is considered viable and the solution became simply to fine Serco and take over management of one of the prisons that they were managing. In this way, the media appears to act more as a release of frustration and discontent rather than a forum to explore potential alternatives. 


\section{Journalism and the Power of the Image}

The implications of this research for $\mathrm{NZ}$ journalism are unsurprising considering the long standing literature on news production, journalism and the literature on crime journalism (Barak, 1995; Blakely \& Bumphus, 2005; Cheliotis, 2010; Chermak, 1995; Gies, 2015; Jewkes, 2015; Lumby, 2002; Mason, 2006, 2009; Pratt, 2007, 2008a; Reiner, 2007; Sparks, 2000a; Surette, 2015). First and foremost, Stuff, NZ Herald and Radio NZ were found to rely on an extremely limited group of sources; the sources were drawn almost exclusively from positions of power, whether political or economic. Given the narrow choice of sources, it is unsurprising that the dominant frames followed narrow managerialism and security. The skewed treatment of what should be important societal issues as a result of the day-to-day common-sense frames and absence of substantive critique cannot be understated. The corporatized and statefunded media outlets both showed strengths and weaknesses. The state-funded news outlet, Radio NZ, while restricted to the same PR releases and elite political sources, did not promote the advertorial-like business/financial stories in Stuff and NZ Herald. However, the corporatized media appeared more likely to invest resources in investigative reporting when the issue showed promise of profit.

What is most striking about the Mt Eden case is the existence of the visual representation of the organised fights and, relatedly, the ability to freely access the material on the Internet. New media technology has made visible what was previously kept hidden and unknown from the public (J. B. Thompson, 2005). The single video had the powerful effect of placing doubt over the previous years of denial and rhetoric that had represented Mt Eden prison as a bastion of innovation and rehabilitation. Zelizer (2010) argues that language has traditionally held a privileged role in journalism, supported by a visual component. However, this research points to the growing importance of the visual element of news. Indeed, visual 'evidence' may be a necessary condition for recognition of prisoner mistreatment. As Sliwinski (2011, p. 58) notes:

The very recognition of what we call human rights is inextricably bound to an aesthetic experience. The conception of rights did not emerge from the abstract articulation of an inalienable human dignity but rather from a particular visual encounter with atrocity. 
The visual image has played a significant role in uncovering human rights violation all over the world, from the police brutality against Rodney King in America in 1991 to the more recent Arab Spring uprising in the Middle East. However, the new democratised communications technologies, particularly the internet, has facilitated a new visibility of those previously in "spaces out of sight and out of touch" (Bauman, 2000, p. 39).

This also points to the growing mix of amateurs and professionals in the production of human rights news (Powers, 2016). Previous research has explored the importance of eyewitness videos in countries characterised by strict censorship regulations, such as Myanmar (Brough \& Li, 2013). Parallels can be made between these strict regulations and the totalizing conditions of the prison. The YouTube videos underscored the reach of the new technologies and the new possibilities for visibility these offer, even within a highly securitized prison that has a $\$ 17$ million cellphone jamming system. This usergenerated content was captured outside the professional routines of the mass media and provided the most disruptive critique of the dominant discourses. The 'gap' in public knowledge between the official discourses and the "irrefutable evidence" (Fitzharris, 2016c, p. 1) of the YouTube videos could not plausibly be filled by the same discourses that were revealed to be so violently at odds with the videos.

\section{Official Investigation of the Chief Inspector}

The government was forced to respond to critique after sustained media coverage. The Chief Executive of Corrections established an investigation by the Correction Department's Chief Inspector, on 27 August 2015. On 2 October 2016, the result of the official enquiry of the Chief Inspector was released to the public. The Chief Inspector of Corrections Andy Fitzharris (2016a, 2016b, 2016c) published two reports and a table of recommendations.

The inquiry, with access to both the Serco operational and management staff and prisoners, had a systemic reach. The report concluded that the main 'problem' was a failure of security, and it reported that there had been five confirmed fight clubs, two "probable" fight clubs, and 12 incidents of sparring (Fitzharris, 2016a). The investigation involved interviews with prisoners who reported that they feared if they refused to engage in the organised fights they would become the target of gang violence. The Inquiry blamed the staffing model: 
This model was fundamentally flawed as there is documentary evidence that the staffing roster used included some staff who were on annual leave, medical leave, or had resigned. This resulted in an inaccurate picture of the actual level of custodial staff available to ensure the Daily Operational Risk Matrix operated effectively (Fitzharris, 2016a, p. 4).

The report confirmed that contraband, including cell phones, drugs and tobacco, was freely available, with prisoners citing the prison staff as the primary source of contraband. Of note, because there was no media coverage of it at the time, the report also found that prisoners had been "denied their fundamental right to telephone calls to their legal adviser for significant periods of time: in some instances they have waited up to 5 weeks" (Fitzharris, 2016a, p. 4). This was the only mention of prisoners' rights, although the Inspector did mention the contractual 'rights' of the Department of Corrections to conduct an audit and to take over management of the prison. Hence, rather than locating the prison within the broader socio-economic or political context, the problem was located as a pathologised prison population and lazy institutional culture.

D. G. Scott (2009) argues that although official enquiries are presented as open and independent of government, they constitute official penal discourse "from above", defining and setting the boundaries of the problem and the means of resolution. They limit the damage of scandals, however they cannot provide a complete whitewash (D. G. Scott, 2009). Instead, they acknowledge criticism and rearticulate it within the official discourse (Carlen, 2002a, 2013). The solutions recommended by the Inspector were thus predicated on the problem of securitisation. The Inspector recommended: increasing staff numbers, increasing cell searches, further training so that "staff are competent in the proper procedures and are sufficiently trained in using detection equipment", identifying "key operational risks", taking disciplinary action in regards to incidents of violence, and the establishment of a national gang strategy to focus on managing gangs in prisons (Fitzharris, 2016c, pp. 2-3).

According to Burton and Carlen (1979, p. 48) official enquiries seek to dispel doubt and remedy legitimacy deficits by representing "failure as temporary, or no failure at all, and to re-establish the image of the administrative and legal coherence and rationality". The inquiry into Mt Eden prison was accompanied by an analysis of 655 
incidents of prisoner on prisoner violence in public prisons, which found that there was "no evidence that organised prisoner fighting was happening at any of the eight Corrections Services prisons we visited" (Fitzharris, 2016b, p. 2). This highlights the way in which managerial discourse, particularly the "comparative efficiency" (Dolovich, 2009) logic dominates the prison system. Notwithstanding the fact that the report found 655 incidents of violence in eight prisons over five months, because there were no 'organised' fights and the rates of unorganised violence was comparable across the prisons, the main criticism was the "poor quality of incident reporting" (p.2). Under the logic of comparative efficiency, what matters is difference (Dolovich, 2009). The similarities, such as rates of violence, tell nothing about the relative merits of public over private prisons, and thus offer no grounds for deciding between them (Dolovich, 2009). The 655 incidences of reported violence over five months in the public prisons were thus, not offered to confirm that there are serious problems across the entire prison system, but a way to neutralize concern for violence as irrelevant.

Central to the report was the cooperation of the prisoners. Although the prisoners' voices were given a privileged position, they were interviewed only on the three issues established by the Chief Executive of Corrections: organised fighting, security, and contraband (Fitzharris, 2016a, p. 1). In this way, the boundaries of discourse were safely restricted to risk, security and managerialism. It is also worth noting the ways in which the prisoners' perspectives were de-legitimated and undermined both by Serco and the Chief Inspector. First, Serco challenged the investigation because the Chief Inspector has taken oral evidence from prisoners anonymously, citing that "prisoners are extremely nervous about the possibility that any statement will be attributable to them" (SNZL vs. CIC, 2016, p. 34) and thus feared retaliation both from other prisoners and staff. Serco said they doubted the credibility of anonymous claims and allegations and that the "report is a breach of natural justice" (p. 4). Secondly, the statements made by prisoners on the availability and source of contraband, of which 10 were included in the final report, included a footnote by the Inspector that they "may have been exaggerated" (Fitzharris, 2016a, p. 58).

In sum, the Inquiry and subsequent report provided a clear opportunity for carceral clawback (Carlen, 2002a). By controlling the definition of the problem, the significance of evidence and the release of information, the government was able to say that they 
had stepped in, identified and fixed the "problem", in itself evidence for the something of the processes of accountability in arrangements with private prisons.

\section{Penal Experts}

The official report speaks directly to the power granted almost solely to authorities in establishing the 'truth' (Foucault, 1980a). With ownership over the 'official' discourse about the meaning, causes and solutions of the prison scandals, the state essentially exercises discretion in gathering evidence, conducting the enquiry, selecting witnesses, and attaching significance to evidence and recommendations. The release of the report, released almost a year after completion and to little media coverage, also points to the wider control political elites have over the release of information. The coverage of private prisons overwhelmingly relied on political and government leaders over other news sources. Becker's (1967, p. 241) model of "hierarchy of credibility" proposes that governing elites have the power to "define the way things are". Becker argued that, because credibility and authority are connected with the mores of society, the belief in the credibility of news sources has a "moral quality" (Becker, 1967, p. 241). The media provides additional opportunities for those in power to institutionalise their authoritative position, through framing the discussion as well as controlling the flow of information.

It is worth making note of the differences in what constitutes 'penal experts' from previous research, particularly on penal populism. In her thesis on the rise and power of penal populism in NZ, Bartlett (2009) found that the Sensible Sentencing Trust, a law and order lobby group, were structurally and culturally advantaged in establishing the definition and significance of crime news events. Conversely, international research has found that the police are the key definitional force for the crime news agenda (Ericson et al., 1987; Loader \& Mulcahy, 2001a, 2001b; Schlesinger \& Tumber, 1994). In the UK, for example, Loader and Mulcahy (2001a, 2001b) argue that the rise of the police chief as 'cultural agents' has afforded police chiefs with the authority to frame particular issues.

In the current study, the concentration of corporate actors as news sources reflects the prejudice for stories on privatisation. It is interesting to note that before the rights scandals in Mt Eden prison, the presence of an active labour union for prison guards 
provided the strongest countervailing narrative against privatisation. The third largest category sourced about private prisons (see Figure 1), behind political and corporate sources, union sources provided the clearest and most tenacious distinction between public and private management of prisons. The Sensible Sentencing Trust, on the other hand, appear to have lost cultural significance and favour with the media, even inviting derision for their punitive reactions. Of course, further research considering a more comprehensive research corpus is necessary to make conclusive inferences about the significance of the SST. However, the most stable trend across news outlets and during the entire span of reporting was the concentration on state authorities in the media, reflecting a firm grasp on media power in NZ.

\section{Conclusion}

A broad consensus exists that the mid to late 1980s represented a major turning point in the history of post-war punishment in NZ (see Pratt \& Clarke, 2005). Policy-making, previously underpinned by penal-welfarism, became vulnerable to populist influences. The punitive turn in the late decades of the $20^{\text {th }}$ century invited an unprecedented growth in the prison population. The "moral and fiscal failure" (Rudman, 2015, July 29) of the prison system provided an ideal breeding ground for the introduction of privatisation (McCulloch \& McNeill, 2007). While depicted as innovative and rehabilitative enterprises, the realities of private prison operations in NZ have been challenging.

The Mt Eden scandals provided "a liminal moment" (Sparks, 2000b, p. 137) that revealed the dissimilarities between prisons and other organizations. Not only did it raise difficult questions about the division of responsibility between the Department of Corrections and Serco, but it also forced attention to society's obligations to those it incarcerates. After the revelations of human rights violations, the primarily rationalistic and pragmatic legitimation struggle was transformed into a moral one that fundamentally changed the basis through which prison privatisation was contested and negotiated. This shift was characterised by an increased willingness by journalists to judge prison privatisation through universal ethical values, with more than double the rate of articles framed in humanitarian terms. 
On the basis of this research, three broad points can be made. First, legitimacy of the prison is not negotiated in a vacuum. This collection of discourses demonstrates the ways in which political, economic, and social contexts affects the significance of human rights for judgements of legitimacy. Various theories of legitimacy argue that conceptions of illegitimacy include illegal actions and unfair treatment by criminal justice power-holders, inequality of outcomes within the criminal justice system, and conflicting values between power-holders and the audience (Beetham, 1991; Bottoms $\&$ Tankebe, 2012; Burkhardt, 2014; Weber, 1946). Any number of these examples was readily apparent in Mt Eden prison, even before the scandals. In a climate in which crime and punishment have become emotionally charged, "the main positions in penal philosophy are condemned to irrelevance" (Pettit, 2002, p. 449). Even if human rights are a core value of NZ, there are a range of values available to political actors such as "moral indignation, solidarity with victims, concerns for personal and community safety, fear of the 'Other' and so on" (Snacken, 2015, p. 413). Rather than rooted in one set of unified principles, politicians grasp at any contradictory rational that offers the promise of legitimacy, manifesting in a volatile and irrational mess of prison law (D. Scott, 2013).

The second point is the vital importance of the media for accountability and transparency of the prison system. Despite the increasingly muted fourth estate function, it is only when the media shine a light on the problems of the prison, do they come to the attention of the public. The overwhelming majority of people have no direct contact with the prison. While punitive attitudes seem widely held, they are malleable, particularly when people are given more information about particular cases and offenders (Bradley et al., 2011; Hough \& Roberts, 2004). My sample of seven years of media output on prison privatisation exemplifies this view of a media discourse that supports the necessity of the prison, but also, given access to information unadulterated by political officials, can promote sympathy for prisoners and reform of the prison.

Finally, the ultimate privileging of security and its surrogates over concerns for prisoners' rights speaks to the disconnection of rights protections from what is loosely described as a human rights culture (Lazarus, 2004). Human rights provide a means to distinguish between the legitimate use and the abuse of public power. However, without a rights culture the language of human rights is malleable and the government is able 
to disregard the rights of its own citizens. Rights are wholly unrecognised or unprotected, but the language and significance of human rights is more vulnerable to the whims of the powerful (Stammers, 1999, p. 986). Rather than developing out of a long historical struggle that now binds "us" as a political community, human rights have become associated with privileged liberal activists and groups who inhabit the social fringes (Loader, 2007). Those on the periphery of the social and economic hierarchy become the target of political and media opprobrium: lawyers, professional activists and penal reformers are deemed as having the luxury of insisting on rights without having to live with the consequences, while prisoners, the homeless or other 'deviant' groups are perceived as directly jeopardising the safety of the public. Rights are thus thought of as a barrier to the protection of "us" from "them", likened to gambling with people's safety (Loader, 2007), or an organizational risk (Whitty, 2010). In this context, security and risk controls have become a vehicle for performances of legitimacy, which do not in fact represent a threat to human rights but a rebalancing of the sympathy and 'privileges' granted to prisoners.

Overall, the thesis concludes that, while fragile, the legitimacy of the penal system is deeply resilient to scandals of rights violations. This speaks to the prison's unique synonymy with security and safety and the public's ambivalence to prisoners more generally. The counter-hegemonic discourses show moments of disruptive success in fracturing public discourse, particularly in moments of scandal, but "the power of common-sense discourse inheres in its ability constantly to adapt to oppositional discourses" (Carlen, 2013, p. 224). The idiosyncratic arrangement of discourses in the media can also be partly attributed to the institutional and organizational demands of corporatized media. The time and resource constraints means journalists increasingly rely on political sources, who they have daily access to, or pre-prepared PR releases. The tabloidization of the news media has a distorting effect, over-reporting certain types of crime, and quickly moving to the next scandal before informed public debate can take place. Indeed, the commonality with which any transgression becomes a prima facie scandal may in itself have facilitated the eventual indifference. While the Mt Eden scandals momentarily fractured the legitimacy of the prison, political actors easily managed these before they were eventually forgotten. 
This is evident a year after the scandal, after the dust has settled and the media has largely moved on. Three months before the end of 2016, the date of the Department of Corrections target to achieve a $25 \%$ reduction in re-offending, the government announced that a billion dollars would be spent building new prison facilities and an extra $\$ 1.5$ billion in operating costs over five or six years (Davison, 2016, June 02; N. Jones \& Young, 2016, October 18). Unavoidable, according to the Deputy Prime Minister; the prison 'muster' increased by 700 inmates in 2016, and would be necessary to accommodate a forecast growth of 1800 new prisoners (N. Jones \& Young, 2016, October 18). The new prison planned for Waikeria, to be built and maintained by a public-private partnership, would provide new jobs, stimulate the economy, and was a sign that the government was "deadly serious about family violence and methamphetamine" (Leslie, 2016, October 18). The increase in the prison population, despite no similar growth in crime, was not a reason for concern according to the Corrections Minister: "People are in prison because they should be in prison" (Davison, 2016, June 02). 


\section{REFERENCES}

Alexa. (2016). Top Site in New Zealand. Retrieved from www.alexa.com

Altheide, D. L. (2006). The Mass Media, Crime and Terrorism. Journal of International Criminal Justice, 4(5), 982-997.

Amable, B. (2010). Morals and politics in the ideology of neo-liberalism. Socioeconomic review, 9(1), 3-30.

Amnesty International Aotearoa New Zealand. (2009). Submission to the Law and Order Select Committee on the Corrections (Contract Management of Prisons) Amendment Bill 2009. Retrieved from www.parliament.nz

Andrew, J. (2007). Prisons, the profit motive and other challenges to accountability. Critical Perspectives on Accounting, 18(8), 877-904.

Apodaca, C. (2007). The whole world could be watching: Human rights and the media. Journal of Human Rights, 6(2), 147-164.

Ashforth, B. E., \& Fried, Y. (1988). The mindlessness of organizational behaviors. Human Relations, 41(4), 305-329.

Barak, G. (1994). Between the waves: Mass-mediated themes of crime and justice. Social Justice, 21 (3 (57), 133-147.

Barak, G. (1995). Media, Society, and Criminology. In G. Barak (Ed.), Media, process, and the social construction of crime: Studies in newsmaking criminology (pp. 3-48). New York: Garland Publishing

Barthes, R. (1981). Camera lucida: Reflections on photography (R. Howard, Trans.). London: Macmillan.

Bartlett, T. (2009). The Power of Penal Populism:

Public Influences on Penal and Sentencing Policy from 1999 to 2008. (Master of Arts), Victoria University of Wellington, Wellington.

Bauman, Z. (1997). Postmodernity and its Discontents. New York: New York University Press.

Bauman, Z. (2000). Social uses of law and order. In D. Garland (Ed.), Criminology and social theory (pp. 23-45). Oxford: Oxford University Press.

Becker, F. W., \& Mackelprang, A. (1990). Attitudes of state legislators toward contracting for public services. The American Review of Public Administration, 20(3), 175-189.

Becker, H. S. (1967). Whose side are we on? Social Problems, 14(3), 239-247.

Beetham, D. (1991). The legitimation of power: Issues in political theory. New York: Palgrave Macmillan.

Bell, E., \& Scott, D. G. (2016). Reimagining Citizenship: Justice, responsibility and non-penal real utopias. In E. Bell \& D. Scott (Eds.), Non-Penal Real Utopias Foundation (2016) Volume of Justice, Power and Resistance (pp. 53-72). London: EG Press Limited.

Bennett, A. (2010, April 15). \$100m of Super could go to jail. New Zealand Herald. Retrieved from www.nzherald.co.nz

Bennett, B. (2015, August 20). Golden age for infrastructure. New Zealand Herald. Retrieved from www.nzherald.co.nz

Bennett, W. L. (1990). Toward a theory of press-state relations in the United States. Journal of communication, 40(2), 103-127.

Benson, R. (2004). Bringing the sociology of media back in. Political communication, 21(3), 275-292. 
Berg, B. L. (2001). Qualitative Research Methods for the social sciences (4th ed.). London: Allyn and Bacon.

Blackstock, R. (2014, April 06). Crime and punishment in corporate hands. New Zealand Herald. Retrieved from www.nzherald.co.nz

Blackstock, R. (2014, June 15). Poetic name for private Wiri prison slammed as 'potty'. New Zealand Herald. Retrieved from www.nzherald.co.nz

Blakely, C. R., \& Bumphus, V. W. (2005). The print media's portrayal of the private prison. Probation Journal, 52(1), 69-75.

Boltanski, L. (1999). Distant Suffering: Morality, Media and Politics (G. Burchell, Trans.). Cambridge: Cambridge University Press.

Boreham, J. (2013, May 21). Local companies benefit from prison build. Stuff. Retrieved from www.stuff.co.nz

Bottoms, A. (1995). The Philosophy and Politics of Punishment and Sentencing. In C. Clarkson \& R. Morgan (Eds.), The politics of sentencing reform (pp. 17-50). Oxford: Clarendon Press.

Bottoms, A., \& Tankebe, J. (2012). Beyond procedural justice: A dialogic approach to legitimacy in criminal justice. The journal of criminal law and criminology, 102(1), 119-170.

Bourdieu, P. (1998). On Television (P. P. Ferguson, Trans.). New York: The New York Press.

Bourdieu, P. (2005). The political field, the social science field, and the journalistic field. In R. Benson \& E. Neveu (Eds.), Bourdieu and the Journalistic Field (pp. 29-47). Cambridge, UK: Polity Press.

Bowron, J. (2015, July 27). Running our prisons like a Monty Python skit. Stuff. Retrieved from www.stuff.co.nz

Bradley, T., Rowe, M., \& Sedgwick, C. (2011). Not in my Backyard? Crime in the Neighbourhood. The Howard Journal of Criminal Justice, 50(1), 34-51.

Brough, M., \& Li, Z. (2013). Media Systems Dependency, Symbolic Power, and Human Rights Online Video: Learning from Burma's" Saffron Revolution" and WITNESS's Hub. International Journal of Communication, 7, 281-304.

Brown, D. (2008). Giving Voice: The Prisoner and Discursive Citizenship. In T. Anthony \& C. Cunneen (Eds.), The critical criminology companion (pp. 228239). NSW, Australia: Hawkins Press.

Brown, M. (2009). The Culture of Punishment: Prison, Society, and Spectacle. New York: New York University Press.

Brown, M. (2013). Penal Spectatorship and the Culture of Punishment. In D. Scott (Ed.), Why Prison? (pp. 108-124). United Kingdom: Cambridge University Press.

Bruhn, A., Nylander, P.-A., \& Lindberg, O. (2016). Swedish 'prison exceptionalism'in decline: trends towards distantiation and objectification of the Other. In A. Eriksson (Ed.), Punishing the Other: The Social Production of Immorality Revisited (pp. 101-123). New York: Routledge.

Burgess, J. (2014). What Makes News Online: A New Zealand Perspective. (Master of Management ), Massey University, Palmerston North.

Burkhardt, B. C. (2014). Private Prisons in Public Discourse: Measuring Moral Legitimacy. Sociological Focus, 47(4), 279-298.

Burr, V. (2015). Social Constructionism (3rd ed.). New York: Routledge.

Burrows, D. (2015, July 22). Caught on camera antics consistently causing consternation. Stuff. Retrieved from www.stuff.co.nz 
Burton, F., \& Carlen, P. (1979). Official Discourse: On Discourse Analysis, Government Publications, Ideology and the State. London: Routledge.

Callow, P. (2009, August 11). Is New Zealand open for business yet? New Zealand Herald. Retrieved from www.nzherald.co.nz

Carlen, P. (2002a). Carceral clawback: the case of women's imprisonment in Canada. Punishment and Society, 4(1), 115-122.

Carlen, P. (2002b). Women's imprisonment: Models of reform and change. Probation Journal, 49(2), 76-87.

Carlen, P. (2008). Imaginary penalities and risk-crazed governance. In P. Carlen (Ed.), Imaginary penalities (pp. 1-25). Devon, UK: Willan Publishing.

Carlen, P. (2013). New discourses of justification and reform for women's imprisonment in England. In P. Carlen (Ed.), Women and punishment: The struggle for justice (pp. 220-236). New York: Routledge.

Carrabine, E. (2004). Power, Discourse, and Resistance: A Genealogy of the Strangeways Prison Riot. London: Ashgate.

Carrabine, E. (2005). Prison riots, social order and the problem of legitimacy. British Journal of Criminology, 45(6), 896-913.

Castells, M. (2013). Communication Power. Oxford: Oxford University Press.

Cavise, L. L. (1998). Prisons for profit. UNESCO Courier, 51(6), 20-23.

Chakravartty, P., \& Schiller, D. (2010). Neoliberal Newspeak and Digital Capitalism in Crisis. International Journal of Communication, 4, 670-692.

Chapman, K., \& Johnston, K. (2012, July 06). Corrections minister backs private prison operator. Stuff. Retrieved from www.nzherald.co.nz

Cheliotis, L. K. (2010). The ambivalent consequences of visibility: Crime and prisons in the mass media. Crime, Media, Culture, 6(2), 169-184.

Cheng, D. (2010, February 10). Staff confront minister over private jails. New Zealand Herald. Retrieved from www.nzherald.co.nz

Chermak, S. (1995). Victims in the news: Crime and the American news media. Boulder, CO: Westview Press.

Chermak, S. (1997). The presentation of drugs in the news media: The news sources involved in the construction of social problems. Justice Quarterly, 14(4), 687718.

Chibnall, S. (1977). Law and Order News. London: Tavistock.

Chilton, P. (1987). Metaphor, euphemism and the militarization of language. Current Research on Peace and Violence, 10(1), 7-19.

Chiricos, T., Eschholz, S., \& Gertz, M. (1997). Crime, news and fear of crime: Toward an identification of audience effects. Social Problems, 44(3), 342-357.

Chouliaraki, L. (2006). The spectatorship of suffering. London: Sage.

Christian, H. (2015, September 03). Prison assault data disputed. New Zealand Herald. Retrieved from www.nzherald.co.nz

Christie, N. (1986). The Ideal Victim. In E. A. Fattah (Ed.), From Crime Policy to Victim Policy (pp. 17-30). London: The Macmillan Press.

Clarke, J., \& Newman, J. (1997). The Managerial State. London: Sage.

Cohen, S. (2002). Folk Devils and Moral Panics: The Creation of the Mods and Rockers. London: Routledge.

Cohen, S. (2013). States of denial: Knowing about atrocities and suffering. Cambridge: Polity Press.

Collins, J. (2015, July 26). Are the Gangs running our prisons? Stuff. Retrieved from www.stuff.co.nz 
Collins, S. (2011, August 02). Official nod makes Wiri biggest prison precinct. New Zealand Herald. Retrieved from www.nzherald.co.nz

Collins, S. (2013, August 07). New jail bring jobs boost. New Zealand Herald. Retrieved from www.nzherald.co.nz

Collins, S. (2015, May 06). Helping prisoners to come out of the mist. New Zealand Herald. Retrieved from www.nzherald.co.nz

Colmar Brunton. (2013). Public perceptions of crime - survey report. Retrieved from www.justice.govt.nz

Comrie, M. (2012). Politics, power and political journalists. In M. Hirst, S. Phelan, \& V. Rupar (Eds.), Scooped: The politics and power of journalism in Aotearoa, New Zealand (pp. 114-128). Auckland: AUT Media.

Corrections Association of New Zealand. (2009). Submission on Corrections (Contract Management of Prisons) Amendment Bill. Retrieved from www.parliament.nz

Courtney, B. (2014, January 18). Dotcom winning public over. Stuff. Retrieved from www.stuff.co.nz

Cowlishaw, S. (2015, August 30). 'International embarrassment' as foreign inmate bashed in troubled prison. Stuff. Retrieved from www.stuff.co.nz

Coxhead, C. (2005). Maori, crime and the media: The association of Maori with crime through media eyes. Yearbook of New Zealand Jurisprudence, 8(2), 264-299.

Crelinsten, R. D., \& Schmid, A. P. (1993). The politics of pain: Torturers and their masters. Boulder, CO: Westview.

Crewe, B., Liebling, A., \& Hulley, S. (2014). Heavy-light, absent-present: rethinking the 'weight'of imprisonment. The British Journal of Sociology, 65(3), 387410.

Cunningham, B. (2003). Re-thinking objectivity. Columbia Journalism Review, 42(2), 24-32.

Curran, J. (2002). Media and Power. London: Routledge.

Dastgheib, S. (2015, July 24). Serco prisoners live in fear of violence. Stuff. Retrieved from www.stuff.co.nz

Davis, A. (2000). Public relations, news production and changing patterns of source access in the British national media. Media, Culture \& Society, 22(1), 39-59.

Davis, A. (2007). The Mediation of Power: A Critical Introduction. New York: Routledge.

Davis, A. (2009). Journalist-source relations, mediated reflexivity and the politics of politics. Journalism studies, 10(2), 204-219.

Davison, I. (2012, December 06). League tables advocated for nation's jails. New Zealand Herald. Retrieved from www.nzherald.co.nz

Davison, I. (2012, July 06). Private firm missing its prison targets for Mt Eden. New Zealand Herald. Retrieved from www.nzherald.co.nz

Davison, I. (2013, March 27). Private prison gets a ratings tick. New Zealand Herald. Retrieved from www.nzherald.co.nz

Davison, I. (2015, July 22). Inmate died from abuse not illness, claims MP. New Zealand Herald. Retrieved from www.nzherald.co.nz

Davison, I. (2016, June 02). Soaring cost of our prisons - $\$ 900 \mathrm{~m}$ per year. New Zealand Herald. Retrieved from www.nzherald.co.nz

De Giorgi, A. (2006). Re-thinking the political economy of punishment: Perspectives on post-Fordism and penal politics. Burlington, VT: Ashgate Publishing, Ltd.

Department of Corrections. (2016a). Annual Report: 1 July 2015 - 30 June 2016. Retrieved from www.corrections.govt.nz 
Department of Corrections. (2016b). Rehabilitation programmes. Retrieved from www.corrections.govt.nz

Department of Corrections. (2016c). Trends in the Offender Population 2014/15. Retrieved from www.corrections.govt.nz

Deuze, M. (2005). What is journalism? Professional identity and ideology of journalists reconsidered. Journalism, 6(4), 442-464.

Dinsdale, M. (2011, October 11). Houdini Escapes Again. New Zealand Herald. Retrieved from www.nzherald.co.nz

Dolovich, S. (2004). Legitimate Punishment in Liberal Democracy. Buffalo Criminal Law Review, 7(2), 307-442.

Dolovich, S. (2009). How Privatization Thinks: The Case of Prisons. In J. Freeman \& M. Minow (Eds.), Government by Contract: Outsourcing and American Democracy (pp. 128-147). Cambridge: Harvard University Press.

Douglas, M. (1986). How institutions think. Syracuse, NY: Syracuse University Press.

Douzinas, C. (2007). Human rights and empire: the political philosophy of cosmopolitanism. New York: Routledge-Cavendish.

Drake, D. H. (2011). The 'dangerous other'in maximum-security prisons. Criminology \& Criminal Justice, 11(4), 367-382.

Drake, D. H., \& Henley, A. J. (2014). 'Victims' Versus 'Offenders' in British Political Discourse: The Construction of a False Dichotomy. The Howard Journal of Criminal Justice, 53(2), 141-157.

Edge, K. (2011, October 20). Escaper cuffed Houdini is back in the dock. New Zealand Herald. Retrieved from www.nzherald.co.nz

Edge, K. (2015, July 28). Give compo for killer to kids: victim's family. New Zealand Herald. Retrieved from www.nzherald.co.nz

Entman, R. M. (1993). Framing: Toward clarification of a fractured paradigm. Journal of communication, 43(4), 51-58.

Entman, R. M. (2004). Projections of power: Framing news, public opinion, and US foreign policy: University of Chicago Press.

Ericson, R. V., Baranek, P. M., \& Chan, J. B. (1987). Visualizing deviance: A study of news organization. Milton Keynes: Open University Press.

Fairclough, N. (1992). Discourse and Social Change. Cambridge: Polity Press.

Fairclough, N. (1998). Political discourse in the media: An analytical framework. In A. Bell \& P. Garrett (Eds.), Approaches to Media Discourse (pp. 142-162). Oxford: Blackwell.

Fairclough, N. (2013). Critical Discourse Analysis: The Critical Study of Language (2nd ed.). New York: Routledge.

Fairclough, N., \& Wodak, R. (1997). Critical Discourse Analysis. In T. A. Van Dijk (Ed.), Discourse as Social Interaction (pp. 258-285). London: Sage.

Faulkner, D. (2006). Crime, State and Citizen: A Field Full of Folk (2nd ed.). Winchester, UK: Waterside Press.

Feeley, M. M., \& Simon, J. (1992). The new penology: Notes on the emerging strategy of corrections and its implications. Criminology, 30(4), 449-474.

Feeley, M. M., \& Simon, J. (1994). Actuarial justice: The emerging new criminal law. In D. Nelken (Ed.), The Futures of Criminology (pp. 173-201). London: Sage.

Ferrell, J. (2013). Cultural criminology and the politics of meaning. Critical Criminology, 21(3), 257-271.

Fisher, D. (2015, August 28). Serco failed to report assault. New Zealand Herald. Retrieved from www.nzherald.co.nz 
Fisher, D. (2015, July 22). Revealed: victim at centre of jail 'bashing'. New Zealand Herald. Retrieved from www.nzherald.co.nz

Fisher, D. (2015, July 25). Ex-con: Jail economy rife in Mt Eden New Zealand Herald. Retrieved from www.nzherald.co.nz

Fishman, M. (1988). Manufacturing the news. Austin, Texas: University of Texas Press.

Fitzharris, A. (2016a). Chief Inspector's Report into the: Circumstances surrounding organised prisoner on prisoner fighting (Fight Club) and access to cell phones and contraband at Mount Eden Corrections Facility (MECF). Retrieved from www.corrections.govt.nz

Fitzharris, A. (2016b). Chief Inspector's Phase Two Report into: Circumstances surrounding organised prisoner on prisoner fighting (Fight Club) and access to cell phone contraband in New Zealand prisons other than Mount Eden Corrections Facility (MECF). Retrieved from www.corrections.govt.nz

Fitzharris, A. (2016c). Phase One Report Recommendation Status. Retrieved from www.corrections.govt.nz.

Forsythe, W. J. (1987). The Reform of Prisoners 1830-1900. London: Croom Helm. Foucault, M. (1972). The Archeology of Knowledge. London: Tavistock.

Foucault, M. (1977). Discipline and Punish: The Birth of the Prison. New York: Vintage.

Foucault, M. (1980a). Power/knowledge: Selected interviews and other writings, 1972-1977 (C. Gordon, L. Marshall, J. Mepham, \& K. Soper, Trans. C. Gordon Ed.). New York: Vintage Books.

Foucault, M. (1980b). Truth and Power (C. Gordon, L. Marshall, J. Mepham, \& K. Soper, Trans.). In C. Gordon (Ed.), Power/Knowledge: Selected Interviews and Other Writings 1972-1977 (pp. 109-133). New York: Pantheon Books.

Foucault, M. (1980c). Two Lectures (C. Gordon, L. Marshall, J. Mepham, \& K. Soper, Trans.). In C. Gordon (Ed.), Power/Knowledge: Selected Interviews and Other Writings 1972-1977 (pp. 77-108). New York: Pantheon Books.

Foucault, M. (1991). Politics and the Study of Discourse. In G. Burchell, C. Gordon, \& P. Miller (Eds.), The Foucault effect: Studies in governmentality with two lectures by and an interview with Michel Foucault (pp. 53-72). Chicago: University of Chicago Press.

Fowler, R., Hodge, R., Kress, G., \& Trew, T. (1979). Language and control. London: Routledge \& K. Paul.

Freudenburg, W. R., \& Alario, M. (2007). Weapons of Mass Distraction: Magicianship, Misdirection, and the Dark Side of Legitimation. Sociological Forum, 22(2), 146-173.

Frosh, P., \& Pinchevski, A. (2009). Media Witnessing: Testimony in the Age of Mass Communication. New York: Palgrace Macmillan.

Fuchs, C. (2009a). A contribution to theoretical foundations of critical media and communication studies. Javnost-The Public, 16(2), 5-24.

Fuchs, C. (2009b). Grounding Critical Communication Studies: An Inquiry Into the Communication Theory of Karl Marx. Journal of Communication Inquiry, $34(1), 15-41$.

Fuchs, C. (2011). Foundations of critical media and information studies. London: Routledge.

G4S Australia Pty Ltd. (2009). Submission by G4S Australia Pty Ltd to the Law and Order Committee on The Corrections (Contract Management of Prisons) Amendment Bill. Retrieved from www.parliament.nz 
Gamson, W. A., Croteau, D., Hoynes, W., \& Sasson, T. (1992). Media images and the social construction of reality. Annual review of sociology, 18, 373-393.

Gans, H. J. (1999). Deciding what's news. In H. Tumber (Ed.), News: A reader (pp. 235-248). Oxford: Oxford University Press.

Garland, D. (2001). The culture of control: Crime and social order in contemporary society. Oxford: Oxford University Press.

Geddis, A. (2009). The comparative irrelevance of the NZBORA to legislative practice. New Zealand Universities Law Review, 23(4), 465-493.

GEO Group Australia Pty Ltd. (2009). Public Submission to Law and Order Select Committee. Retrieved from www.parliament.nz

Gibson, A. (2010, August 11a). Drop-off forecast unless big projects fast-tracked. New Zealand Herald. Retrieved from www.nzherald.co.nz

Gibson, A. (2010, August 11b). 'No gas in the private tank'. New Zealand Herald. Retrieved from www.nzherald.co.nz

Gibson, A. (2012, April 21). Project could rescue building industry `on its knees'. New Zealand Herald. Retrieved from www.nzherald.co.nz

Gibson, A. (2014, March 11). Country's biggest new prison looking for staff. New Zealand Herald. Retrieved from www.nzherald.co.nz

Gibson, A. (2014, September 27). Fletcher bid to be part of city's $\$ 4.9 \mathrm{~b}$ build boom. New Zealand Herald. Retrieved from www.nzherald.co.nz

Gies, L. (2015). Mediating Human Rights: Media, Culture and the Human Rights Act. New York: Routledge.

Gilbert, J., \& Elley, B. (2013). Evaluating the Pathway: An Evaluation of the Pathway Total Reintegration Strategy undertaken by Pathway Charitable Group. Retrieved from www.howardleague.org.nz

Gladwin, J. (2009). Submission on Corrections (Contract Management of Prisons) Amendment Bill. Retrieved from www.parliament.nz

Glaser, B. G., \& Strauss, A. L. (2009). The Discovery of Grounded Theory: Strategies for Qualitative Research. London: Transaction Publishers.

Golant, B. D., \& Sillince, J. A. (2007). The constitution of organizational legitimacy: A narrative perspective. Organization studies, 28(8), 1149-1167.

Gower, P. (2009, November 02). `Crusher' Collins a self-styled tough act. New Zealand Herald. Retrieved from www.nzherald.co.nz

Gower, P. (2009, September 24). Prisons given two-to-a-cell ultimatum. New Zealand Herald. Retrieved from www.nzherald.co.nz

Gregor, K. (2010, May 04). \$41m for public-private fund. New Zealand Herald. Retrieved from www.nzherald.co.nz

Grey, S., \& de Roo, K. (2010). When the next step is capital punishment what choices do we have: Penal reform movements in the age of penal populism. New Zealand Sociology, 25(2), 38.

Grey, S., \& Sedgwick, C. (2013). The Contract State and Constrained Democracy: the community and voluntary sector under threat. Policy Quartlery, 9(3), 3-10.

Gulliver, A. (2015, July 25). Government takes over Mt Eden prison after assault allegations. Stuff. Retrieved from www.stuff.co.nz

Hall, G. (2014, September 11). Public-private projects get nod. New Zealand Herald. Retrieved from www.nzherald.co.nz

Hall, S., Critcher, C., Jefferson, T., Clarke, J., \& Roberts, B. (1978). Policing the crisis: Mugging, the state and law and order. Basingstoke: Palgrave Macmillan. 
Hallahan, K. (1999). Seven models of framing: Implications for public relations. Journal of public relations research, 11(3), 205-242.

Hallin, D. C. (1984). The media, the war in Vietnam, and political support: A critique of the thesis of an oppositional media. The Journal of Politics, 46(01), 1-24.

Hallin, D. C. (1989). The uncensored war: The media and Vietnam. New York: Oxford University Press.

Hallin, D. C. (1994). We keep America on top of the world: Television journalism and the public sphere. London: Routledge.

Hardy, C., \& Phillips, N. (1998). Strategies of engagement: Lessons from the critical examination of collaboration and conflict in an interorganizational domain. Organization science, 9(2), 217-230.

Hardy, C., \& Phillips, N. (1999). No joking matter: Discursive struggle in the Canadian refugee system. Organization studies, 20(1), 1-24.

Harris, F. (1932). Presentation of crime in newspapers: a study of methods in newspaper research. Minneapolis: The Sociological Press.

Harris, H. (2001). Content analysis of secondary data: A study of courage in managerial decision making. Journal of Business Ethics, 34(3-4), 191-208.

Hart, G. (2010, May 27). Iwi-State enteprises - the new vogue? New Zealand Herald. Retrieved from www.nzherald.co.nz

Hellmueller, L., \& Mellado, C. (2015). Professional roles and news construction: a media sociology conceptualization of journalists' role conception and performance. Communication \& Society, 28(3), 1-11.

Herbert, S. (2006). Tangled up in blue: Conflicting paths to police legitimacy. Theoretical Criminology, 10(4), 481-504.

Herman, E. S., \& Chomsky, N. (1994). Manufacturing consent: The political economy of the mass media. London: Vintage.

Hirst, M. (2012). The cultural politics of journalism: Quotidian intellectuals and the power of media capital. In M. Hirst, S. Phelan, \& V. Rupar (Eds.), Scooped: The politics and power of journalism in Aotearoa New Zealand (pp. 48-64). Auckland: AUT Media.

Höijer, B. (2004). The discourse of global compassion: The audience and media reporting of human suffering. Media, Culture \& Society, 26(4), 513-531.

Holmes, P. (2009, March 15). Corrections Minister snookered. New Zealand Herald. Retrieved from www.nzherald.co.nz

Horkheimer, M., \& Adorno, T. (2006). The Culture Industry: Enlightenment as Mass Deception. In M. G. Durham \& D. M. Kellner (Eds.), Media and cultural studies: Keyworks (pp. 41-72). Oxford: Blackwell Publishing.

Hosking, M. (2015, July 02). Govt boldly refuses to go down wondering. New Zealand Herald. Retrieved from www.nzherald.co.nz

Hough, M., \& Roberts, J. V. (2004). Youth crime and youth justice: Public opinion in England and Wales. Bristol: Policy Press.

Howard League for Penal Reform. (2009). Submission on the Corrections (Contract Management of Prisons) Amendment Bill. Retrieved from www.parliament.nz

Howe, J. (2015, July 22). Prisoners have a choice about their futures. Stuff. Retrieved from www.stuff.co.nz

Hudson, B. (2001). Punishment, rights and difference: defending justice in the risk society. In K. Stenson \& R. R. Sullivan (Eds.), Crime, risk and justice: The politics of crime control in liberal democracies (pp. 144-172). Devon: Willan.

Hudson, B. (2003). Justice in the Risk Society: Challenging and Re-affirming 'Justice' in Late Modernity. London: Sage. 
Hudson, B. (2006). Punishing monsters, judging aliens: Justice at the borders of community. Australian \& New Zealand Journal of Criminology, 39(2), 232247.

Human Rights Commission. (2009). Submission of the Human Rights Commission on Corrections (Contract Management of Prisons Amendment) Bill Retrieved from www.parliament.nz

Humpage, L. (2014). Policy change, public attitudes and social citizenship: Does neoliberalism matter? Bristol, UK: Policy Press.

Humphreys, L. (2012, November 26). Closing jail appears to end career. Stuff. Retrieved from www.stuff.co.nz

Hunt, G. (2010, August 11a). Fund gets ready for PPP projects. New Zealand Herald. Retrieved from www.nzherald.co.nz

Hunt, G. (2010, August 11b). Iwi wants a slice of the action. New Zealand Herald. Retrieved from www.nzherald.co.nz

Hurrelmann, A., Krell- Laluhová, Z., Nullmeier, F., Schneider, S., \& Wiesner, A. (2009). Why the democratic nation- state is still legitimate: A study of media discourses. European Journal of Political Research, 48(4), 483-515.

Indermaur, D. (2008). Dealing the Public In: Challenges for a Transparent and Accountable Sentencing Policy. In A. Freiberg \& K. Gelb (Eds.), Penal populism, sentencing councils and sentencing policy (pp. 45-82). Sydney: Hawkins Press.

International Council on Human Rights Policy. (2002). Journalism, Media and the Challenge of Human Rights Reporting. Retrieved from Geneva, Switzerland:

Iyengar, S., \& Kinder, D. R. (2010). News that matters: Television and American opinion. Chicago: University of Chicago Press.

Jackson, D. (1995). Destroying the Baby in Themselves: Why did the two boys kill James Bulger? London: Mushroom Publications.

Jamieson, R., \& McEvoy, K. (2005). State crime by proxy and juridical othering. British Journal of Criminology, 45(4), 504-527.

Jenkins, P. (1994). Using murder: The social construction of serial homicide. New Brunswick: AldineTransaction Publishers.

Jennings, W. G., Piquero, A. R., \& Reingle, J. M. (2012). On the overlap between victimization and offending: A review of the literature. Aggression and Violent Behavior, 17(1), 16-26.

Jewkes, Y. (2013). Creating a stir? Prisons, popular media and the power to reform. In P. Mason (Ed.), Captured by the Media: Prison Discourse in Popular Culture (pp. 137-153). New York: Routledge.

Jewkes, Y. (2015). Media and Crime. London: Sage.

Johnson, C. (2012, February 12). Prisoners denied mental health medication. New Zealand Herald. Retrieved from www.nzherald.co.nz

Johnston, K. (2012, July 06). Mt Eden Prison operator's need to improve. Stuff. Retrieved from www.stuff.co.nz

Jones, B. (2013, November 05). Did you hear the about the bishop ... ? New Zealand Herald. Retrieved from www.nzherald.co.nz

Jones, N. (2015, August 26). Serco officer 'gave tips on how to fight'. New Zealand Herald. Retrieved from www.nzherald.co.nz

Jones, N., \& Young, A. (2016, October 18). Tax cuts could be affected by $\$ 2.5$ b plan for more prison beds. New Zealand Herald. Retrieved from www.nzherald.co.nz 
Joye, S. (2009). The hierarchy of global suffering: A critical discourse analysis of television news reporting on foreign natural disasters. Journal of International Communication, 15(2), 45-61.

Joye, S. (2010). News discourses on distant suffering: a Critical Discourse Analysis of the 2003 SARS outbreak. Discourse \& Society, 21(5), 586-601.

Joye, S. (2015). Domesticating distant suffering: How can news media discursively invite the audience to care? International Communication Gazette, 77(7), 682694.

Justice Action. (2009). Submission on Corrections (Contract Management of Prisons) Amendment Bill. Retrieved from www.parliament.nz

JustSpeak. (2014). Unlocking Prisons: How we can improve New Zealand's prison system Retrieved from www.hrc.co.nz

Kelsey, J. (2009). Submission on the Corrections (Contract Management of Prisons) Bill 2009. Retrieved from www.parliament.nz

Kelsey, J. (2010, August 26). The folly of using private companies for public services. New Zealand Herald. Retrieved from www.nzherald.co.nz

Kightley, O. (2015, July 26). Oscar Kightley: Prisons are not a business. Stuff. Retrieved from www.stuff.co.nz

King, A. (1986). Sex, Money and Power. In R. Hodder-Williams \& J. Ceaser (Eds.), Politics in Britain and the United States: Comparative Perspectives (pp. 173222). Duke University Press: Durham, NC.

Kirk, S. (2015, July 19). NZ prison 'fight club' footage review widened: Corrections Minister. Stuff. Retrieved from www.stuff.co.nz

Kitch, C. L., \& Hume, J. (2008). Journalism in a Culture of Grief. New York: Routledge.

Klotz, A. (1995). Norms reconstituting interests: global racial equality and US sanctions against South Africa. International organization, 49(3), 451-478.

Lazarus, L. (2004). Contrasting Prisoners' Rights: A Comparative Examination of Germany and England. Oxford: Oxford University Press.

Leadbeater, M. (2009). Submission on the Corrections (Contract Management of Prisons) Amendment Bill.

Leask, A. (2012, April 07). Easter Bunny will Skip Petricevic's jail cell. New Zealand Herald. Retrieved from www.nzherald.co.nz

Leask, A. (2015, July 29). Ex-prison guard in drugs probe. New Zealand Herald. Retrieved from www.nzherald.co.nz

Leslie, D. (2016, October 18). Govt to spend \$1b boosting prison bed numbers. Radio New Zealand. Retrieved from www.radionz.co.nz

Lewis, J. M. W., Williams, A., Franklin, R. A., Thomas, J., \& Mosdell, N. A. (2008). The quality and independence of British journalism.

Liebling, A. (2004). Prisons and Their Moral Performance: A Study of Values, Quality and Prison Life. Oxford: Oxford University Press.

Liebling, A. (2011). Distinctions and distinctiveness in the work of prison officers: Legitimacy and authority revisited. European Journal of Criminology, 8(6), 484-499.

Little, P. (2015, December 06). Paul Litte: Treatment of prisoners is criminal. New Zealand Herald. Retrieved from www.nzherald.co.nz

Loader, I. (2007). The Cultural Lives of Security and Rights. In B. J. Goold \& L. Lazarus (Eds.), Security and Human Rights (pp. 27-44). Portland, OR: Hart Publishing. 
Loader, I., \& Mulcahy, A. (2001a). The Power of Legitimate Naming Part I - Chief Constables as Social Commentators in Post-War England. British Journal of Criminology, 41(1), 41-55.

Loader, I., \& Mulcahy, A. (2001b). The Power of Legitimate Naming Part II Making Sense of the Elite Police Voice. British Journal of Criminology, 41(2), 252-265.

Loader, I., \& Sparks, R. (2016). Ideologies and crime: political ideas and the dynamics of crime control. Global Crime, 17(3-4), 314-330.

Loren, A. (2014, September 04). Prison jobs prove popular. Stuff. Retrieved from www.stuff.co.nz

Loren, A., \& Wall, T. (2015, July 26). Father-of-three dies in violent Mt Eden prison: 'Our dad wasn't cared for'. Stuff. Retrieved from www.stuff.co.nz

Loughlin, M. (1992). Public law and political theory. Oxford: Clarendon Press.

Lukes, S. (1974). Power: A radical view. New York: Palgrave Macmillan.

Lumby, C. (2002). Televising the Invisible: Prisoners, Prison Reform and the Media. In D. Brown \& M. Wilkie (Eds.), Prisoners as Citizens: Human Rights in Australian Prisons (pp. 103-112). NSW, Australia: The Federation Press.

Maas, A. (2015, July 19). Murderer posts videos from behind bars. New Zealand Herald. Retrieved from www.nzherald.co.nz

Machin, D., \& Mayr, A. (2012). How to Do Critical Discourse Analysis: A Multimodal Introduction. London: Sage.

Marsh, H. L. (1991). A comparative analysis of crime coverage in newspapers in the United States and other countries from 1960-1989: A review of the literature. Journal of Criminal Justice, 19(1), 67-79.

Mason, P. (2006). Lies, distortion and what doesn't work: Monitoring prison stories in the British media. Crime, Media, Culture, 2(3), 251-267.

Mason, P. (2009). Crime, Media and the State. In R. Coleman, J. Sim, S. Tombs, \& D. Whyte (Eds.), State Power Crime (pp. 185-199). London: Sage Publications.

Mathiesen, T. (1974). The Politics of Abolition. London: Martin Robertson.

Matthes, J. (2007). Looking Back While Moving Forward. A Content Analysis of Media Framing Studies in the World's Leading Communication Journals, 1990-2005. Paper presented at the Mass Communication division at the 57th annual conference of the International Communication Association, San Francisco, CA, May 24-28.

Matthews, P. (2015, July 25). The week in news: Fights, feuds and Hawaiian holidays. Stuff. Retrieved from www.stuff.co.nz

Mayr, A. (2008). Language and power: An introduction to institutional discourse. New York: Continuum International Publishing Group.

McCarten, M. (2009, March 15). John Key needs to stop playing with ideology and get serious. New Zealand Herald. Retrieved from www.nzherald.co.nz

McCarten, M. (2009, November 29). National is taking NZ back down memory lane. New Zealand Herald. Retrieved from www.nzherald.co.nz

McChesney, R. W. (2004). Welcome to Havana, Mr Corleone: Issues of Media Ownership. Pacific journalism review, 10(2), 20.

McCombs, M. (2004). Setting the Agenda: The Mass Media and Public Opinion. Cambridge: Polity Press.

McCulloch, T., \& McNeill, F. (2007). Consumer society, commodification and offender management. Criminology and Criminal Justice, 7(3), 223-242. 
McGarry, R., \& Walklate, S. (2011). The Soldier as Victim: Peering through the Looking Glass. British Journal of Criminology, 51(6), 900-917.

McIvor, K. (2015, July 26). Prison violence a shameful stain. New Zealand Herald. Retrieved from www.nzherald.co.nz

McLean, J. (2013). The New Zealand Bill of Rights Act 1990 and Constitutional Propriety. New Zealand Journal of Public and International Law, 11(1), 1938.

Meng-Yee, C. (2012, July 15). 'Houdini' smashes detention cell. New Zealand Herald. Retrieved from www.nzherald.co.nz

Mills, A. (2015). A gentle thaw or continued deep freeze?: Relationships between voluntary and community organisations and the state in criminal justice in New Zealand. Third Sector Review, 21(1), 121.

Mills, H., \& Roberts, R. (2011). Is penal reform working? Community sentences and reform sector strategies. Criminal Justice Matters, 84(1), 38-41.

Mills, H., \& Roberts, R. (2012). Reducing the Numbers in Custody: Looking beyond criminal justice solutions. Retrieved from London:

Milne, J. (2015, July 26). Editorial: If we can't show decency for jail inmates, do it for their kids. Stuff. Retrieved from www.stuff.co.nz

Ministry of Justice. (2000). Re-evaluation of the Human Rights Protections in New Zealand. Retrieved from www.justice.govt.nz

Misa, T. (2009, March 16). Is privatising jails really worth the risk? New Zealand Herald. Retrieved from www.nzherald.co.nz

Moir, J. (2015, July 22). Cellphone found in Mt Eden prison search following fight club allegations. Stuff. Retrieved from www.stuff.co.nz

Moir, J. (2015, July 24). Father of Injured Mt Eden inmate says his son didn't fall, he was pushed. Stuff. Retrieved from www.stuff.co.nz

Moloney, K., Jackson, D., \& McQueen, D. (2013). News journalism and public relations: A dangerous relationship. In K. Fowler-Watt \& S. Allan (Eds.), Journalism: New Challenges (pp. 259-281). Bournemouth: Bouremouth University Centre for Journalism \& Communication Research.

Mooney, A. (2012). Human rights: Law, language and the bare human being. Language \& Communication, 32(3), 169-181.

Morgan, S. (2012, March 13). Anger at prison go-ahead. www.stuff.co.nz

Morrison, A. (2002). Objectivity. In J. McGregor \& M. Comrie (Eds.), What's news? Reclaiming journalism in New Zealand (pp. 56-72). Palmerston North: Dunmore Press Ltd.

Mosco, V. (1996). The Political Economy of Communication (2 ed.). London: Sage.

Movement for Alternatives to Prison. (2009). Submission to the Law and Order Select Committee on the Corrections (Contract Management of Prisons) Amendment Bill. Retrieved from www.parliament.nz

Moyn, S. (2010). The Last Utopia: Human Rights in History. Cambridge, MA: Harvard University Press.

Murdock, G., \& Golding, P. (1973). For a Political Economy of Mass Communications. Socialist register, 10, 205-234.

Mutua, M. W. (2001). Savages, victims, and saviors: the metaphor of human rights. Harvard International Law Journal, 42(1), 201-245.

Mutua, M. W. (2016). Is the Age of Human Rights Over? In S. McClennen, A. \& A. S. Moore (Eds.), Routledge Companion to Literature and Human Rights (pp. 450-458). New York: Routledge. 
Myllylahti, M. (2016). JMAD New Zealand media ownership report 2016. Retrieved from www.aut.ac.nz

N.A. (2015, August 27). Investigation into Mt Eden prison fights extended. Stuff. Retrieved from www.stuff.co.nz

N.A. (2015, July 22). Editorial: Prison fights point to deeper problem. Stuff. Retrieved from www.stuff.co.nz

N.A. (2015, July 27). Serco to lose more than half a million dollars for Mt Eden 'failures'. Stuff. Retrieved from www.stuff.co.nz

N.A. (2015, July 29). Editorial: Serco must be made an example of. New Zealand Herald. Retrieved from www.nzherald.co.nz

N.A. (2015, September 09). Serco facing more than \$1m in fines for Mt Eden prison failings. Stuff. Retrieved from www.stuff.co.nz

Neuman, W. R., Just, M. R., \& Crigler, A. N. (1992). Common knowledge: News and the construction of political meaning. Chicago: University of Chicago Press.

Newburn, T., \& Stanko, E. A. (1994). When men are victims: The failure of victimology. In T. Newburn \& E. A. Stanko (Eds.), Just Boys Doing Business?: Men, Masculinities and Crime (pp. 153-165). London: Routledge.

Ngā Whetü Rererangi. (2009). Submission on the Corrections (Contract Management of Prisons) Amendment Bill 2009. Retrieved from www.parliament.nz

NZME. (2015, July 19). Prison investigation to be launched after fight videos. New Zealand Herald. Retrieved from www.nzherald.co.nz

O'Malley, P. (2008). Neoliberalism and risk in criminology. In T. Anthony \& C. Cunneen (Eds.), The critical criminology companion (pp. 55-67). NSW: Hawkins Press.

O'Neill, O. (1990). Practices of Toleration. In J. Lichtenberg (Ed.), Democracy and the mass media (pp. 155-185). Cambridge: Cambridge University Press.

O'Sullivan, F. (2010, May 27). Super fund goes shopping for Kiwi businesses. New Zealand Herald. Retrieved from www.nzherald.co.nz

O'Sullivan, F. (2011, August 09). Government treads cautiously on public-private partnerships. New Zealand Herald. Retrieved from www.nzherald.co.nz

Osbome, D., \& Gaebler, T. (1993). Reinventing Government: How the Entrepreneurial Spirit is Transforming the Public Sector. New York: Plume.

Palmer, G. (2013). The Bill of Rights after twenty-one years: the New Zealand constitutional caravan moves on? New Zealand Journal of Public and International Law, 11(1), 257-280.

Pan, Z., \& Kosicki, G. M. (1993). Framing analysis: An approach to news discourse. Political communication, 10(1), 55-75.

Parker, T. (2010, March 17). Retail investors offered public-private partnership opportunity. New Zealand Herald. Retrieved from www.nzherald.co.nz

PARS. (2014). 2014 Annual Report. Retrieved from www.pars.co.nz

Peters, T. J. (1992). Liberation Management: Necessary Disorganization for the Nanosecond Nineties. A. A. Knopf: New York.

Pettit, P. (2002). Is criminal justice politically feasible? Buffalo Criminal Law Review, $5(2), 427-450$.

Phelan, S. (2014). Neoliberalism, Media and the Political: Palgrave Macmillan.

Poerksen, B. (2008). The Ideal and the Myth of Objectivity: Provocations of constructivist journalism research. Journalism studies, 9(2), 295-304.

Powers, M. (2016). A new era of human rights news? Contrasting two paradigms of human rights news-making. Journal of Human Rights, 15(3), 314-329. 
Pratt, J. (2002). Punishment and Civilization: Penal Tolerance and Intolerance in Modern Society. London: Sage.

Pratt, J. (2006). The Dark Side of Paradise Explaining New Zealand's History of High Imprisonment. British Journal of Criminology, 46(4), 541-560.

Pratt, J. (2007). Penal Populism. London: Routledge.

Pratt, J. (2008a). Penal scandal in New Zealand. In A. Freiberg \& K. Gelb (Eds.), Penal populism, sentencing councils and sentencing policy (pp. 31-44). Sydney: Hawkins Press.

Pratt, J. (2008b). When penal populism stops: Legitimacy, scandal and the power to punish in New Zealand. Australian \& New Zealand Journal of Criminology, 41(3), 364-383.

Pratt, J. (2016). Risk Control, Rights and Legitimacy in the Limited Liability State British Journal of Criminology: Advance online publication. doi: 10.1093/bjc/azw065.

Pratt, J., \& Anderson, J. (2015). 'The Beast of Blenheim', risk and the rise of the security sanction. Australian \& New Zealand Journal of Criminology, 49(4), 528-545.

Pratt, J., \& Clark, M. (2005). Penal Populism in New Zealand. Punishment \& Society, 7(3), 303-322.

Preston, P., \& Silke, H. (2011). Market 'realities': De-coding neoliberal ideology and media discourses. Australian Journal of Communication, 38(3), 47-64.

Priestley, L. (2015, July 24). Lockdown sparks court backlog. New Zealand Herald. Retrieved from www.nzherald.co.nz

Pynchon, T. (2012). Gravity's Rainbow. New York: The Penguin Press.

Radio New Zealand. (2009, July 01a). Caritas warns MP's against using private prisons managers. Radio New Zealand. Retrieved from www.radionz.co.nz

Radio New Zealand. (2009, July 01b). Public hearings on private prison management continues at Parliament. Radio New Zealand. Retrieved from www.radionz.co.nz

Radio New Zealand. (2009, May 04). Former Inmate: Privatisaing Prisons will increase reoffending. Radio New Zealand. Retrieved from www.radionz.co.nz

Radio New Zealand. (2009, November 26a). Prison. Radio New Zealand. Retrieved from www.radionz.co.nz

Radio New Zealand. (2009, November 26b). Prisons aid society says it is opposed to private prisons. Radio New Zealand. Retrieved from www.radionz.co.nz

Radio New Zealand. (2010, August 24a). ACRP contender withdraws from race. Radio New Zealand. Retrieved from www.radionz.co.nz

Radio New Zealand. (2010, August 24b). Prison advisor shocked, disappointed at company withdrawal. Radio New Zealand. Retrieved from www.radionz.co.nz

Radio New Zealand. (2010, June 03). Inmate and All Black advise private prison company. Radio New Zealand. Retrieved from www.radionz.co.nz

Radio New Zealand. (2010, June 08). Green Party criticises one of private-sector candidates to run Auckland prison. Radio New Zealand. Retrieved from www.radionz.co.nz

Radio New Zealand. (2010, May 28). Report says New Zealand prison system erodes human rights. Radio New Zealand. Retrieved from www.radionz.co.nz

Radio New Zealand. (2011, August 10). Accusations of big meals and TV's at private prison. Radio New Zealand. Retrieved from www.radionz.co.nz

Radio New Zealand. (2011, October 10). Review commissioned on Mt Eden prisoner escape. Radio New Zealand. Retrieved from www.radionz.co.nz 
Radio New Zealand (Producer). (2012, April 27). Serco falls short in crucial areas of prison management at Mt Eden during first 8 months. Retrieved from www.radionz.co.nz

Radio New Zealand (Producer). (2012, July 05). Private prison managers fall short. Retrieved from www.radionz.co.nz

Radio New Zealand (Producer). (2012, July 06). Private prison managers vow to do better. Retrieved from www.radionz.co.nz

Radio New Zealand. (2012, March 08). Private prisons no cheaper - Labour. Radio New Zealand.

Radio New Zealand (Producer). (2012, October 31). Prison Company on Track to Deliver Targets. Retrieved from www.radionz.co.nz

Radio New Zealand (Producer). (2012, September 18). Anne Tolley confident Mt Eden private prison will get better. Retrieved from www.radionz.co.nz

Radio New Zealand (Producer). (2013, March 26). Jails in Hawke's Bay, Northland, Otago ranked worst. Retrieved from www.radionz.co.nz

Radio New Zealand. (2015, December 03). Corrections hits back at critical report on teenage incarceration. Radio New Zealand. Retrieved from www.radionz.co.nz

Radio New Zealand. (2015, July 17). Corrections Minister says he's holding Serco to account over prison fights. Radio New Zealand. Retrieved from www.radionz.co.nz

Radio New Zealand. (2015, July 20). Prime Minister says prison review will be thorough. Radio New Zealand. Retrieved from www.radionz.co.nz

Radio New Zealand. (2015, July 21). Mt Eden fight clubs hard to dismiss because of video evidence - former inmate. Radio New Zealand. Retrieved from www.radionz.co.nz

Radio New Zealand. (2015, July 23). Lawyer says culture of violence and contraband reigns at Mt Eden. Radio New Zealand. Retrieved from www.radionz.co.nz

Radio New Zealand. (2015, July 27). Prison Staff. Radio New Zealand. Retrieved from www.radionz.co.nz

Reese, S. D. (2001). Framing Public Life: A Bridging Model for Media Research. In D. Reese Stephen, O. H. Gandy, \& A. E. Grant (Eds.), Framing public life: Perspectives on media and our understanding of the social world (pp. 7-31). Mahwah, NJ: Lawrence Erlbaum.

Reiner, R. (2007). Media made criminality: The representation of crime in the mass media. In M. Maguire, R. Morgan, \& R. Reiner (Eds.), The Oxford handbook of criminology (5th ed., pp. 302-337). Oxford: Oxford University Press.

Richardson, G. (1984). Time to take prisoners' rights seriously. Journal of Law and Society, 11(1), 1-32.

Richardson, G. (1985a). The Case for Prisoners' Rights. In M. Maguire, J. Vagg, \& R. Morgan (Eds.), Accountability and Prisons: Opening Up A Closed World (pp. 19-28). London: Tavistock.

Richardson, G. (1985b). Judicial Intervention In Prison Life. In M. Maguire, J. Vagg, \& R. Morgan (Eds.), Accountability and Prisons: Opening Up A Closed World (pp. 46-60). London: Tavistock.

Richardson, J. E. (2006). Analysing Newspapers: An Approach from Critical Discourse Analysis. New York: Palgrave Macmillan.

Riches, M. (2014). Constructing and Reconstructing Criminality in Aotearoa/New Zealand: Dominant Media Discourses on Crime and Criminality and their 
Impact on Offenders' Identities and Rehabilitation Efforts. (Master of Management Studies), University of Waikato.

Roper, B. S. (2011). The Fifth (Key) National Government's neoliberal policy agenda: description, analysis and critical evaluation. New Zealand Sociology, 26(1), $12-40$.

Rudman, B. (2012, March 21). Twisted economic logic for jails. New Zealand Herald. Retrieved from www.nzherald.co.nz

Rudman, B. (2015, July 29). High incarceration rate is the real prison scandal. New Zealand Herald. Retrieved from www.nzherald.co.nz

Rutherford, A. (1993). Criminal Justice and the Pursuit of Decency. Oxford: Oxford University Press.

Sachdeva, S. (2015, December 09). Serco could re-pitch for Mt Eden contract in 2017 - John Key. Stuff. Retrieved from www.stuff.co.nz

Sachdeva, S. (2016, Fenruary 15). Serco challenges Corrections Mt Eden fight club report in High Court. Stuff. Retrieved from www.stuff.co.nz

Sargeant, J. (2015, April 18). Prisons are not job creators. Stuff. Retrieved from www.stuff.co.nz

Sasson, T. (2000). William Horton's Long Shadow: 'Punitiveness' and 'Managerialism' in the penal politics of Massachusetts, 1988-99'. In T. Hope \& R. Sparks (Eds.), Crime, Risk and Insecurity: Law and Order in Everyday Life and Political Discourse (pp. 238-251). London: Routledge.

Scheufele, D. A. (1999). Framing as a theory of media effects. Journal of communication, 49(1), 103-122.

Schiller, D. (1981). Objectivity and the news: The public and the rise of commercial journalism. Philadelphia: University of Pennsylvania Press.

Schlesinger, P., \& Tumber, H. (1994). Reporting crime: The media politics of criminal justice. Oxford: Oxford University Press.

Schudson, M. (2003). The sociology of news. New York: Norton.

Scott, D. (2013). The politics of prisoner legal rights. The Howard Journal of Criminal Justice, 52(3), 233-250.

Scott, D. G. (2007). New Labour, New Legitimacy? The 'making punishment work' agenda and the limits of penal reform. In R. Roberts \& W. McMahon (Eds.), Social Justice and Criminal Justice (pp. 71-81). London: Centre for Crime and Justice Studies.

Scott, D. G. (2009). Ghosts Beyond Our Realm: A Neo-abolitionist Analvsis Of Prisoner Human Rights and Prison Officer Culture. Saarbrücken: VDM Publishing.

Scraton, P., \& Chadwick, K. (1986). Speaking Ill of the Dead: Institutionalised Responses to Deaths in Custody. Journal of Law and Society, 13(1), 93-115.

Scraton, P., \& McCulloch, J. (2009). The Violence of Incarceration: An Introduction. In J. McCulloch \& P. Scraton (Eds.), The Violence of Incarceration (pp. 1-18). New York: Routledge.

Scraton, P., Sim, J., \& Skidmore, P. (1991). Prisons Under Protest. London: Open University Press.

Semetko, H. A., \& Valkenburg, P. M. (2000). Framing European politics: A content analysis of press and television news. Journal of communication, 50(2), 93109.

Serco New Zealand Limited vs. The Chief Inspector of Corrections NZHC 1859. (2016). Retrieved from www.courtsofnz.govt.nz 
Shadwell, T. (2015, July 23). Jail 'fight club' filmed on cellphone despite multimillion-dollar jammers. Stuff. Retrieved from www.stuff.co.nz

Sharpe, M. (2012, May 08). Inmates paid out for being in jail too long. Stuff. Retrieved from www.stuff.co.nz

Sherizen, S. (1978). Social creation of crime news: All the news fitted to print. In C. Winick (Ed.), Deviance and mass media (pp. 203-224). Beverly Hills, CA: Sage.

Shichor, D. (1995). Punishment for profit: Private prisons/public concerns. Thousand Oaks, CA: Sage.

Shichor, D. (1998). Private Prisons in Perspective: Some Conceptual Isues. The Howard Journal of Criminal Justice, 37(1), 82-100.

Sigal, L. V. (1999). Reporters and officials: The organization and politics of newsmaking. In H. Tumber (Ed.), News: A reader (pp. 224-234). Oxford: Oxford University Press.

Silverstone, R. (2007). Media and morality: On the rise of the mediapolis. Cambridge: Polity Press.

Sim, J. (2008). 'An inconvenient criminological truth': pain, punishment and prison officers. In J. Bennett, B. Crewe, \& A. Wahidin (Eds.), Understanding prison staff (pp. 187-209). New York: Willan.

Simon, J. (2007). Governing through crime: How the war on crime transformed American democracy and created a culture of fear. Oxford: Oxford University Press.

Simon, J. (2014). Mass incarceration on trial: A remarkable court decision and the future of prisons in America. New York: The New Press.

Singer, N. (2012, June 16). Mapping, and Sharing, the Consumer Genome. The New York Times. Retrieved from www.nytimes.com

Skellern, G. (2009, November 11). PPP fund aims for 14pc returns. New Zealand Herald. Retrieved from www.nzherald.co.nz

Skellern, G. (2010, April 07). Craigs offers to help infrastructure investors. New Zealand Herald. Retrieved from www.nzherald.co.nz

Slade, M. (2009, July 14). PPPs 'only way' to get things done. New Zealand Herald. Retrieved from www.nzherald.co.nz

Sliwinski, S. (2011). Human Rights In Camera. Chicago: University of Chicago Press.

Smythe, D. W. (1977). Communications: Blindspot of Western Marxism. Canadian Journal of Political and Social Theory, 1(3), 1-27.

Snacken, S. (2015). Punishment, legitimate policies and values: Penal moderation, dignity and human rights. Punishment \& Society, 17(3), 397-423.

Sontag, S. (2003). Regarding the pain of others. New York: Farrar, Straus and Giroux

Sparks, R. (1994). Can Prisons Be Legitimate-Penal Politics, Privitization, and the Timeliness of an Old Idea. British Journal of Criminology, 34, 14-28.

Sparks, R. (1996). Penal 'austerity': The doctrine of less eligibility reborn? In R. Matthews \& P. Francis (Eds.), Prisons 2000 (pp. 74-93). London: Palgrave Macmillan.

Sparks, R. (2000a). 'Bringin' it All Back Home': Populism, Media Coverage and the Dynamics of Locality and Globality in the Politics of Crime Control. In K. Stenson \& R. R. Sullivan (Eds.), Crime, risk and justice: The politics of crime control in liberal democracies (pp. 194-213). London: Willan.

Sparks, R. (2000b). Risk and blame in criminal justice controversies: British press coverage and official discourse on prison security (1993-6). In M. Brown \& J. 
Pratt (Eds.), Dangerous Offenders: Punishment and Social Order (pp. 127144). London: Routledge.

Sparks, R., Bottoms, A. E., \& Hay, W. (1996). Prisons and the Problem of Order. Oxford: Oxford University Press.

Sparks, R., \& McNeill, F. (2009). Incarceration, Social Control and Human Rights. Retrieved from www.ichrp.org

Speirs, A. (2014, August 19). Prison breaks traditional mould. New Zealand Herald. Retrieved from www.nzherald.co.nz

Stammers, N. (1999). Social movements and the social construction of human rights. Human Rights Quarterly, 21(4), 980-1008.

Stanley, E. (2011). Human Rights and Prisons: A review to the Human Rights Commission. Retrieved from Auckland, Aoteaora New Zealand: www.hrc.co.nz

Stiglitz, J. E. (2011). The Media and the Crisis: An Information Theoretic Approach. In A. Schiffrin (Ed.), Bad News: How America's Business Press Missed the Story of the Century (pp. 22-36). New York: The New Press.

Suchman, M. C. (1995). Managing legitimacy: Strategic and institutional approaches. Academy of management review, 20(3), 571-610.

Supreme Court of New Zealand. (2016, September 2016). Michael Marino v The Chief Executive of the Department of Corrections [Press release]. Retrieved from www.courtsofnz.govt.nz

Surette, R. (2015). Media, crime, and criminal justice : images, realities, and policies (5th ed.). Stamford, CT: Cengage Learning.

Sutton, B., \& Norgaard, K. M. (2013). Cultures of denial: avoiding knowledge of state violations of human rights in Argentina and the United States. Sociological Forum, 28(3), 495-524.

Tait, M. (2015, July 18). Jail-fight videos upset Arthur Thomas. New Zealand Herald. Retrieved from www.nzherald.co.nz

Tankard, J. W. (2008). The empirical approach to the study of media framing. In S. D. Reese, O. H. Gandy, \& A. E. Grant (Eds.), Framing public life: Perspectives on media and our understanding of the social world (pp. 95-106). Mahway, NJ: Lawrence Arlbaum Associates, Inc,. Publishers.

Taylor, T. (2011). Changing the Prison System. Retrieved from quaker.org.nz/

Te Puni Kökiri (Ministry of Mäori Development). (2011). Addressubg the drivers of Crime for Mäori. Wellington: Te Puni Kökiri (Ministry of Mäori Development).

Thompson, J. B. (2000). Political scandal: Power and visability in the media age. Cambridge: Polity Press.

Thompson, J. B. (2005). The new visibility. Theory, Culture \& Society, 22(6), 31-51.

Thompson, L., \& Elling, R. C. (2000). Mapping patterns of support for privatization in the mass public: The case of Michigan. Public Administration Review, 60(4), 338-348.

Tresch, A. (2009). Politicians in the Media: Determinants of Legislators' Presence and Prominence in Swiss Newspapers. The International Journal of Press/Politics, 14(1), 67-90.

Trewavas, P. (2009). Submission on the Corrections (Contract Management of Prisons) Amendment Bill 2009. Retrieved from www.parliament.nz

Trotter, C. (2015, July 28). Human rights costs lot of money. Stuff. Retrieved from www.stuff.co.nz 
Tunstall, J. (1970). The Westminster Lobby Correspondents: A Sociological Study of National Political Journalism. London: Routledge and Kegan Paul.

Tyler, T. R. (2003). Procedural justice, legitimacy, and the effective rule of law. Crime and justice, 30, 283-357.

Tyler, T. R. (2006). Why People Obey the Law. New Jersey: Princeton University Press.

United Nations Human Rights Council. (2009). Universal Periodic Review of New Zealand. Retrieved from www.lib.ohchr.org

Vaara, E. (2013). Struggles of Legitimacy in Mediatized Society. Paper presented at the Connecting Rigor and Relevance in Institutional Analysis conference, Harvard Business School, June 3-4, 2013.

Vaara, E., Tienari, J., \& Laurila, J. (2006). Pulp and paper fiction: On the discursive legitimation of global industrial restructuring. Organization studies, 27(6), 789-813.

Van Dijk, T. A. (1993). Principles of critical discourse analysis. Discourse \& Society, 4(2), 249-283.

Van Dijk, T. A. (1998). Ideology: A Multidisciplinary Approach. London: Sage.

Van Dijk, T. A. (2015). Critical Discourse Analysis. In D. Tannen, H. E. Hamilton, \& D. Schiffrin (Eds.), The handbook of discourse analysis (2nd ed., pp. 466485). Chichester: John Wiley \& Sons.

Vander Laenen, F., \& Persac, N. (2014). Whose claim is legitimate anyway? Negotiating power in inter-agency collaboration. In N. Peršak (Ed.), Legitimacy and Trust in Criminal Law, Policy and Justice: Norms, Procedures, Outcomes (pp. 111-129). New York: Ashgate.

Vasiljevic, M., \& Viki, G. T. (2014). Dehumanization, moral disengagement, and public attitudes to crime and punishment In P. G. Bain, J. Vaes, \& J.-P. Leyens (Eds.), Humanness and dehumanization (pp. 129-157). New York: Psychology Press.

Vaughan, B. (2000). Punishment and conditional citizenship. Punishment \& Society, 2(1), 23-39.

Wacquant, L. (2010). Crafting the neoliberal state: Workfare, prisonfare, and social insecurity. Sociological Forum, 25(2), 197-220.

Walklate, S. (2007). Men, Victims and Crime. In P. Davies, P. Francis, \& C. Greer (Eds.), Victims, Crime and Society (pp. 142-164). London: Sage.

Waller, J. E. (2008). The ordinariness of extraordinary evil: the making of perpetrators of genocide and mass killing. In O. Jensen \& C.-C. W. Szejnmann (Eds.), Ordinary People as Mass Murderers (pp. 145-164). UK: Palgrave Macmillan.

Walters, L. (2015, July 16). Mt Eden prison fighting videos posted online. Stuff. Retrieved from www.stuff.co.nz

Watkins, T. (2015, July 21). Prisoner death claim by Labour MP Kelvin Davis over Mt Eden fight club allegations. Stuff. Retrieved from www.stuff.co.nz

Watkins, T. (2015, July 25). Corrections Minister Sam Lotu-Iiga not the only reputation shattered in prison crisis. Stuff. Retrieved from www.stuff.co.nz

Weatherall, M. (2009, August 11). Many pieces to the jigsaw. New Zealand Herald. Retrieved from www.nzherald.co.nz

Weber, M. (1946). Politics as a Vocation. In H. H. Gerth \& C. Wright Mills (Eds.), From Max Weber: Essays in Sociology (pp. 77-128). New York: Oxford University Press. 
Weber, M. (1978). Economy and society: An outline of interpretive sociology. Los Angeles, CA: University of California Press.

Welch, M., Weber, L., \& Edwards, W. (2000). "All the news that's fit to print": a content analysis of the correctional debate in the New York Times. The Prison Journal, 80(3), 245-264.

Wessler, H. (2008). Public deliberation and public culture: the writings of Bernhard Peters, 1993-2005 (H. Wessler Ed.). New York: Palgrave MacMacmillan.

Whitty, N. (2010). Rights as risk: managing human rights and risk in the UK prison sector. London: Centre for Analysis of Risk and Regulation, London School of Economics and Political Science.

Wilke, C. (2007). Recognizing Victimhood: Politics and Narratives of Rehabilitation in Germany. Journal of Human Rights, 6(4), 479-496.

Wilson, D., \& O'Sullivan, S. (2004). Images of incarceration: Representations of prison in film and television drama. Winchestor, UK: Waterside Press.

Wimmer, R. D., \& Dominick, J. R. (1994). Mass Media Research: An Introduction (10 ed.). Belmont, CA: Wadswroth.

Wodak, R. (2009). The discourse of politics in action: Politics as usual. New York: Palgrave Macmillan.

Wolfsfeld, G. (1997). Media and political conflict: News from the Middle East. New York: Cambridge University Press.

Wood, J. K. (2005). In whose name? Crime victim policy and the punishing power of protection. NWSA Journal, 17(3), 1-17.

Zelizer, B. (2010). About to die: How news images move the public. New York: Oxford University Press.

Zimring, F. E., \& Hawkins, G. (1994). The Growth of Imprisonment in California. The British Journal of Criminology, 34, 83-96. 